RENATA KURUSU GANCEV

\title{
CONCENTRAÇÃO DE BAUXITA POR FLOTAÇÃO REVERSA
}

\author{
Dissertação apresentada à Escola \\ Politécnica da Universidade de São \\ Paulo para obtenção do título de \\ Mestre em Engenharia
}


RENATA KURUSU GANCEV

\title{
CONCENTRAÇÃO DE BAUXITA POR FLOTAÇÃO REVERSA
}

\author{
Dissertação apresentada à Escola \\ Politécnica da Universidade de São \\ Paulo para obtenção do título de \\ Mestre em Engenharia \\ Área de Concentração: \\ Engenharia Mineral \\ Orientador: \\ Prof. Dr. Arthur Pinto Chaves
}

SÃo PAULO 
Ao Boris e aos meus pais, com muito carinho E ao querido Tico "in memoriam" 


\section{AGRADECIMENTOS}

Ao Professor Dr. Arthur Pinto Chaves, pela pessoa maravilhosa que é e por ter me despertado o gosto pelo Tratamento de Minérios com seus ensinamentos.

Ao Boris, pelo amor que me inspira a cada dia.

À minha família, principalmente meus pais, pela criação, amor e por todo apoio para eu chegar até aqui.

À Companhia Brasileira de Alumínio, em nome dos Engenheiros Claret Vidal Abreu, Christian Fonseca de Andrade, Rogério Tarcia, André Luiz Fonseca e do Químico Nilson Bigogno, que foram fundamentais para a realização deste trabalho.

A toda equipe do Laboratório da CBA, pela amizade, pela ajuda na amostragem e pelos trabalhos de laboratório.

Ao professor Dr. Eldon Azevedo Masini, por toda orientação, e a toda equipe do Laboratório de Tratamento de Minérios, especialmente ao Tico “in memoriam", por toda ajuda e todo companheirismo em todos os momentos.

A toda equipe do Laboratório de Físico-Química de Interfaces da Escola Politécnica da USP, principalmente, a Ivani, pelos trabalhos de laboratório e por estar sempre disposta a ajudar.

Ao Professor Dr. Henrique Kahn e à Liz do Laboratório de Caracterização Tecnológica da Escola Politécnica da USP pela utilização dos equipamentos necessários e apoio.

Aos amigos da Escola, principalmente ao Gustavo, Tomaz, Miguel, Odair e Marisa por toda ajuda em diversas etapas deste trabalho.

A todos os professores do Departamento de Engenharia de Minas e Petróleo, que contribuíram em minha formação como Engenheira de Minas.

A todos os amigos da Multigeo. 


\section{RESUMO}

O presente trabalho propõe a concentração da bauxita presente em um rejeito fino gerado na usina de beneficiamento da Companhia Brasileira de Alumínio (CBA), agora denominada Votorantim Metais Alumínio, em Itamarati de Minas (MG), através da flotação reversa da sílica, sob a forma de quartzo. Como os minerais de ferro e titânio acompanham a bauxita, é necessário fazer separação magnética para eliminá-los do concentrado final. O concentrado de ferro e titânio pode ser utilizado como aditivo para fabricação de cimento portland. O rejeito de sílica pode ser utilizado como areia para construção civil ou na própria mina em manutenção de vias de acesso. Os experimentos sistemáticos em bancada foram realizados em célula de flotação mecânica, primeiramente, com minério de uma amostragem realizada em 2004. Determinadas as dosagens ótimas dos reagentes (coletor e depressor), partiu-se para a flotação com etapas "cleaner" e "scavenger" para definir o balanço de massas e verificar o comportamento do processo. Para validar as conclusões do trabalho experimental, foi feita nova amostragem na usina de beneficiamento de Itamarati de Minas, em julho de 2005, e, com este minério, 0 experimento de flotação com recirculação de produtos em um circuito em bancada composto por cinco etapas "rougher", "cleaner" e "scavenger". Partindo-se de uma alimentação nova com $11,6 \%$ de alumina aproveitável, chegou-se a um concentrado com teor de 52,6\% no final do circuito, após a separação magnética, com recuperação em massa de 13,3\% e recuperação de alumina aproveitável de 60,4\%.

Palavras-chave: mineração sustentável. aproveitamento de rejeitos. minimização de impacto ambiental. flotação. bauxita. 


\begin{abstract}
The present work proposes bauxite concentration using quartz flotation from a product so far considered a tailing, from the ore processing plant of Companhia Brasileira de Alumínio (CBA), now called Votorantim Metais Alumínio, at Itamarati de Minas (MG). A magnetic separation operation is also necessary to eliminate iron and titanium contaminants. Both products from this beneficiation process can have an industrial destination: iron and titanium concentrate can be used as a portland cement charge and the quartz can be used as construction sand in mine or in road maintenance. Systematic experiments were performed on bench cell froth flotation using the remaining ore sample taken in a 2004 campaign. The optimum collector and depressant dosages were found, followed by a flotation test with cleaner and scavenger that determined the mass balance and confirmed the process behavior. To validate these conclusions a fresh ore sample was taken in July 2005. A new simulation of the flotation circuit by locked cycle with five steps rougher, cleaner and scavenger in bench scale was done with this sample. From an 11,6\% alumina feed, a $52 \% \mathrm{Al}_{2} \mathrm{O}_{3}$ alumina concentrate was achieved, after magnetic separation. The mass recovery was $13,3 \%$ and the available alumina recovery was $60,4 \%$
\end{abstract}

Keywords: sustainable mining. tailing recovery. decrease of environmental impact. flotation. bauxite. 


\section{LISTA DE ILUSTRAÇÕES}

Figura 1 - Principais questões envolvidas no setor recursos minerais ..................17

Figura 2 - Etapas de fabricação do alumínio ................................................22

Figura 3 - Distribuição dos depósitos de bauxita...........................................27

Figura 4 - Províncias de depósitos lateríticos................................................28

Figura 5 - Localização regional do depósito de bauxita .......................................33

Figura 6 - Rotas de produção das aminas e seus derivados...............................35

Figura 7 - Usina de beneficiamento de Itamarati de Minas, CBA ............................38

Figura 8 - Espirais concentradoras do circuito de finos do minério anfibolítico ........40

Figura 9 - Fluxograma atual do beneficiamento em Itamarati de Minas...................41

Figura 10 - Máquina de flotação Denver ...................................................45

Figura 11 - Representação da flotação e seus produtos ......................................45

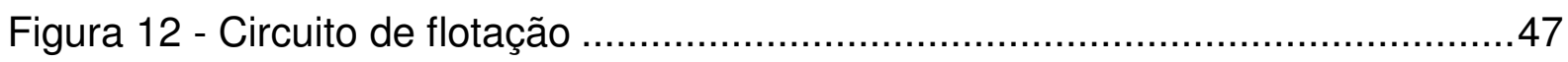

Figura 13 - Etapa "rougher" | ................................................................. 48

Figura 14 - Flotação com "cleaner" e "scavenger" ...................................................49

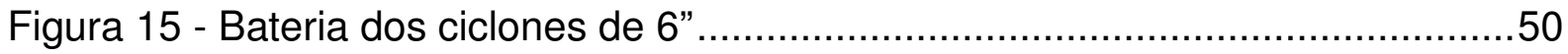

Figura 16 - Tambores com as amostras coletadas .......................................50

Figura 17 - Etapas "rougher", "cleaner" e "scavenger" da flotação reversa...............52

Figura 18 - Flotação com recirculação de produtos .........................................53

Figura 19 - Aspecto geral do UF do ciclone de 6" ...........................................64

Figura 20 - Detalhe dos grãos do UF do ciclone de 6" .....................................65

Figura 21 - Detalhe de grão misto do UF do ciclone de 6 " ...................................66

Figura 22 - Outro detalhe de grão misto do UF do ciclone de 6" ..........................66

Figura 23 - Grãos de gibsita contaminados no UF do ciclone de 6" .......................67

Figura 24 - Vista geral da amostra do UF do ciclone de 6 " ...............................67

Figura 25 - Flotado e deprimido antes da separação magnética...........................69

Figura 26 - Produtos finais da flotação reversa: flotado, deprimido magnético e não-

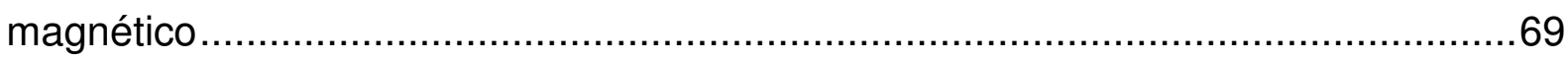

Figura 27 - Concentrado da flotação antes e após a separação magnética ............70 


\section{LISTA DE GRÁFICOS}

Gráfico 1 - Evolução da produção de alumínio primário......................................24

Gráfico 2 - Evolução do preço de alumínio primário (preço em US $\$ / t$ ) ....................25

Gráfico 3 - Recuperações e teores de alumina em função da variação da concentração de coletor 56

Gráfico 4 - Recuperações e teores de alumina em função da variação da concentração de depressor 57

Gráfico 5 - Curva granulométrica da amostra de cabeça do rejeito 62 


\section{LISTA DE TABELAS}

Tabela 1 - Produção mundial de alumínio primário ...............................................23

Tabela 2 - Produção e reservas de bauxita no mundo ........................................29

Tabela 3 - Recuperações e teores em função da dosagem de coletor .....................55

Tabela 4 - Recuperações e teores em função da dosagem de depressor ................57

Tabela 5 - Recuperações e teores para os produtos da flotação com "cleaner" e

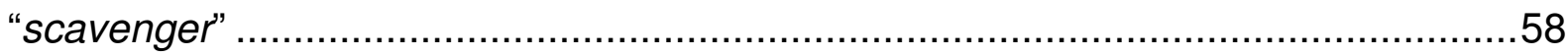

Tabela 6 - Resultados da flotação sem deslamagem.......................................59

Tabela 7 - Análise química da amostra 1 por faixa granulométrica........................60

Tabela 8 - Análise química por faixa granulométrica e da amostra de cabeça (AQC)

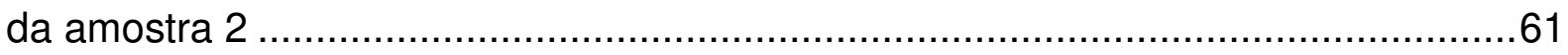

Tabela 9 - Análise granulométrica da amostra 2 ...........................................61

Tabela 10 - Resultado da análise por difratometria de raios $X \ldots \ldots \ldots \ldots \ldots \ldots \ldots \ldots \ldots . . . \ldots 3$

Tabela 11 - Resultado da análise química semiquantitativa por espectrometria de

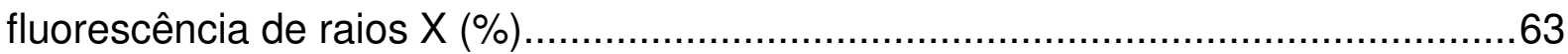

Tabela 12 - Recuperações e teores para os produtos da flotação com recirculação de produtos 


\section{LISTA DE ABREVIATURAS E SIGLAS}

$A Q C$

CBA

EPUSP

LCT

LTM

UF

Análise química de cabeça

Companhia Brasileira de Alumínio

Escola Politécnica da Universidade de São Paulo

Laboratório de Caracterização Tecnológica do Departamento de Engenharia de Minas e de Petróleo da EPUSP

Laboratório de Tratamento de Minérios e Resíduos Industriais do Departamento de Engenharia de Minas e de Petróleo da EPUSP "Underflow" 


\section{LISTA DE SÍMBOLOS}

\begin{tabular}{ll}
$\rho_{\mathrm{p}}$ & Densidade da polpa \\
$\rho_{\mathrm{s}}$ & Densidade dos sólidos \\
$\mu \mathrm{m}$ & Micrômetro \\
$\mathrm{A}$ & Alimentação da flotação \\
$\mathrm{Al}_{2} \mathrm{O}_{3 \text { apr }}$ & Alumina aproveitável \\
$\mathrm{CL}$ & Etapa "cleaner" da flotação \\
$\mathrm{D}$ & Deprimido da flotação \\
$\mathrm{DCL}$ & Deprimido da etapa "cleaner" \\
$\mathrm{DCS}$ & Deprimido da etapa "scavenger" \\
$\mathrm{D}_{\mathrm{MAG}}$ & Deprimido magnético \\
$\mathrm{D}_{\mathrm{N}-\mathrm{MAG}}$ & Deprimido não-magnético \\
$\mathrm{F}$ & Flotado da flotação \\
$\mathrm{FLCL}$ & Flotado da etapa "cleaner" \\
$\mathrm{FLSC}$ & Flotado da etapa "scavenger" \\
$\mathrm{g}$ & Grama \\
$\mathrm{ml}$ & Mililitro \\
$\mathrm{m}_{\mathrm{p}}$ & Massa de polpa \\
$\mathrm{m}_{\mathrm{s}}$ & Massa de sólidos \\
$\mathrm{R}$ & Etapa "rougher" da flotação \\
$\mathrm{RAl}_{2} \mathrm{O}_{3 a p r o v}$ & Recuperação de alumina aproveitável \\
$\mathrm{R}_{\text {massa }}$ & Recuperação em massa \\
$\mathrm{SC}$ & Etapa "scavenger" da flotação \\
$\mathrm{SiO}_{2 \text { insol }}$ & Sílica insolúvel \\
$\mathrm{SiO}_{2 \text { reat }}$ & Sílica reativa \\
$\mathrm{SiO}_{2 \text { total }}$ & Sílica total \\
$\mathrm{t}_{\mathrm{f}}$ & Tempo de flotação \\
$\mathrm{V}_{\mathrm{p}}$ & Volume de polpa \\
& \\
\hline &
\end{tabular}




\section{SUMÁRIO}

1 INTRODUÇÃO

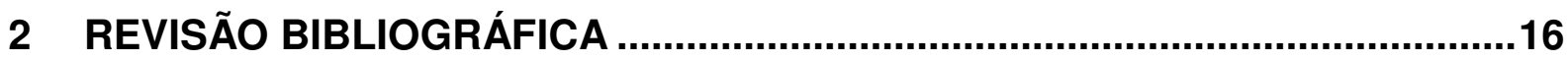

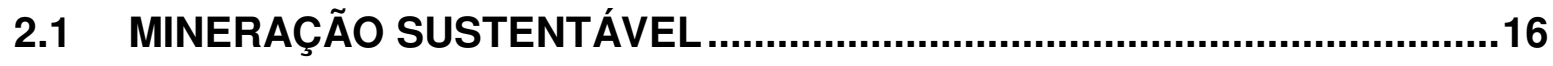

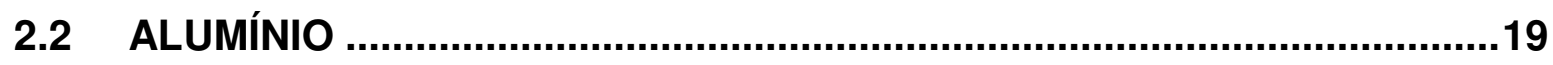

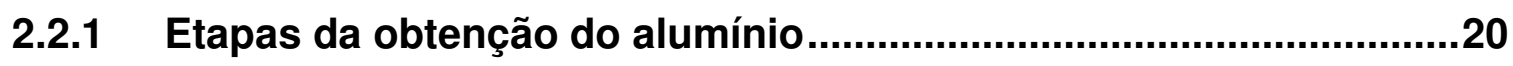

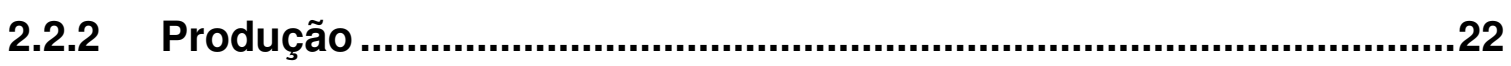

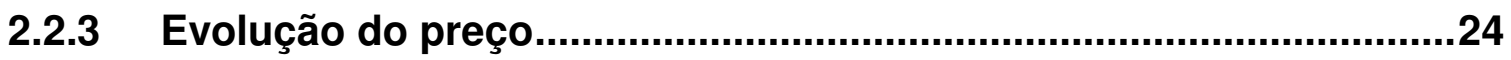

2.3 BAUXITA

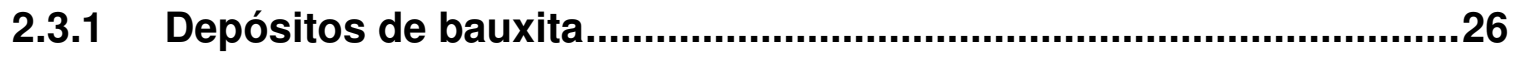

2.3.2 Produção de bauxita ....................................................................28

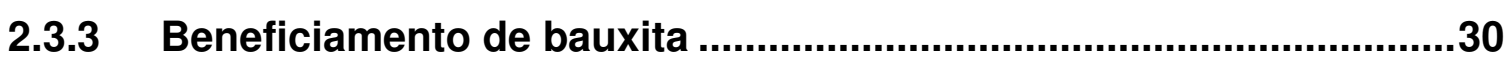

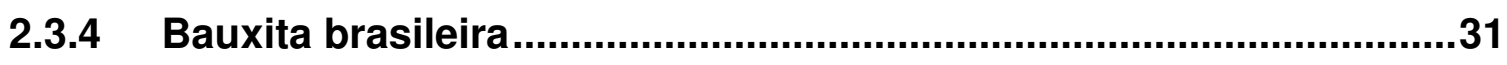

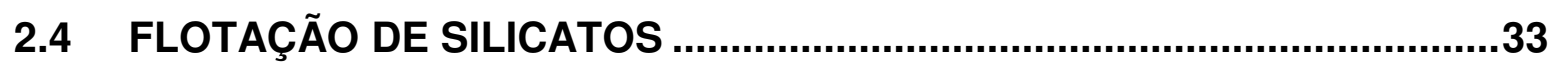

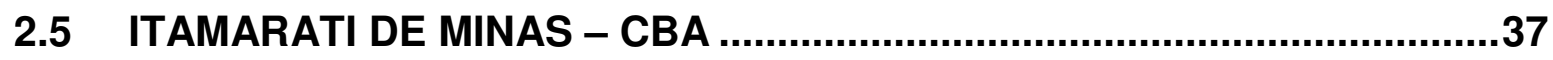

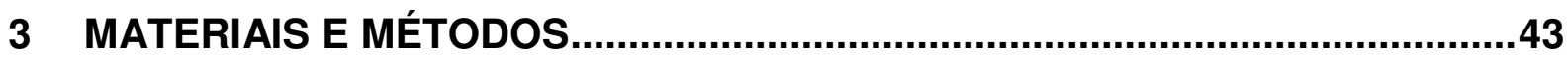

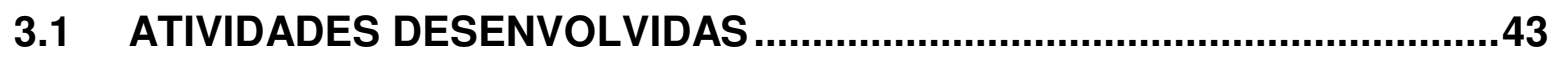

3.2 DETERMINAÇÃO DA DOSAGEM ÓTIMA DOS REAGENTES ..................46

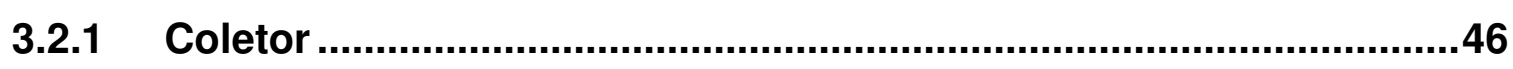

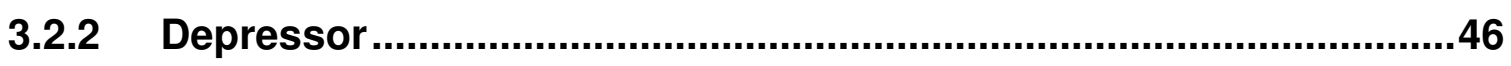

3.3 FLOTAÇÃO COM “CLEANER” E "SCAVENGER”.................................47

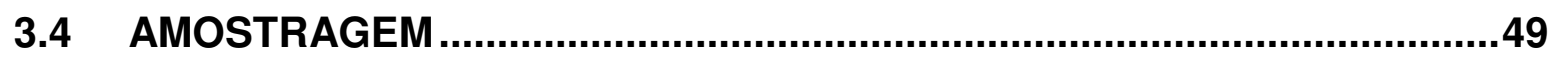

3.4.1 Preparação das amostras ................................................................

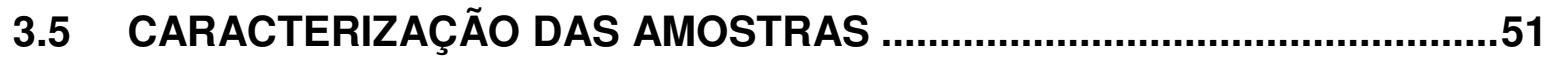

3.6 FLOTAÇÃO COM RECIRCULAÇÃO DE PRODUTOS ...............................52

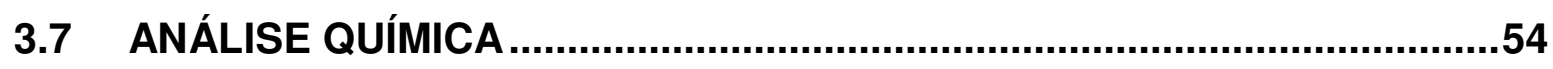

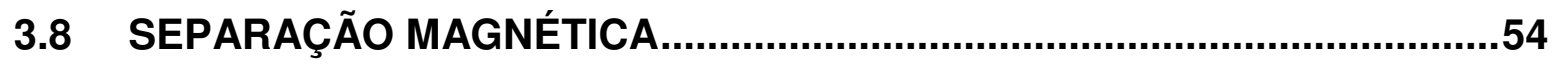

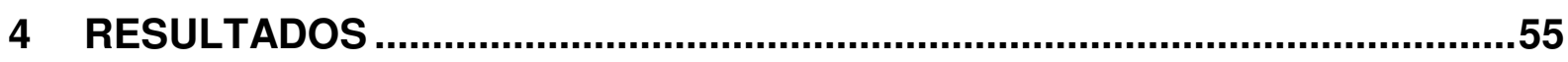

4.1 DETERMINAÇÃO DA DOSAGEM ÓTIMA DOS REAGENTES..................55

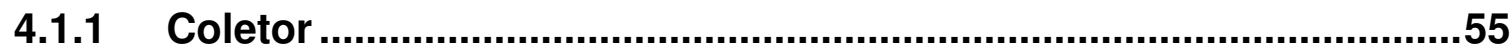

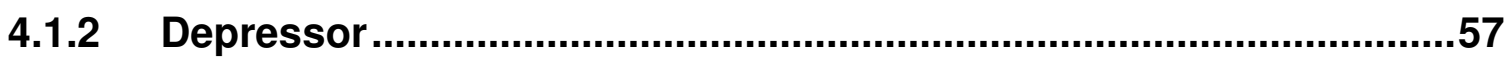


4.2 FLOTAÇÃO COM “CLEANER” E "SCAVENGER” .................................58

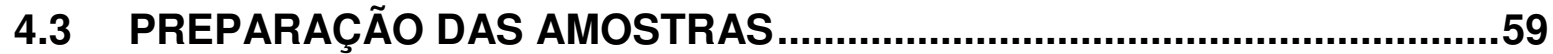

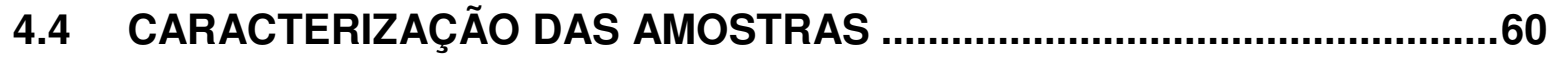

4.4.1 Microscopia eletrônica de varredura ...............................................64

4.5 FLOTAÇÃO COM RECIRCULAÇÃO DE PRODUTOS ……...........................

4.6 SEPARAÇÃO MAGNÉTICA..............................................................70

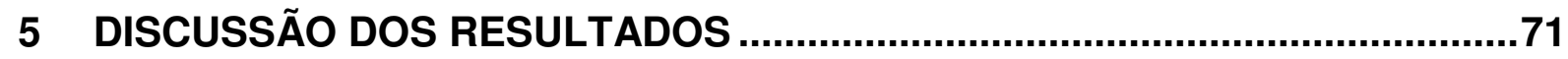

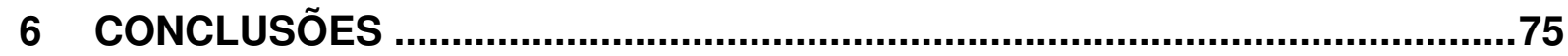

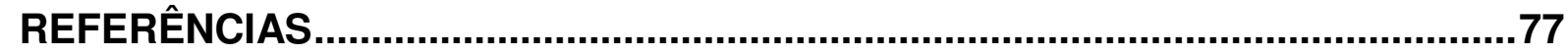

APÊNDICE A - Determinação da dosagem ótima de coletor (fluxogramas)......81 APÊNDICE B - Determinação da dosagem ótima de depressor (fluxogramas) 84 APÊNDICE C - Flotação com "cleaner" e "scavenger" (fluxogramas) ...............86

APÊNDICE D - Flotação sem deslamagem (fluxogramas) ................................88

APÊNDICE E - Flotação com recirculação de produtos (fluxograma) ................89

ANEXO A - Resultado de análise por difratometria de raios X.........................90

ANEXO B - Resultado de análise por fluorescência de raios X..........................92 


\section{INTRODUÇÃO E OBJETIVO}

Por serem os bens minerais recursos não-renováveis, sempre houve uma preocupação com a escassez conforme o aumento da população e da demanda por esses bens. Já alertava o Professor Joaquim Maia (MAIA, 1973) sobre a importância da conservação mineral para atender as futuras gerações, há mais de 30 anos. Com o passar dos anos, tem-se verificado o aumento das reservas minerais, pois novas técnicas e tecnologias permitiram melhores conhecimentos dos recursos e reservas. Além disso, as novas tecnologias contribuíram para o aumento da produtividade e da qualidade dos produtos. Essas ações fazem parte da mineração sustentável, que visa manter os estoques para as gerações futuras, reduzir os impactos ambientais da mineração e racionalizar o consumo de matérias-primas e das próprias substâncias minerais. No tratamento mineral, o aproveitamento de minérios de baixo teor e de rejeitos gerados contribui para a sustentabilidade da mineração. Como consequência destas ações, as instalações de tratamento de minérios devem trabalhar para otimizar as condições operacionais e, assim, maximizar as recuperações e os teores.

Nesta ordem de idéias está inserido o presente trabalho sobre 0 aproveitamento dos finos do beneficiamento da bauxita na unidade de Itamarati de Minas (MG) explotada pela Companhia Brasileira de Alumínio (CBA), agora Votorantim Metais Alumínio. A usina opera com dois minérios diferentes originados da laterização de diferentes tipos de rocha e constituídos essencialmente por gibsita, um de rochas gnáissicas e o outro de rochas anfibolíticas. Já foi desenvolvido o processo de aproveitamento de finos para o minério anfibolítico, cujos contaminantes são minerais de ferro e titânio, através de espirais concentradoras (BERGERMAN, 2003). O presente trabalho propõe uma nova linha para aproveitar a fração fina do minério gnáissico, rico em sílica, que não obteve recuperação viável no circuito de espirais.

O objetivo é a transformação de um rejeito em produtos, através da flotação reversa da sílica, viabilizando técnica e economicamente os resíduos gerados, aumentando a recuperação de bauxita e a vida útil da barragem de contenção de rejeitos, com o completo aproveitamento do minério. 
Para este fim foi dada continuidade ao trabalho de conclusão do curso de Engenharia de Minas da Escola Politécnica da Universidade de São Paulo desenvolvido por Tiago Guelfi de Freitas em 2004 (FREITAS, 2004), no sentido de se realizarem ensaios exploratórios para concentrar a bauxita por flotação, já que a granulometria era favorável para tal. Tentou-se inicialmente flotar a bauxita, mas os resultados não foram satisfatórios, desestimulando esta linha de trabalho. Ao contrário, a flotação reversa (da sílica) apresentou bons resultados, que foram otimizados no presente trabalho. Em complemento, foi feita uma pesquisa bibliográfica sobre o contexto envolvido e as principais propriedades e fenômenos em pauta: mineração sustentável, alumínio, bauxita, flotação de silicatos e os trabalhos já realizados na usina de beneficiamento de Itamarati de Minas visando o aproveitamento de finos.

Numa etapa preliminar haviam sido definidos o coletor Flotigam EDA (uma eteramina fornecida pela Clariant), o pH de condicionamento e flotação em torno de 10 e o depressor: solução a $2 \%$ de amido gelatinizado com soda cáustica utilizando a relação mássica de 5:1. Em seguida foram realizados experimentos sistemáticos de flotação para determinar as dosagens ótimas dos reagentes, as etapas de flotação necessárias e comparar o comportamento do sistema mediante a simulação de um circuito industrial em escala de bancada, ensaio de flotação com recirculação de produtos. Os concentrados finais foram submetidos à separação magnética dando origem aos concentrados de bauxita, produto final utilizado na fabricação de alumínio e concentrados de ferro e titânio, que podem ser utilizados como aditivos na fabricação de cimento portland. O rejeito da flotação é o flotado, sílica, composta principalmente pelo mineral quartzo e com pequenas quantidades de ferro, que pode ser utilizado como areia para a construção civil ou em obras de manutenção de vias dentro da mina. De qualquer forma, deixam de ser lançados na barragem de rejeitos os volumes correspondentes (areia, "pesados" e bauxita). A vida útil da barragem, que é uma obra civil complexa e cara, fica muito maior, diminuindo os seus custos de capital e operacional e minimizando o impacto ambiental, porque estes rejeitos foram transformados em subprodutos.

É importante salientar que, em contraposição à finalidade lucrativa principal, está o conceito social de conservação e a preservação das condições ecológicas. Estas causas foram bastante negligenciadas no início das atividades da mineração, mas com o tempo tornaram-se cada vez mais relevantes. Hoje são fundamentais. 


\section{REVISÃO BIBLIOGRÁFICA}

\subsection{MINERAÇÃo SUSTENTÁVEL}

Os minerais são essenciais à vida humana, o que faz da mineração uma atividade fundamental para o desenvolvimento econômico e social de muitos países e em especial, do Brasil, onde a indústria Extrativa Mineral representou, aproximadamente, $3 \%$ do PIB Brasil em 2008, que foi de $R \$ 2,9$ trilhões segundo dados do IBGE.

Por ser um recurso não-renovável, os bens minerais sempre despertaram uma preocupação em relação à escassez para as futuras gerações. A reflexão apresentada pelo Professor Joaquim Maia (MAIA, 1973), sobre os conceitos fundamentais do Tratamento de Minérios, já ressaltava, 36 anos atrás, a importância da conservação mineral em contraposição à finalidade lucrativa. O Professor já dizia que, para todas as finalidades práticas, o mundo mineral é um fenômeno estático e deve ser encarado como tal. As reservas comprovadas e lavráveis são relativamente escassas e a humanidade não se pode dar ao luxo de explorá-las no proveito imediato de uns poucos privilegiados.

Conforme exposto por Suslick; Machado e Ferreira (2005) os recursos minerais são finitos e as taxas de consumo aceleraram nas últimas décadas. Há incertezas na classificação de recursos e reservas minerais, e a cada ano novas pesquisas revelam recursos adicionais que ampliam o patrimônio físico dos recursos não-renováveis. Só para exemplificar, os recursos e reservas identificados de bauxita que eram de 1,4 bilhões de $t$ em 1950, aumentaram para 350 bilhões de $t$ em 2000. O mesmo ocorre para outras commodities minerais como ferro, chumbo, rocha fosfática, gás natural, óleo, carvão, entre outras. Ou seja, atualmente não há o problema de escassez para as gerações futuras, já que ela está muito mais vinculada aos aspectos econômicos do que ao esgotamento físico do mineral. Além disso, as novas tecnologias contribuem para a sustentabilidade com novas técnicas para localizar e avaliar jazidas, aumentar a produtividade e a qualidade dos 
produtos. A relação da sustentabilidade com os recursos minerais, o meio ambiente e a economia está esquematizada na figura 1.

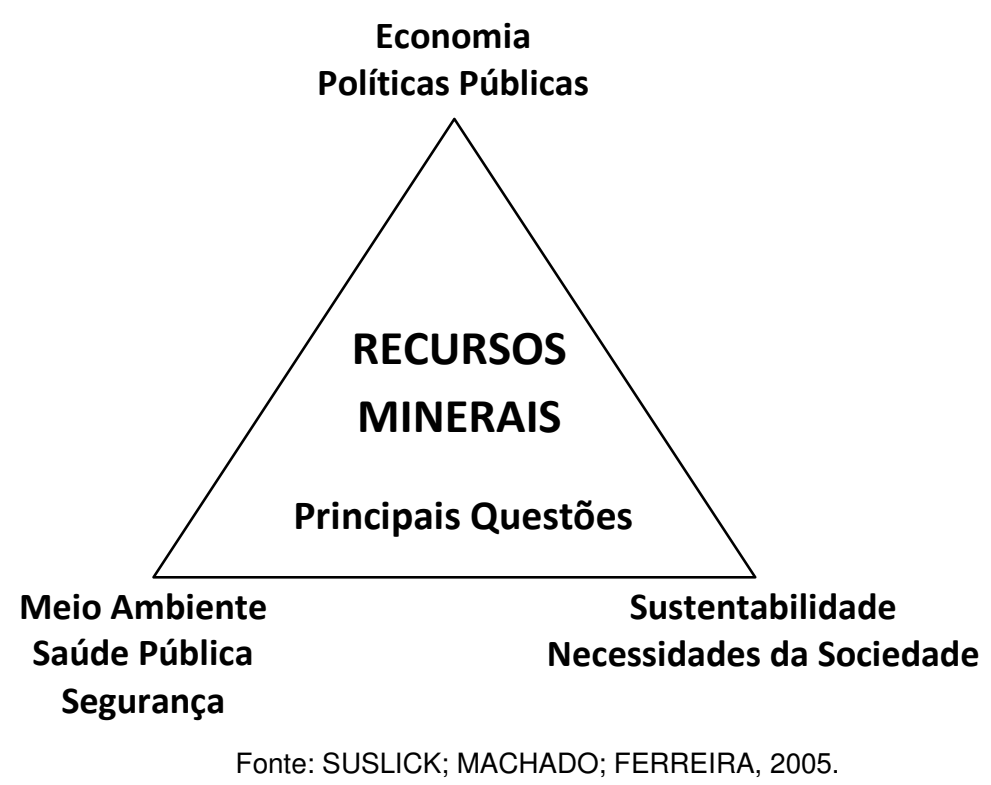

Figura 1 - Principais questões envolvidas no setor recursos minerais

A conservação e a sustentabilidade estão relacionadas da seguinte forma: "quanto mais conservamos, mais deixaremos um legado aceitável para nossos descendentes" (SUSLICK; MACHADO; FERREIRA, 2005). Sem esquecer de equilibrar o suprimento para manter as atividades econômicas e a escassez mineral.

A sustentabilidade e o conceito de preservação dos recursos minerais já fazem parte do planejamento estratégico das empresas mineradoras, visto que a legislação ambiental torna-se cada vez mais rígida nos países industrializados. A política de conservação impõe um ritmo de utilização subordinado aos interesses sociais, que é o uso prudente e inteligente. Requer que todos os recursos sejam controlados por métodos eficazes e que todo desperdício seja evitado, dando a cada material o emprego mais adequado à sua natureza.

Segundo Dias (2001, p. 80) a sustentabilidade ambiental na mineração pode ser alcançada com as seguintes ações:

- manutenção dos estoques - garantir a disponibilidade dos bens minerais através da pesquisa de novas reservas, novos métodos de prospecção e pesquisa, e novas técnicas de beneficiamento;

- redução dos impactos da produção - a qualidade do meio ambiente deve ser mantida igual ou superior, com a utilização das melhores 
práticas ambientais nos trabalhos envolvidos (pesquisa, lavra, beneficiamento, desativação); e

- redução dos impactos do uso - racionalização do consumo (reciclagem e reuso) das substâncias minerais e dos insumos e matérias-primas empregados na produção.

Impacto ambiental pode ser definido como "alteração da qualidade ambiental que resulta da modificação de processos naturais ou sociais provocada por ação humana" (SÁNCHEZ, 2006, p. 32). Os impactos ambientais da mineração são divididos de acordo com o meio afetado, físico, biótico e antrópico, sendo que a maior parte dos efeitos da mineração atinge primeiro o meio físico, e os outros em decorrência (DIAS, 2001, p. 88).

De acordo com Sánchez (2006, p. 203) os principais impactos ambientais de um empreendimento de mineração são, de acordo com o meio:

$>$ meio físico - alteração da qualidade das águas superficiais e subterrâneas, do regime de escoamento das águas subterrâneas, da qualidade do ar e do solo, e das condições climáticas locais;

meio biótico - alteração dos habitats terrestres e aquáticos, redução da produção primária, diminuição da disponibilidade de nutrientes e da produtividade dos ecossistemas, deslocamento da fauna e perda de espécimes, criação de novos ambientes e proliferação de vetores; e

$>$ meio antrópico - impacto visual, desconforto ambiental, riscos à saúde humana, substituição de atividades econômicas, incremento da atividade comercial, aumento local de preços, aumento da população, sobrecarga da infraestrutura de serviços, expansão da infraestrutura local e regional, perda de patrimônio cultural e de referências espaciais à memória e à cultura popular, redução da diversidade cultural, alteração dos modos de vida tradicionais e das relações socioculturais e limitação das opções de uso do solo.

Como expôs Salum (2003), o Tratamento de Minérios apresenta como grande desafio para os próximos anos a sua contribuição para o que veio a ser denominado mineração sustentável. Este desafio traz em si a necessidade de avanços e inovações para a área, além de uso mais qualificado e abrangente daquilo que já se dispõe em termos de tecnologia. Ao se aliar mineração sustentável e Tratamento de 
Minérios, há múltiplos aspectos a serem considerados. São exemplos de ações do Tratamento de Minérios que podem resultar na sua contribuição para a mineração sustentável:

- recuperação de finos de minérios de baixo teor;

- recuperação de rejeitos da mineração;

- otimização do consumo de reagentes de flotação e de separação sólido/líquido;

- busca por reagentes menos agressivos ambientalmente para as operações de flotação e de separação sólido-líquido; e

- otimização de uso de energia e água no tratamento de minérios.

Felizmente, o compromisso de minimizar 0 impacto das atividades econômicas no meio ambiente foi incorporado, nas últimas décadas, aos planos de investimentos e ao crescimento da maioria das empresas de mineração.

\subsection{ALUMÍNIO}

O alumínio ( $\mathrm{Al}$ ) é o terceiro elemento químico mais abundante na crosta terrestre, correspondente a 7,5\%, atrás apenas do oxigênio (O) com 49,5\% e do silício (Si) com $25,7 \%$. Sua distribuição na crosta se dá como principal constituinte de diferentes rochas e solos. É um metal de baixo peso específico, dúctil, maleável, resistente à corrosão e com alta condutibilidade térmica e elétrica. É empregado nas mais diversas atividades econômicas como transporte (aeroespacial, marinho, ferroviário e automotivo), embalagem (produtos farmacêuticos, de limpeza, higiene, bebidas e alimentícios), construção (esquadrias, telhas, revestimentos, peças de acabamento) e outras (indústria elétrica, agricultura, mineração).

Segundo a Associação Brasileira do Alumínio (ABAL), no ano 6.000 a.C. os persas já produziam vasos e recipientes de argila que continha óxido de alumínio (alumina). Povos antigos do Egito e da Babilônia (3.000 a.C.) também utilizavam argilas com alumina para fabricação de cosméticos, medicamentos e corantes de tecidos. O registro mais antigo do metal alumínio (BÁRDOSSY; ALEVA, 1990) consta de 300 a.C. em um ornamento de um cinto pertencente ao general chinês Chou Chou. Depois deste fato, há registros de que o imperador Tibério (14-37 d.C.) 
foi presenteado com um prato de jantar feito de alumínio, mas a pessoa que descobriu o processo para obtenção do alumínio foi rapidamente eliminada para evitar uma queda no preço do ouro e da prata, que eram de posse do império.

Em 1821, o geólogo Pierre Berthier provou a existência de hidróxido de alumínio em um material avermelhado encontrado em Les Baux, na França Meridional, sendo esta a origem do nome bauxita para a rocha composta por hidróxidos de alumínio, silicatos, óxidos de ferro e titânio. Dane Christian Oersted conseguiu, em 1825, isolar o alumínio pela redução de cloreto de alumínio. No ano de 1869, Henri Sainte-Claire Deville estava apto a produzir $2 \mathrm{t}$ de alumínio por ano, financiado pelo imperador Napoleão III, para fabricar aparatos leves para os soldados (BÁRDOSSY; ALEVA, 1990).

A história moderna do alumínio tem início em 1886, quando o norteamericano Charles Martin Hall e o francês Paul Louis Toussaint Héroult desenvolveram, separadamente, o processo de obtenção de alumínio por meio da redução eletrolítica da alumina dissolvida em banho fundido de criolita. O processo Hall-Héroult é único comercialmente utilizado para redução da alumina. Em 1888, a invenção de Karl Josef Bayer de um processo econômico para obter um óxido de alumínio muito puro a partir da bauxita completou a base científica sobre a qual está baseada a indústria do alumínio - transformação de bauxita em alumina pelo processo Bayer e redução da alumina a alumínio pelo processo Hall-Héroult (CUNDIFF, 1985).

\subsubsection{Etapas da obtenção do alumínio}

A produção do alumínio se dá em quatro etapas (CHAVES, 2006):

1. lavra e beneficiamento da bauxita (único minério de alumínio economicamente viável);

2. obtenção de alumina $\left(\mathrm{Al}_{2} \mathrm{O}_{3}\right)$ de alta pureza através do processo Bayer;

3. redução eletrotérmica da alumina a alumínio metálico pelo processo Hall-Héroult; e

4. transformação mecânica do alumínio em chapas, barras, perfis, fios, entre outros. 
A lavra é a extração do minério na jazida, que se dá com a remoção de estéril e sua disposição em depósitos. O beneficiamento é a adequação do minério bruto às especificações de granulometria, teor mínimo de alumina e teor máximo de contaminantes, gera frações que vão para a barragem de contenção de rejeitos. A bauxita beneficiada segue então à fábrica de alumina (usina hidrometalúrgica), onde ocorre a reação da bauxita com soda cáustica em solução, sob pressão e temperatura adequadas, conforme a equação 1 simplificada:

$$
\mathrm{Al}_{2} \mathrm{O}_{3} \cdot 3 \mathrm{H}_{2} \mathrm{O}+2 \mathrm{NAOH} \rightarrow 2 \mathrm{NaAlO}_{2}+4 \mathrm{H}_{2} \mathrm{O}
$$

O aluminato de sódio permanece em solução e as impurezas insolúveis presentes no minério precipitam, resultando em sólidos muito finos, que são separados por classificação e filtragem; gerando a chamada lama vermelha, um resíduo problemático composto por óxidos de ferro, titânio, sílica, silicatos de alumínio e sódio hidratados, demais minerais de ganga e a soda cáustica arrastada. A lama vermelha é um dos problemas ambientais mais sérios na indústria do alumínio, ao lado do grande consumo de energia.

A regeneração da alumina ocorre pela cristalização e nucleação com cristais de alumina (semeadura), o que resulta na precipitação da alumina, equação 2 :

$$
2 \mathrm{NaAlO}_{2}+4 \mathrm{H}_{2} \mathrm{O} \rightarrow \mathrm{Al}_{2} \mathrm{O}_{3} \cdot 3 \mathrm{H}_{2} \mathrm{O} \downarrow+2 \mathrm{NaOH}
$$

A alumina hidratada é filtrada e calcinada em fornos de leito fluidizado para eliminar a água de hidratação:

$$
\mathrm{Al}_{2} \mathrm{O}_{3} \cdot 3 \mathrm{H}_{2} \mathrm{O} \stackrel{\Delta}{\longrightarrow} \mathrm{Al}_{2} \mathrm{O}_{3}+3 \mathrm{H}_{2} \mathrm{O} \uparrow
$$

O processo descrito acima é o processo Bayer e a etapa seguinte, para obtenção do alumínio metálico, ocorre em usina metalúrgica chamada "smelter" através do processo Hall-Héroult. No "smelter", a redução do óxido de alumínio a alumínio metálico é feita em células eletrolíticas, a alta temperatura (acima de $\left.930^{\circ} \mathrm{C}\right)$, utilizando o coque como redutor e a criolita $\left((\mathrm{NaF}) 3 \mathrm{AlF}_{3}\right)$ como fundente, segundo a reação 4 :

$$
\mathrm{Al}_{2} \mathrm{O}_{3}+3 \mathrm{C} \rightarrow 2 \mathrm{Al}+3 \mathrm{CO}
$$

que é resultado da redução do $\mathrm{Al}^{3+}$ que ocorre no catodo (5) e da oxidação do carbono no anodo (6):

$$
\mathrm{Al}^{3+}+3 \mathrm{e}^{-} \rightarrow \mathrm{Al}
$$




$$
\mathrm{O}^{2-}+\mathrm{C} \rightarrow \mathrm{CO}+2 \mathrm{e}^{-}
$$

A criolita é sintetizada a partir da fluorita $\left(\mathrm{CaF}_{2}\right)$ e a reação eletrotérmica gera vapores que reagem com 0 ar e formam ácido fluorídrico (HF), que reage com alumínio metálico e com o carbono dos eletrodos, resultando em tetrafluoreto de carbono. Os eletrodos são de grafite ou de pasta Soderberg (antracito, grafite e coque de petróleo, ligados com piche). A sala de cubas é um ambiente poluído e altamente controlado, visto que parte do piche volatiliza, pequenas quantidades de enxofre são emitidas e componentes orgânicos como benzo( $\alpha)$ antraceno, benzofluoranteno, entre outros, também são poluentes. A figura 2 ilustra todo 0 processo de obtenção do alumínio com um balanço de massas típico.

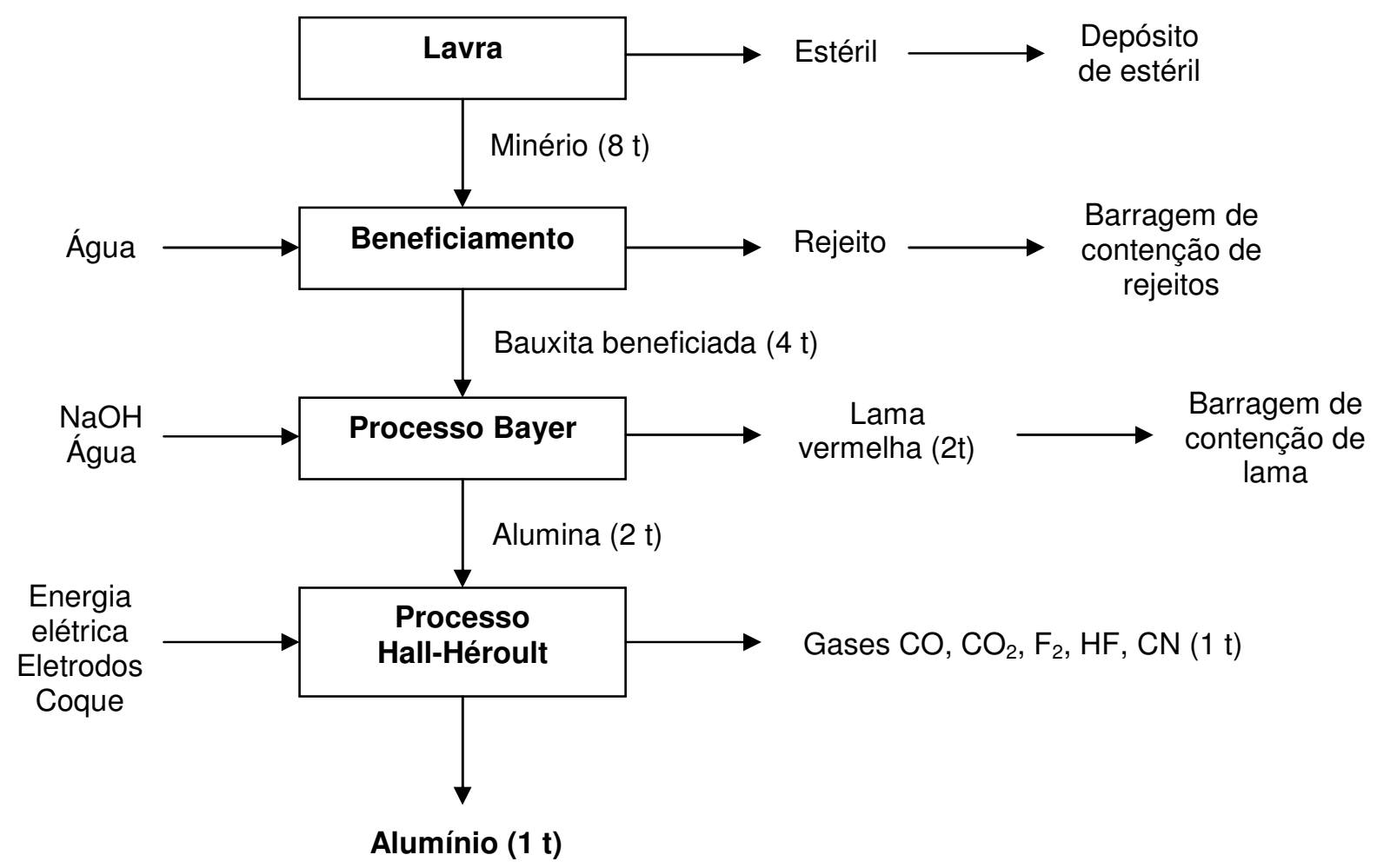

Figura 2 - Etapas de fabricação do alumínio

\subsubsection{Produção}

Segundo dados do Mineral Commodity Summaries (2008), a produção mundial estimada de alumínio primário no ano de 2007 foi de 37,78 milhões de toneladas, destacando-se a China como maior produtor, com 12 milhões de 
toneladas. O Brasil ficou em sexto lugar, com 1,7 milhões de toneladas. A tabela 1 mostra a produção de alumínio primário por países e a total mundial, de 2003 a 2007 e o gráfico 1 a evolução da produção nos principais países produtores. De 2003 a 2007, a China aumentou sua participação na produção mundial de alumínio de $20 \%$ para $32 \%$, enquanto os outros países diminuíram um pouco ou permaneceram estáveis. Com relação à produção, a China aumentou de 5,45 milhões de toneladas em 2003 para 12 milhões em 2007, o que representa um aumento de $120 \%$. No mesmo período, o Brasil aumentou sua produção em $23 \%$, enquanto a Rússia aumentou $21 \%$, o Canadá $11 \%$, a Austrália $2 \%$ e os Estados Unidos diminuíram a produção em $3,8 \%$.

Tabela 1 - Produção mundial de alumínio primário (mil t)

\begin{tabular}{c|c|c|c|c|c}
\hline \multirow{2}{*}{ Países } & \multicolumn{5}{|c}{ Ano } \\
\cline { 2 - 6 } & $\mathbf{2 0 0 3}$ & $\mathbf{2 0 0 4}$ & $\mathbf{2 0 0 5}$ & $\mathbf{2 0 0 6}$ & $\mathbf{2 0 0 7} \mathrm{e}$ \\
\hline China & 5.450 & 6.670 & 7.800 & 9.350 & 12.000 \\
Rússia & 3.480 & 3.590 & 3.650 & 3.720 & 4.200 \\
Canadá & 2.790 & 2.590 & 2.890 & 3.050 & 3.100 \\
Estados Unidos & 2.703 & 2.516 & 2.481 & 2.284 & 2.600 \\
Austrália & 1.860 & 1.900 & 1.900 & 1.930 & 1.900 \\
Brasil & 1.380 & 1.460 & 1.500 & 1.498 & 1.700 \\
Índia & & & 898 & 1.100 & 1.400 \\
Noruega & 1.150 & 1.320 & 1.370 & 1.330 & 1.100 \\
África do Sul & 738 & 863 & 851 & 895 & 900 \\
Emirados Àrabes Unidos & & & 750 & 730 & 900 \\
Bahrein & & & 751 & 872 & 870 \\
Venezuela & 601 & 624 & 610 & 610 & 630 \\
Moçambique & 405 & 547 & 555 & 564 & 560 \\
Alemanha & & & 668 & 537 & 520 \\
Tadjiquistão & & & & 414 & 500 \\
Islândia & & & & 320 & 400 \\
Outros & 7.160 & 7.710 & 5.190 & 4.510 & 4.500 \\
\hline Total & $\mathbf{2 7 . 7 1 7}$ & $\mathbf{2 9 . 7 9 0}$ & $\mathbf{3 1 . 8 6 4}$ & $\mathbf{3 3 . 7 1 4}$ & $\mathbf{3 7 . 7 8 0}$ \\
\hline
\end{tabular}

Fonte: U.S. Geological Survey, Mineral Commodity Summaries, 2008. e: estimado. 


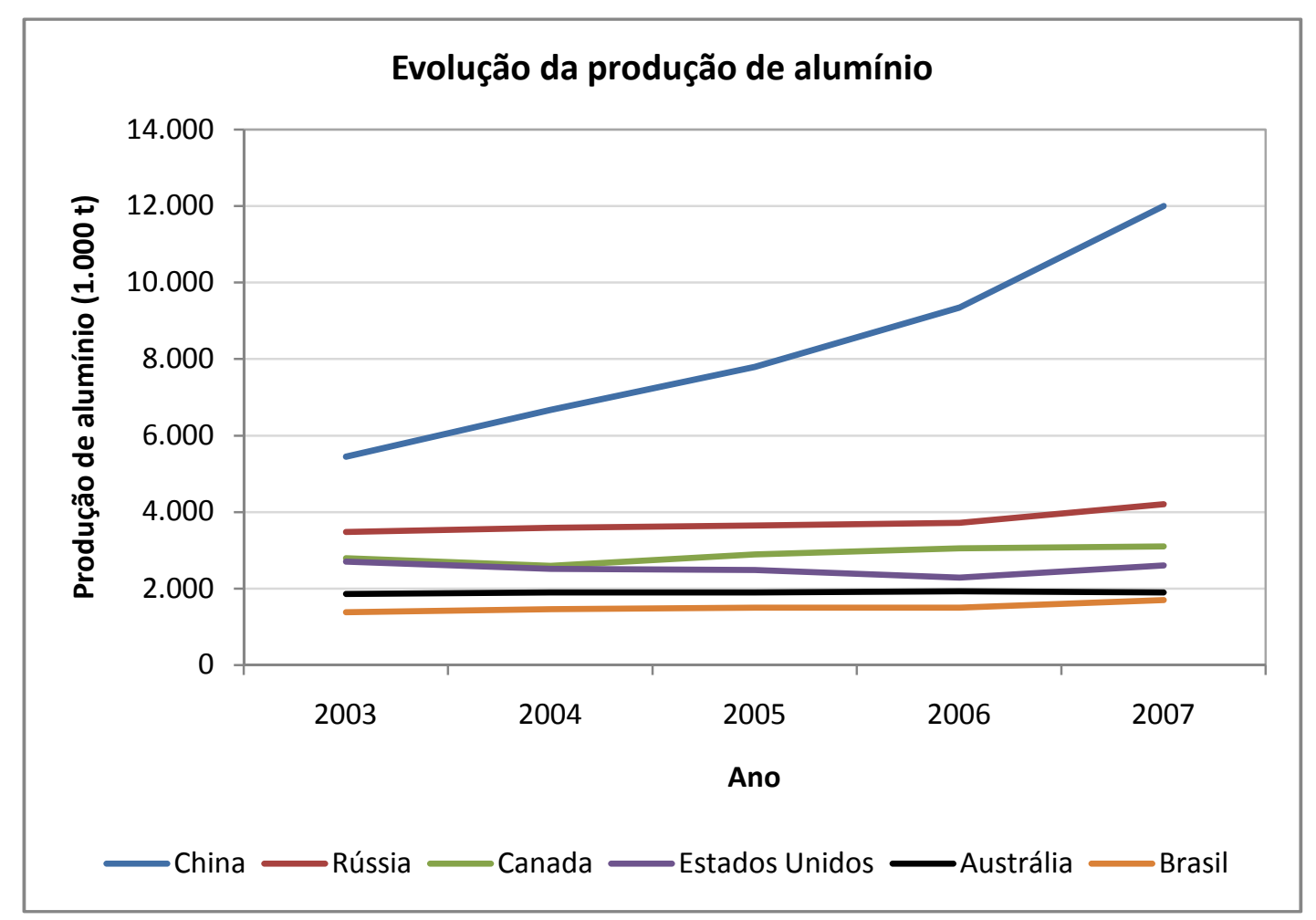

Gráfico 1 - Evolução da produção de alumínio primário

\subsubsection{Evolução do preço}

De 2003 a meados de 2008, o preço do alumínio primário apresentou uma tendência de crescimento, com algumas pequenas quedas, atingindo um pico em maio de 2006, com um preço de, aproximadamente, US $\$ 3,300.00 / t$ (gráfico 2). Após a subida recorde, o preço caiu e não ultrapassou os US\$3,000.00/t, até o ano de 2008. No início de 2008 o preço subiu a, aproximadamente, US\$ 3,200.00/t, caindo um pouco nos meses seguintes e atingindo outro pico próximo a US $\$ 3,300.00 / \mathrm{t}$ em agosto de 2008. Depois deste pico, o preço caiu quase $43 \%$, chegando a US\$ 1,900.00/t em meados de novembro. Esta queda deve-se ao aumento da produção, que superou a expansão da procura e, também, à crise de crédito nos Estados Unidos, que desacelerou a economia mundial, conseqüentemente, a demanda e fez com que os fundos que aplicavam em commodities passassem a outras aplicações financeiras, mais seguras. 


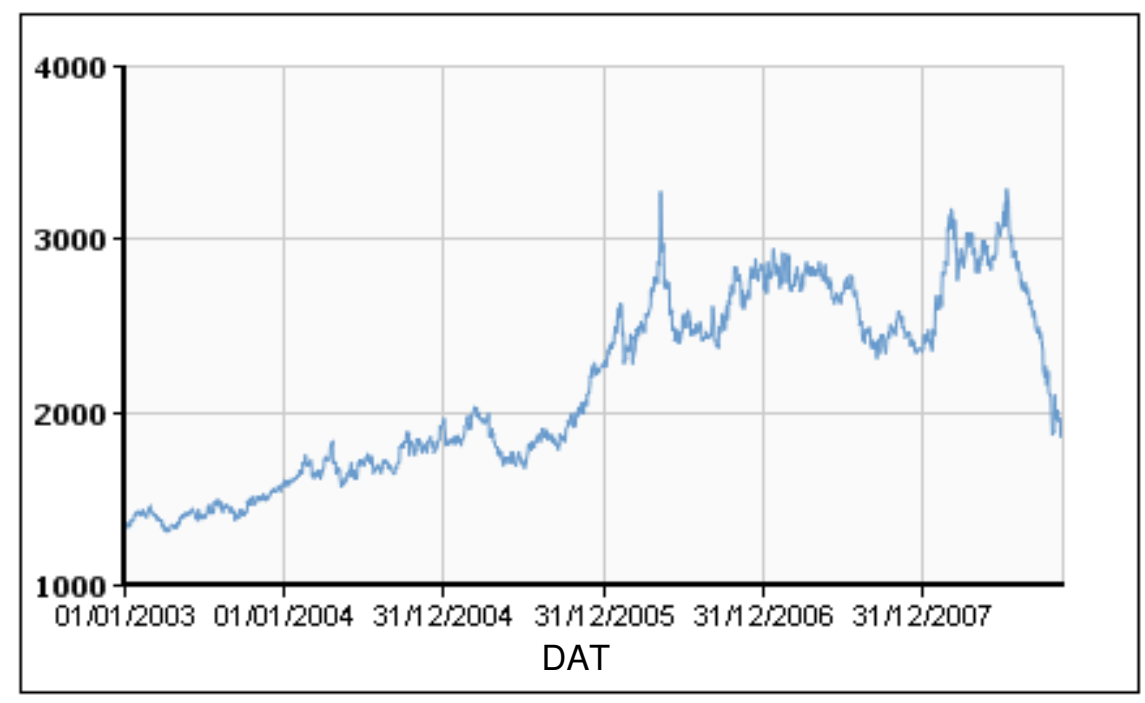

Fonte: LME (London Metal Exchange).

Gráfico 2 - Evolução do preço de alumínio primário (preço em US\$/t)

\subsection{BAUXITA}

O nome bauxita foi dado por Dufrenoy em 1837 (BÁRDOSSY; ALEVA, 1990), em referência ao local onde foi descoberta a bauxita por Berthier, uma cidade medieval chamada Les Beaux (posteriormente Les Baux), onde foi confirmada a existência de um depósito cárstico de bauxita.

É uma rocha cuja coloração pode ser branca ou avermelhada, dependendo da quantidade de óxidos de ferro presente, sendo que a vermelha chega a ter $25 \%$ destes. A rocha bauxita é composta de uma mistura impura dos seguintes minerais de alumínio, gibsita $\mathrm{Al}(\mathrm{OH})_{3}$, bohemita $\mathrm{AlO}(\mathrm{OH})$ e diásporo $\mathrm{HAlO}_{2}$. Estes minerais são oxi-hidróxidos de alumínio e suas proporções na rocha variam entre os depósitos e com a quantidade de impurezas. Estas podem ser sílica, alumino silicatos, óxidos de ferro e dióxido de titânio. Bauxitas economicamente aproveitáveis possuem entre 50 e $55 \%$ de alumina $\left(\mathrm{Al}_{2} \mathrm{O}_{3}\right)$ e o teor mínimo para que seja aproveitável é em torno de 30\% (SAMPAIO; ANDRADE; DUTRA, 2005).

Sua origem é supergênica, comumente sob condições climáticas tropicais e subtropicais. Os depósitos tropicais são lateríticos, oxidados, consistindo de hidróxidos de alumínio e óxidos de ferro, principalmente (HURLBUT, 1959). 


\subsubsection{Depósitos de bauxita}

Há três tipos de depósitos de bauxita no mundo (BÁRDOSSY; ALEVA, 1990): lateríticos, cársticos e tipo Tikhvin. Eles estão distribuídos conforme mostra a figura 3.

Os principais depósitos lateríticos são encontrados no Brasil, Guiana, Índia, África e Austrália. Sua formação é resultante de processos de laterização, isto é, as rochas são formadas pelo intemperismo tropical e paleo-tropical a partir de rochas aluminossilicáticas. As províncias de depósitos lateríticos do mundo aparecem na figura 4. 


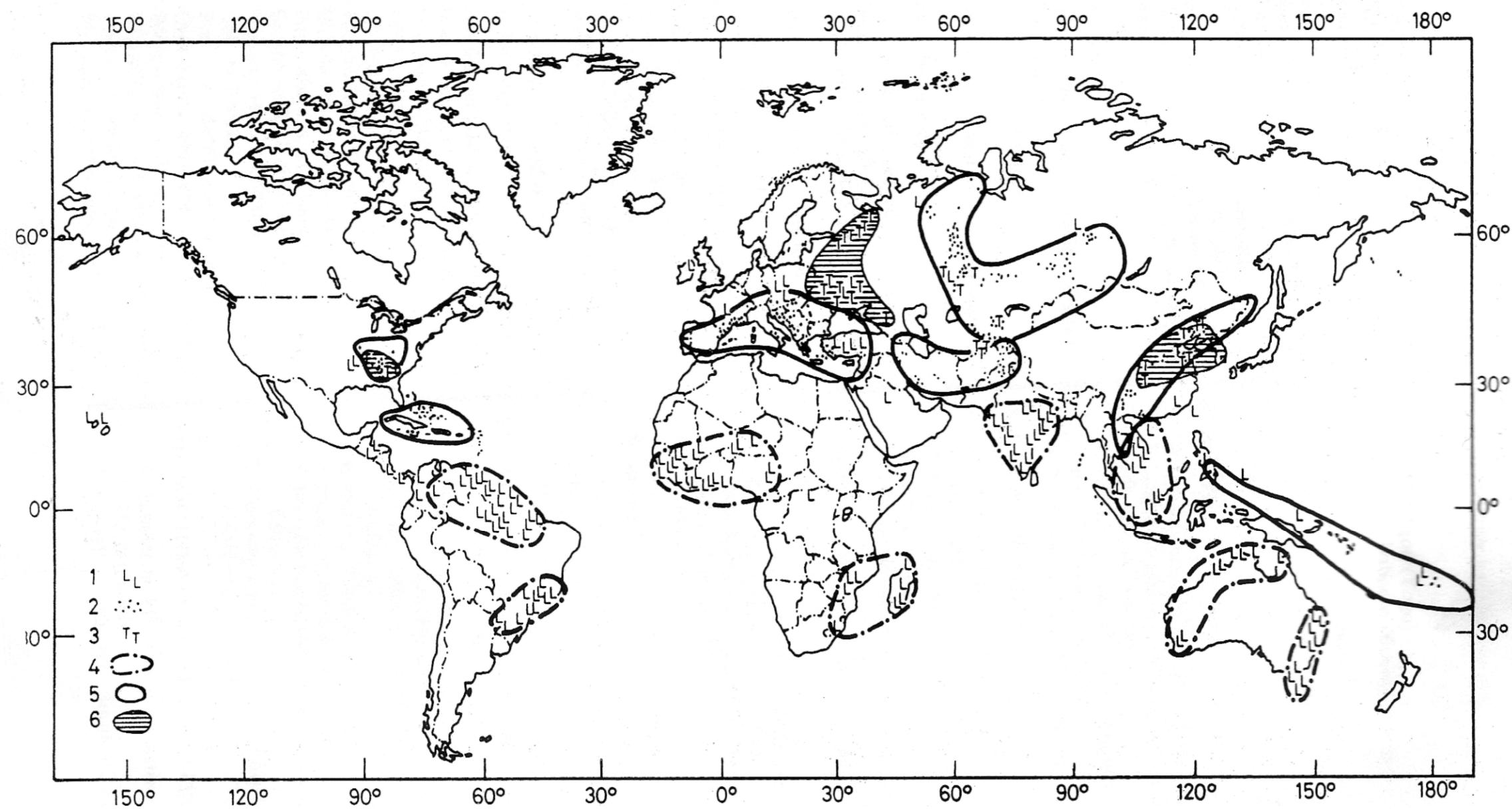

1: bauxitas lateríticas; 2: bauxitas cársticas; 3: bauxitas tipo Tikhvin-type; 4: províncias lateríticas; 5: províncias cársticas; 6: províncias tipo Tikhvintype (BÁRDOSSY;ALEVA,1990). 


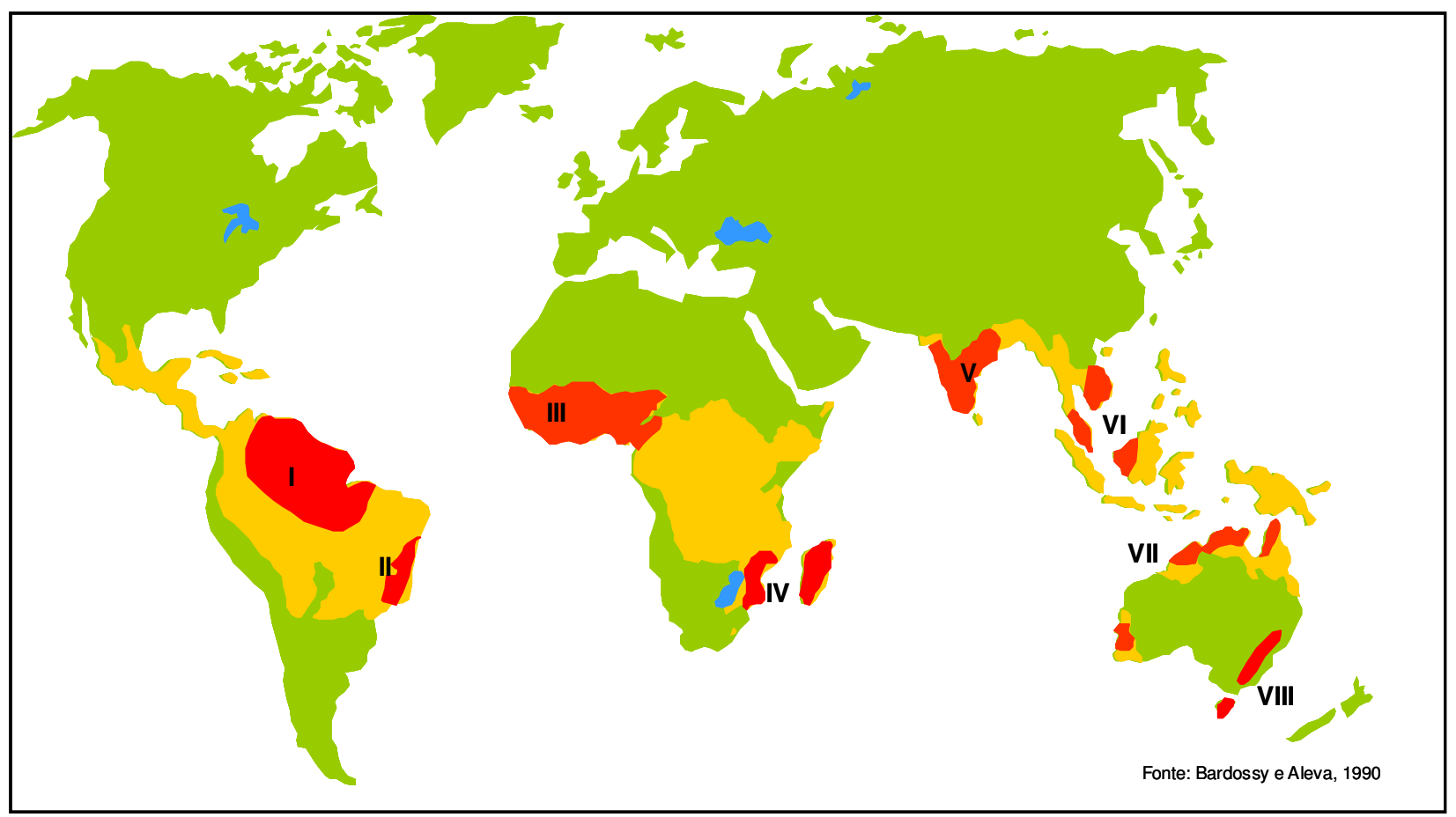

I - Província Plataforma da América do Sul

II - Província Sudeste Brasil

III - Província Oeste Africano

IV - Província Sudeste Africano

$\mathrm{V}$ - Província Indiana

VI - Província Sudeste Asiático

VII - Província Oeste e Norte Australiana

VIII - Província Sudeste Australiano

Figura 4 - Províncias de depósitos lateríticos

\subsubsection{Produção de bauxita}

Há muitas reservas de bauxita no mundo, principalmente nas regiões de clima tropical e subtropical. O total de reservas, considerando o ano de 2007, é de 32 bilhões de toneladas (MINERAL COMMODITY SUMMARIES, 2008) e divide-se, principalmente, entre Guiné $(26,9 \%)$, Austrália $(24,1 \%)$, Brasil $(8,4 \%)$, Jamaica $(7,8 \%)$, China (7,2\%), Índia (4,4\%), Guiana (2,8\%), Suriname $(1,9 \%)$ e Venezuela $(1,1 \%)$. É relativamente pequeno o número de países que produzem bauxita e, destes, são poucos os que beneficiam o minério. Em 2007, a produção mundial de bauxita foi de 193,6 Mt, das quais $83,1 \%$ foram produzidas por seis países: Austrália $(33,1 \%)$, China (16,5\%), Brasil $(12,4 \%)$, Guiné $(7,2 \%)$, Jamaica $(7,2 \%)$ e Índia $(6,7 \%)$. A tabela 2 mostra a produção e reservas mundiais de bauxita. 
Tabela 2 - Produção e reservas de bauxita no mundo

\begin{tabular}{|c|c|c|c|c|c|c|}
\hline \multirow[b]{2}{*}{ País } & \multicolumn{4}{|c|}{ Produção de bauxita } & \multicolumn{2}{|c|}{ Reservas } \\
\hline & $\begin{array}{l}2006 \\
\left(10^{3} t\right)\end{array}$ & (\%) & $\begin{array}{c}2007 e \\
\left(10^{3} t\right)\end{array}$ & (\%) & $\begin{array}{l}2007 \\
\left(10^{3} t\right)\end{array}$ & (\%) \\
\hline Brasil & 22.836 & $12,7 \%$ & 24.754 & $12,7 \%$ & 2.500 .000 & $7,7 \%$ \\
\hline Austrália & 62.300 & $34,7 \%$ & 64.000 & $32.9 \%$ & 7.900 .000 & $24,4 \%$ \\
\hline Cazaquistão & 4.800 & $2,7 \%$ & 4.900 & $2,5 \%$ & 450.000 & $1,4 \%$ \\
\hline China & 21.000 & $11,7 \%$ & 32.000 & $16,5 \%$ & 2.300 .000 & $7,1 \%$ \\
\hline Estados Unidos & nd & nd & nd & nd & 40.000 & $0,1 \%$ \\
\hline Grécia & 2.450 & $1,4 \%$ & 2.400 & $1,2 \%$ & 650.000 & $2,0 \%$ \\
\hline Guiné & 14.500 & $8,1 \%$ & 14.000 & $7,2 \%$ & 8.600 .000 & $26,5 \%$ \\
\hline Guiana & 1.400 & $0,8 \%$ & 2.000 & $1,0 \%$ & 900.000 & $2,8 \%$ \\
\hline Índia & 12.700 & $7,1 \%$ & 13.000 & $6,7 \%$ & 1.400 .000 & $4,3 \%$ \\
\hline Jamaica & 14.900 & $8,3 \%$ & 14.000 & $7,2 \%$ & 2.500 .000 & $7,7 \%$ \\
\hline Rússia & 6.600 & $3,7 \%$ & 6.000 & $3,1 \%$ & 250.000 & $0,8 \%$ \\
\hline Suriname & 4.920 & $2,7 \%$ & 5.000 & $2,6 \%$ & 600.000 & $1,8 \%$ \\
\hline Venezuela & 5.500 & $3,1 \%$ & 5.500 & $2,8 \%$ & 350.000 & $1,1 \%$ \\
\hline Outros & 5.460 & $3,0 \%$ & 6.800 & $3,5 \%$ & 4.000 .000 & $12,3 \%$ \\
\hline TOTAL & 179.366 & $100,0 \%$ & 194.354 & $100,0 \%$ & 32.440 .000 & $100,0 \%$ \\
\hline
\end{tabular}

Fonte: U.S. Geological Survey, Mineral Commodity Summaries, 2008; DNPM, Sumário Mineral 2008. Nota: (e) dados preliminares, exceto Brasil; (nd) não-disponível.

A Austrália é o maior produtor de bauxita do mundo com 64,0 Mt em 2007. Há cinco minas de bauxita em operação na Austrália: Huntly, Weipa, Gove, Willowdale e Mt Saddleback. Até 2005, a maior mina era Huntly, que produziu 18,0 Mt, enquanto Weipa, a segunda maior, produziu 11,9 Mt no mesmo ano. Em 2007, após um projeto de expansão, a mina Weipa atingiu uma capacidade de produção anual de 18,2 Mt (COMMODITY REPORTS, 2008).

A China foi o segundo maior produtor com 32,0 Mt de bauxita, que são de natureza diaspórica, com alto teor de sílica e óxidos de titânio. O suprimento de bauxita na China é complicado de mapear, pois são, aproximadamente, 300 produtores de bauxita e o minério raramente é de um local apenas.

O Brasil, com 24,7 Mt, foi o terceiro maior produtor, sendo que a Mineração Rio do Norte (MRN) foi a maior produtora, com suas minas em Porto Trombetas (PA), atingindo 18 Mt em 2007 (MÁRTIRES, 2008), o que representa 73\% da produção brasileira. A Companhia Brasileira de Alumínio (CBA) vem em segundo lugar com uma produção de 2,8 Mt em 2007, correspondente a 11,5\% da produção 
nacional, operando as minas de Itamarati de Minas, Descoberto e Poços de Caldas (MG), sendo que em junho de 2008 entrou em operação a nova unidade de produção em Miraí (MG) com capacidade de produzir até $4 \mathrm{Mt} / \mathrm{ano}$ em plena capacidade. Em terceiro lugar vem a Vale, com produção de $1,85 \mathrm{Mt}(7,5 \%$ da produção do país), com a entrada em operação da mina em Paragominas (PA). Seguindo a Vale, aparece a Alcoa com 4,9\% da produção, equivalentes a 1,21 Mt, com suas minas em Poços de Caldas (MG), sendo que em 2009 está previsto o início da operação de uma nova mina em Juruti (PA), com capacidade inicial de 2,6 Mt/ano. Em quinto lugar está a Novelis com produção de 0,47 Mt em 2007, 1,9\% da produção, com suas minas em Caeté e Mariana (MG).

A bauxita grau refratária representou apenas $1,2 \%$ do total da bauxita produzida no país, tendo como principal produtor a Mineração Curimbaba instalada em Minas Gerais (MÁRTIRES, 2008). A produção de alumina apresentou um pequeno acréscimo de 1,5\% em 2007, com produção de 6,89 Mt distribuída entre Alunorte (52\%), Alcoa (20\%), CBA (13\%), Billiton (10\%) e Novelis $(5 \%)$. O principal produto importado foi a bauxita calcinada, totalizando 416 mil toneladas.

\subsubsection{Beneficiamento de bauxita}

A bauxita lavrada no mundo atualmente não requer um beneficiamento complexo como outros minérios de metais base, visto que os teores dos minérios são naturalmente aceitáveis ou podem ser enriquecidos com processos simples e não muito caros para remoção da argila. Na maioria dos minérios os argilo-minerais são removidos por uma combinação de lavagem, peneiramento a úmido e ciclonagem.

Na mina de Gove, terceira maior da Austrália, a bauxita é lavrada e britada na própria mina, antes de ser transportada para a refinaria de alumina por um transportador de correia de 18,7 km. A CBG (Cie des Bauxites de Guinée's), maior produtora de bauxita na Guiné, utiliza para o tratamento do minério a britagem (abaixo de $100 \mathrm{~mm}$ ) e a secagem até umidade de 6,7\% (partindo de 12,5\%) antes de embarcá-lo nos navios. 
No Brasil, em Porto Trombetas (PA), a MRN possui uma planta de beneficiamento que faz a adequação da granulometria do produto e a redução da lama contida, através de britagem, escrubagem, classificação por tamanhos e filtragem. A CBA, em Itamarati de Minas, utiliza a escrubagem, peneiramento, separação densitária e magnética.

Não foram encontrados relatos de nenhuma empresa que utilize a flotação industrialmente para concentração da bauxita.

Apenas alguns trabalhos experimentais foram encontrados (MASSOLA et al., 2009), como o de Bittencourt (1989) e Bittencourt; Lin e Miller (1990), que tentou a flotação direta de um minério brasileiro composto por gibsita (50\%), caulinita (15\%) e quartzo (35\%), em duas etapas: a primeira foi a flotação de gibsita/caulinita do quartzo, em pH 2, utilizando alquil sulfato como coletor; a segunda foi a flotação da caulinita da gibsita, com aminas como coletor, em pH 8.

Alguns trabalhos chineses sobre a viabilidade de aumentar a relação $\mathrm{Al}_{2} \mathrm{O}_{3} / \mathrm{SiO}_{2}$ de uma bauxita diaspórica pela remoção do quartzo através da flotação também foram encontrados (LIU et al., 2007; WANG et al., 2004; XU et al., 2004).

Por fim, Massola (2008), dando continuidade aos trabalhos descritos nesta dissertação, realizou ensaios em bancada e em usina piloto para concentrar gibsita através da flotação reversa da sílica. Foi demonstrada a aplicabilidade deste processo à bauxita de Miraí, MG, da CBA, com recuperações de $28,8 \%$ em massa e $81,2 \%$ metalúrgica, com teor de $54 \%$ de alumina aproveitável, após a separação magnética.

\subsubsection{Bauxita brasileira}

Os depósitos de bauxita do Brasil são de origem laterítica e, segundo Carvalho et al. (1997) constituídos essencialmente por gibsita e formados pela ação intensa do clima tropical sobre diferentes tipos de rocha. As condições climáticas e geomorfológicas, juntas com o tempo, são os fatores mais importantes na formação destes depósitos.

O minério objeto deste estudo é a bauxita de Itamarati de Minas, região de Cataguases, MG. Este depósito está localizado no sudeste de Minas Gerais e forma 
um longo cinturão que se estende de São João do Nepomuceno até Manhumirim, figura 5. Possui mais de 100 milhões de toneladas de bauxita, a maior reserva de alumínio do Brasil. Ocorre em topos de morros (700 a $900 \mathrm{~m}$ ) em uma topografia conhecida por "meia-laranja". Este minério é composto, segundo Carvalho et al. (1997), principalmente, por:

- sílica $\left(\mathrm{SiO}_{2}\right)$, variando de 2 a $10 \%$ para derivados de rochas básicas e até $24 \%$ para derivados de rochas ácidas. Aparece na forma de quartzo ou combinado com alumina (caulinita $-\mathrm{Al}_{2} \mathrm{O}_{3} \cdot 2 \mathrm{SiO}_{2} \cdot 2 \mathrm{H}_{2} \mathrm{O}$ ). No processo Bayer, a sílica na forma de quartzo é inócua, mas os argilominerais, entre eles a caulinita, são nocivos, pois consomem a soda cáustica e retiram alumina;

- alumina $\left(\mathrm{Al}_{2} \mathrm{O}_{3}\right)$, torna-se enriquecida na forma de caulinita ou gibsita. Uma parte também é fixada em minerais de ferro. O teor varia entre $40 \%$ (rochas básicas) e 50\%, com um máximo de 60\% (em outros tipos);

- ferro (Fe), o minério anfibolítico tem perto de $30 \%$, enquanto o gnáissico tem entre 15 e $21 \%$; e

- titânio (Ti), incorporado em anfibólios e biotita (3 a $6 \%$ de $\mathrm{TiO}_{2}$ ) em adição aos minerais primários (ilmenita, rutilo). Também ocorre nos minerais secundários de ferro.

Em Itamarati de Minas, as jazidas são de minério gnáissico, cujos principais contaminantes são quartzo $\left(\mathrm{SiO}_{2}\right)$ e argilo-minerais. Em Descoberto, as jazidas são de minério anfibolítico e os principais contaminantes são os óxidos de ferro e titânio $\left(\mathrm{Fe}_{2} \mathrm{O}_{3}\right.$ e $\left.\mathrm{TiO}_{2}\right)$ e argilo-minerais. 


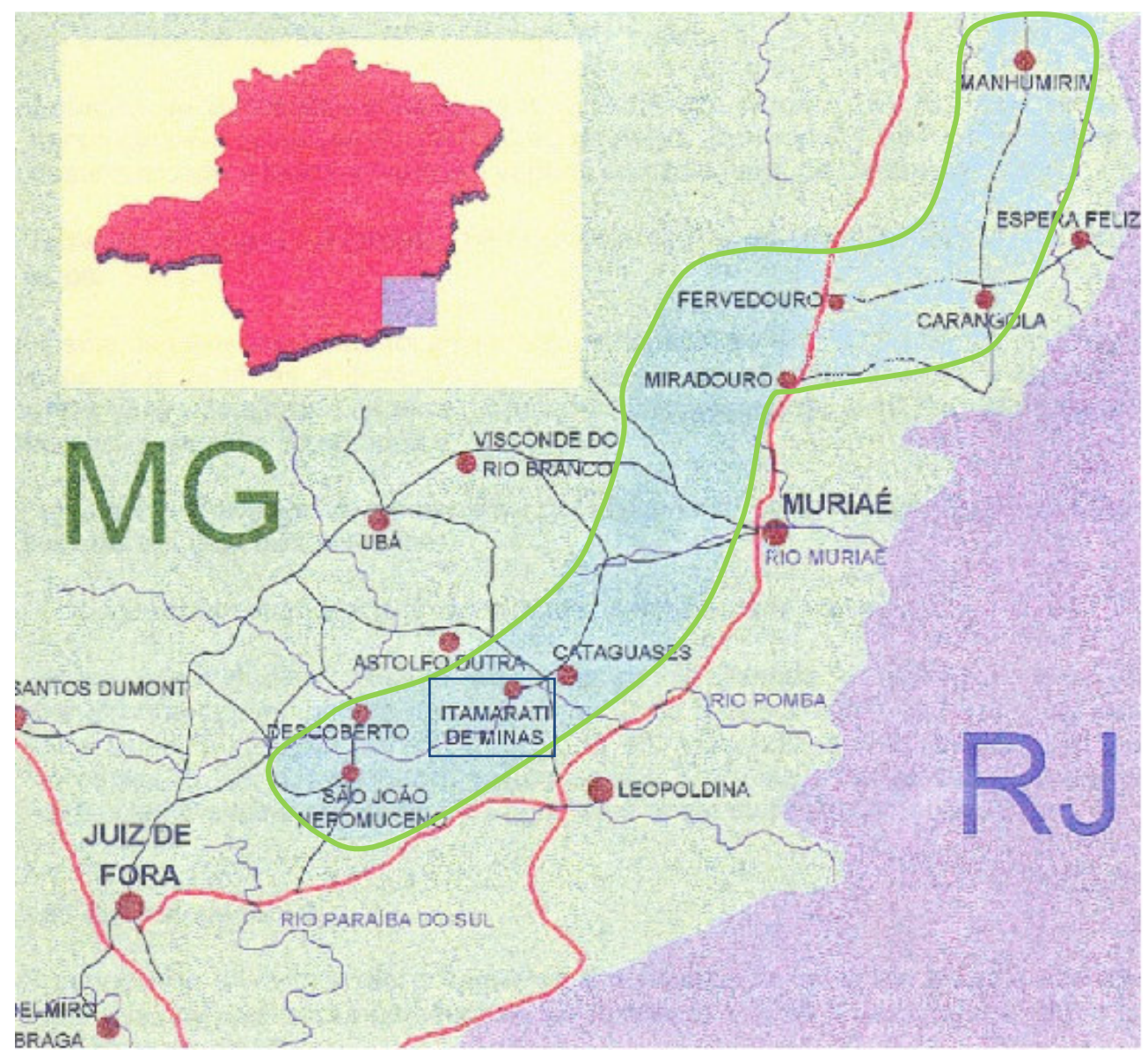

Figura 5 - Localização regional do depósito de bauxita

\subsection{FLOTAÇÃO DE SILICATOS}

Silicatos são os minerais mais comuns e abundantes da crosta terrestre. Mais de $25 \%$ da crosta terrestre consiste de compostos de silício. A unidade fundamental de todos os silicatos é o íon [SiO4] ${ }^{-4}$ que forma um tetraedro. A extensão deste tetraedro em três dimensões forma uma macromolécula conhecida como sílica. Nela, cada átomo de silício é ligado a quatro átomos de oxigênio e cada um deste é ligado a outro de silício (MANSER, 1975).

Segundo Gaudin (1932), flotação é um processo de separação de finos, aplicada na concentração de minérios metálicos, não-metálicos e também na separação de sólidos e gorduras dos líquidos. Antes da flotação é necessário cominuir o minério para a liberação das partículas. A separação por flotação em espuma é feita em água, onde partículas de algumas espécies minerais aderem a 
bolhas de ar que são introduzidas na polpa e flutuam, e outras partículas de outras espécies aderem à água e permanecem no fundo. A segregação de diferentes sólidos é acompanhada pela afinidade seletiva de suas superfícies, adequadamente modificadas por reagentes, pelas bolhas de ar ou pela água. A flotação da sílica, na forma de quartzo, tem sido estudada mais que a flotação de todos os outros silicatos. Isto devido à sua larga ocorrência na forma pura e sua conveniente insolubilidade na água.

Os coletores são substâncias que envolvem as partículas e as tornam capazes de aderirem às bolhas de ar. Como explicam Chaves e Leal Filho (2002), a estrutura molecular dos coletores é caracterizada por uma porção de natureza molecular (covalente) e outra de natureza polar (iônica). A porção polar pode apresentar diversas funções, enquanto a covalente é sempre uma cadeia orgânica, de comprimento variável, podendo ser ramificada ou mesmo cíclica. Em solução, a porção polar é ionizada e a molecular não, tendo esta maior afinidade pela fase gasosa que pela líquida. Havendo no sistema uma interface sólido-gás (bolhas de ar introduzidas na célula de flotação), a molécula de coletor tenderá a se posicionar nesta interface, de modo que a porção não-polar esteja em contato com o gás e a iônica em contato com a água.

Os coletores podem ser aniônicos ou catiônicos, em função da sua carga iônica. Os catiônicos se restringem às aminas, enquanto os aniônicos se subdividem de acordo com a função química correspondente, em: ácidos graxos ou seus sais, xantatos, sulfatos de alcoila ou arila, alcoóis de enxofre, tiouréias, tiocarbamatos e ditiofosfatos.

Segundo Rose e Rose apud Neder e Leal Filho (2006) as aminas graxas podem ser definidas como um composto alifático derivado da amônia $\left(\mathrm{NH}_{3}\right)$, possuindo cadeia carbônica com um número par de átomos de carbono (entre $8 \mathrm{e}$ 22), classificadas como primárias, secundárias ou terciárias, e cujas matérias-primas principais são os óleos ou gorduras. Neder e Leal Filho (2006) consideram a definição perfeita a não ser pelo fato de não incluir os derivados de aminas geradas a partir de alcoóis sintéticos e que possuem cadeia não necessariamente composta por um número par de carbonos. Os termos primária, secundária e terciária são aplicados de acordo com a quantidade de átomos de hidrogênio da amônia que foram substituídos por grupos alquil. O quaternário de amônio é um cátion carregado 
eletricamente de forma permanente. A figura 6 mostra um fluxograma com o resumo das rotas de produção das aminas e seus derivados.

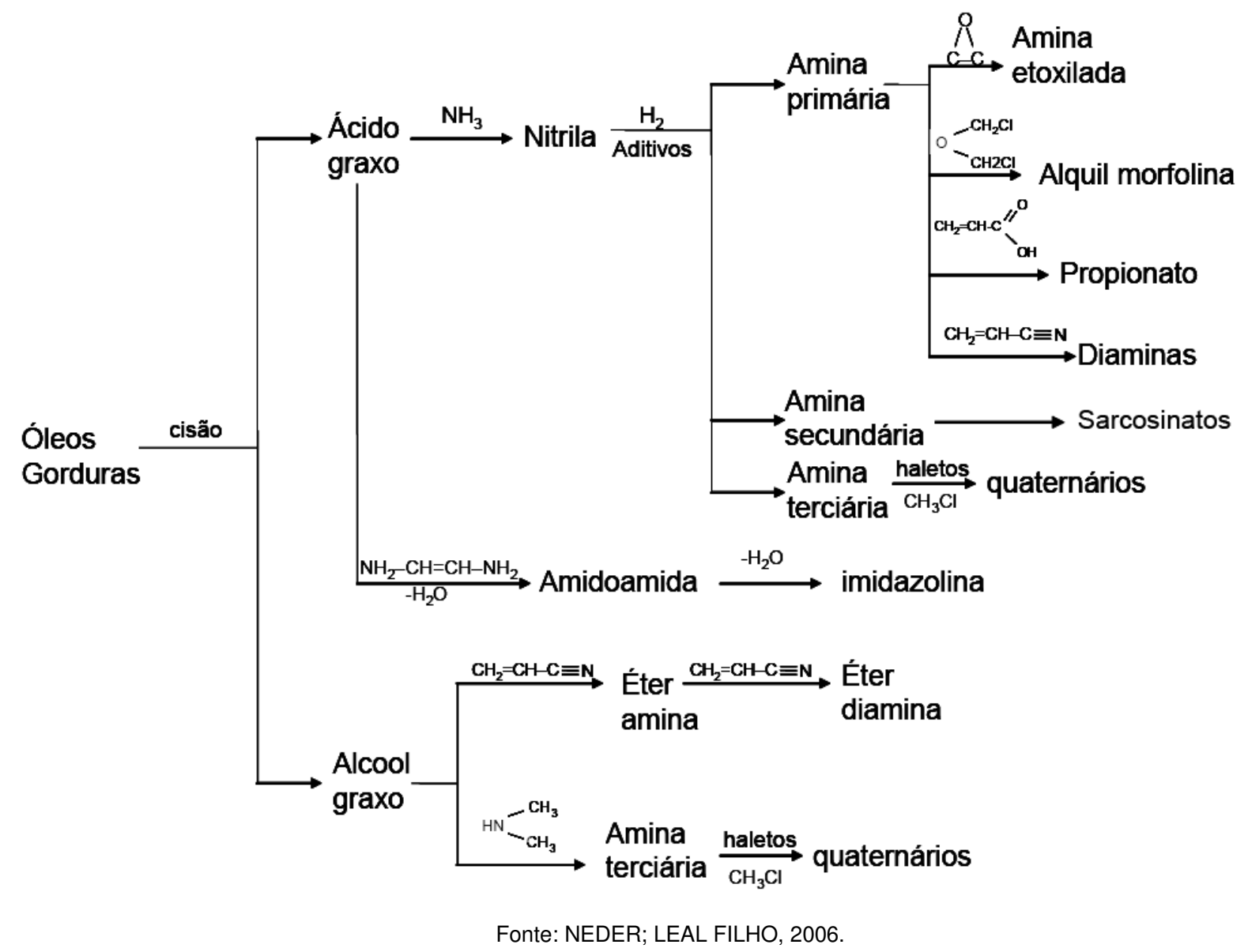

Figura 6 - Rotas de produção das aminas e seus derivados

As aminas e seus acetatos são coletores catiônicos que se ligam à superfície de todos os silicatos. São coletadas eletricamente por um mecanismo de primeira espécie, atração eletrostática entre os cátions de amina e a carga negativa contrária da superfície, sendo adsorvidas e dessorvidas fácil e rapidamente. Na flotação catiônica de silicatos são relevantes os seguintes fatores (SMITH; AKHTAR, 1976):

- a interação entre o mineral e o coletor tem grande importância;

- cadeias longas são necessárias para os coletores, pelo menos 10 carbonos devem estar presentes na cadeia de hidrocarbonetos;

- é suficiente uma adição moderada de coletor;

- a ligação entre coletor e mineral parece ser menos forte, mesmo que o ângulo de contato seja grande; 
- é necessário um tempo, geralmente curto, de condicionamento antes da flotação;

- há sensibilidade para lamas e frações mais finas;

- os coletores, aminas, usualmente têm poder espumante;

- a seletividade de coletores catiônicos para minerais específicos é, geralmente, pobre.

Historicamente, os compostos mais comuns utilizados como reagentes na flotação catiônica do quartzo são os sais de acetato e cloreto de n-dodecylamina $\left(\mathrm{C}_{12} \mathrm{H}_{25} \mathrm{NH}_{2}\right)$, uma mistura de aminas primárias que têm suas porções alifáticas com cadeias de, em torno de, 12 átomos de carbono. Estes sais possuem duas características positivas: primeiro, a porção alifática é composta por uma parte apolar, suficientemente longa para tornar a superfície do quartzo hidrofóbica, com baixa concentração de coletor. Esta propriedade torna o uso destes coletores economicamente viável para a indústria mineral; a segunda característica é a solubilidade destes sais em meio aquoso, o que facilita sua aplicação.

Cronologicamente, as primeiras aminas utilizadas como coletores foram as aminas graxas primárias. Com a inserção do grupo polar $\mathrm{O}-\left(\mathrm{CH}_{2}\right)_{3}$ entre o radical $\mathrm{R}$ e a cabeça polar $\mathrm{NH}_{2}$ da amina primária, surgiram as etermonoaminas e, por fim, as eterdiaminas (ARAUJO et al., 2006). A eficiência, as características (função espumante) e os custos das eteraminas catiônicas foram tão atrativos que estas passaram a ser utilizadas correntemente na flotação seletiva do quartzo.

Muitos estudos sobre a variação da efetividade das aminas com sua estrutura foram reportados na literatura. Contudo, estes estudos foram conduzidos sob variadas condições experimentais, tornando difíceis as comparações. Como resultado, foi conduzida por Bleier; Goddard e Kulkarni (1976) uma investigação sistemática em toda estrutura do coletor na microflotação de quartzo para $\circ \mathrm{pH}$ variando de 7 a 11 , as faixas mais comumente utilizadas na prática. $\mathrm{O} \mathrm{pH}$ que resultou em maior flotabilidade de quartzo para aminas primárias e secundárias foi, aproximadamente, 10,75. Para aminas terciárias, o pH ótimo foi de 9,50.

A Clariant (CLARIANT, 2006) produz uma variedade de surfatantes catiônicos, série Flotigam (eteraminas, aminas primárias, diaminas graxas, triamina, quaternário de amônio e imidazomolinas). O coletor Flotigam EDA utilizado no presente estudo é uma etermonoamina de cadeia média ramificada, com grau de 
neutralização de 48 a $52 \%$, cuja composição química é: alquilamina neutralizada parcialmente com ácido acético, [R-O- $\left.\left(\mathrm{CH}_{2}\right)_{3}-\mathrm{NH}_{3}\right]^{+} \mathrm{CH}_{3} \mathrm{COO}-$ (CLARIANT, 2001).

Sua escolha foi feita com base na flotação reversa da sílica dos minérios de ferro com eteraminas. Neste caso, a faixa mais adequada de $\mathrm{pH}$ para a flotação é de 9 a 11. A adição de um depressor, como amido gelatinizado com soda, melhora a seletividade e a recuperação do mineral de ferro. Os depressores reagem com os sítios superficiais dos minerais que não se deseja flotar, tornando-os hidrofílicos. $O$ amido, polissacarídeo constituído por duas frações poliméricas, é utilizado como agente depressor desde 1931, quando foi patenteado como depressor seletivo na separação fosfato/quartzo por Lange (MARTINS, 2004, p. 29).

\subsection{ITAMARATI DE MINAS - CBA}

A Companhia Brasileira de Alumínio (CBA) possui minas e uma usina de tratamento de minérios em Itamarati de Minas, MG, cujo minério é objeto do presente estudo. A lavra é feita em três frentes distintas: duas de minério gnáissico, originado da laterização de rochas gnáissicas, em Itamarati de Minas, e uma de minério anfibolítico, proveniente da laterização de rochas anfibolíticas, no município de Descoberto. Esta atividade envolve a recuperação das áreas degradadas, com o plantio da vegetação original.

A usina de beneficiamento, que iniciou suas atividades em 1992 (BERGERMAN, 2003), opera com estes dois tipos de minério. A figura 7 mostra uma visão geral da usina de beneficiamento de Itamarati de Minas. 


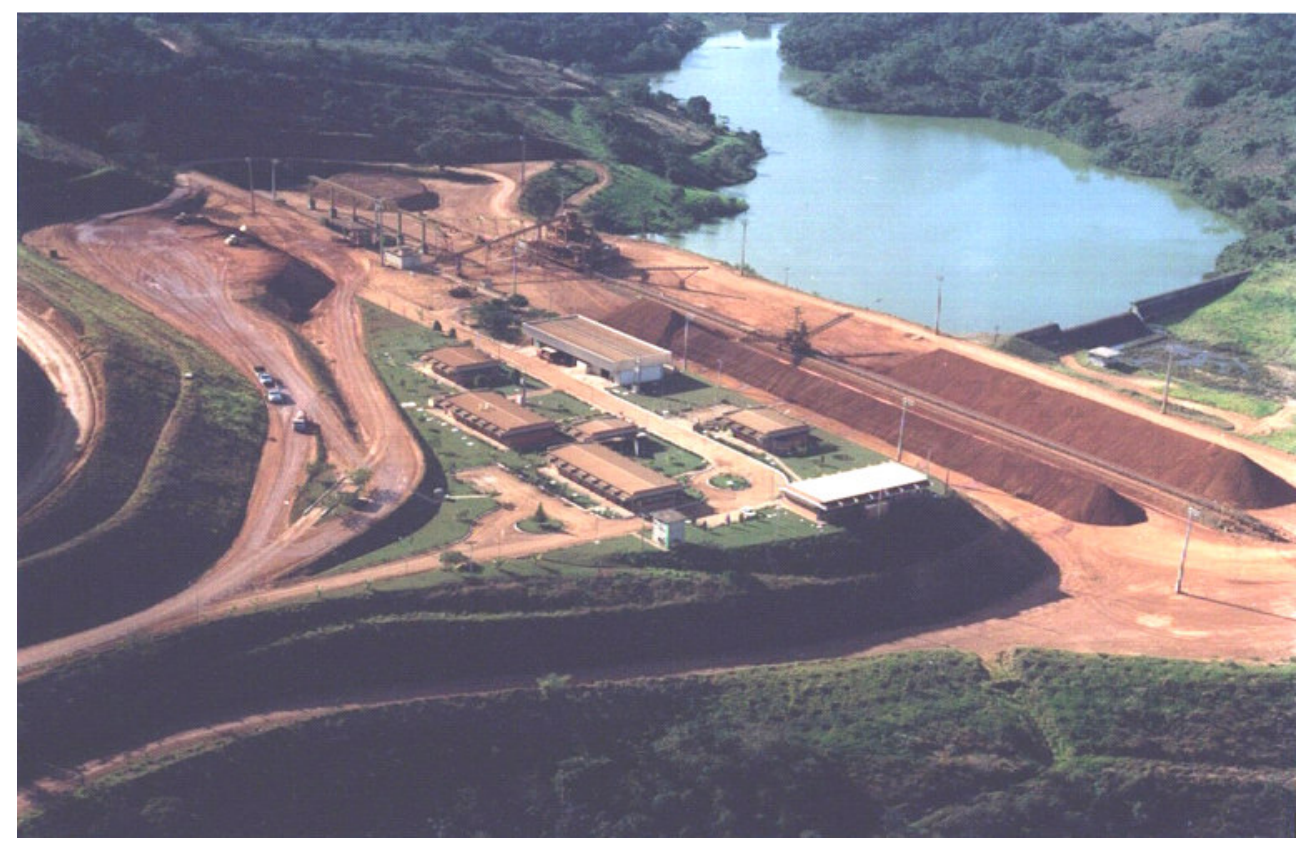

Figura 7 - Usina de beneficiamento de Itamarati de Minas, CBA

A configuração inicial do circuito consistia em britagem primária para redução abaixo de $125 \mathrm{~mm}$ (5"), alimentada por um alimentador de barras elípticas ("wobbler feeder"), desagregação primária em "scruber", peneiramento primário nas malhas de $25 \mathrm{~mm}$ (1") no primeiro "deck" e $6 \mathrm{~mm}$ (1/4") no segundo "deck", britagem secundária do retido em $25 \mathrm{~mm}$, desagregação secundária do produto da britagem secundária mais o retido na malha de $6 \mathrm{~mm}$, peneiramento secundário em malha de $6 \mathrm{~mm}$, o retido sendo produto final. Os passantes do peneiramento primário e secundário eram submetidos ao peneiramento terciário em malha de 1,2 mm ( $n^{\circ} 14$ Tyler), o passante era rejeito da planta e o retido, produto final. Os produtos eram homogeneizados por uma empilhadeira. A recuperação em massa era de $43,5 \%$ e a metalúrgica de $61 \%$, com produção de 30.000 t/mês.

Em 1996, houve a substituição da malha de $25 \mathrm{~mm}$ para $50 \mathrm{~mm}$ no peneiramento primário, reduzindo a geração de finos pela britagem secundária e substituição das malhas de $6 \mathrm{~mm}$, nos peneiramentos primário e secundário, para malha $1,2 \mathrm{~mm}$, eliminando as peneiras terciárias. Os passantes destas peneiras eram deslamados em ciclones de 26", cujo "underflow" sofria peneiramento de alta freqüência para recuperar as partículas acima de $0,297 \mathrm{~mm}$ (no 48 Tyler). A recuperação em massa aumentou para $48,5 \%$ e a metalúrgica para $67 \%$. Com o circuito de finos houve um acréscimo de 4.000 t/mês na produção. 
No início de 1999, os ciclones de 26" foram substituídos por ciclones de 15" de separação mais precisa, aumentando o fluxo de alimentação nas peneiras de alta freqüência, o que resultou na adição de mais 3 peneiras no circuito. As malhas de 0,297 mm ( $n^{\circ} 48$ Tyler) das peneiras de alta freqüência foram substituídas por malhas 0,425 mm ( $n^{\circ} 40$ Tyler). A recuperação de lavagem chegou a 55,5\% e a metalúrgica a $75 \%$. O circuito de finos produziu 10.000 t/mês e produção da usina chegou a 45.000 t/mês.

Até o início de 2000, os dois tipos de minério, anfibolítico e gnáissico, eram beneficiados juntos e os resultados só divergiam na fração abaixo da malha 0,425 $\mathrm{mm}$. Nesta fração, o minério anfibolítico está mais contaminado por minerais de ferro $\left(\mathrm{Fe}_{2} \mathrm{O}_{3}\right)$ e titânio $\left(\mathrm{TiO}_{2}\right)$, já o gnáissico apresenta maior quantidade de sílica $\left(\mathrm{SiO}_{2}\right)$. Devido a estas diferenças, os dois minérios deviam ser tratados separadamente para o aproveitamento da fração fina (OBA, 2000). Com o objetivo de mostrar a viabilidade do aproveitamento destes finos, Chaves (2000) realizou estudos com a implantação de uma usina piloto junto à industrial em Itamarati de Minas.

Em 2000, foi desenvolvida a tecnologia de processo para recuperar a bauxita nas frações abaixo da malha 0,425 $\mathrm{mm}$. Testes em escala piloto mostraram que a recuperação de bauxita era viável para o minério anfibolítico, já que os contaminantes de ferro e titânio podiam ser separados pelos métodos densitário e magnético. O minério gnáissico, por ter teores muito altos de sílica nestas frações, não podia ser separado por estes métodos.

Para o minério anfibolítico, os passantes das peneiras de alta freqüência são submetidos a uma bateria de ciclones de 6", que fazem uma separação em 0,062 mm ( $n^{\circ} 250$ Tyler), eliminando a fração menor com alto teor de sílica. O "underflow" dos ciclones segue para duas baterias de espirais concentradoras ("rougher" e "cleaner"), onde parte dos minerais ferrosos são retirados, reduzindo a alimentação do separador magnético de carrossel, que tem alto valor de investimento. A fração magnética segue para um desaguamento em classificador espiral e é empilhada, os médios são recirculados e os não-magnéticos são submetidos a um adensamento em um cone desaguador, passando por uma peneira desaguadora e em seguida, gerando o produto final. A recuperação em massa chega a $60 \%$ e a metalúrgica a $90 \%$, para o anfibolítico. A usina é alimentada alternando os dois tipos de minérios e a recuperação de lavagem chega a 59\%. 
A figura 8 mostra a bateria de espirais concentradoras e a figura 9 ilustra 0 atual fluxograma da usina de beneficiamento de Itamarati de Minas.

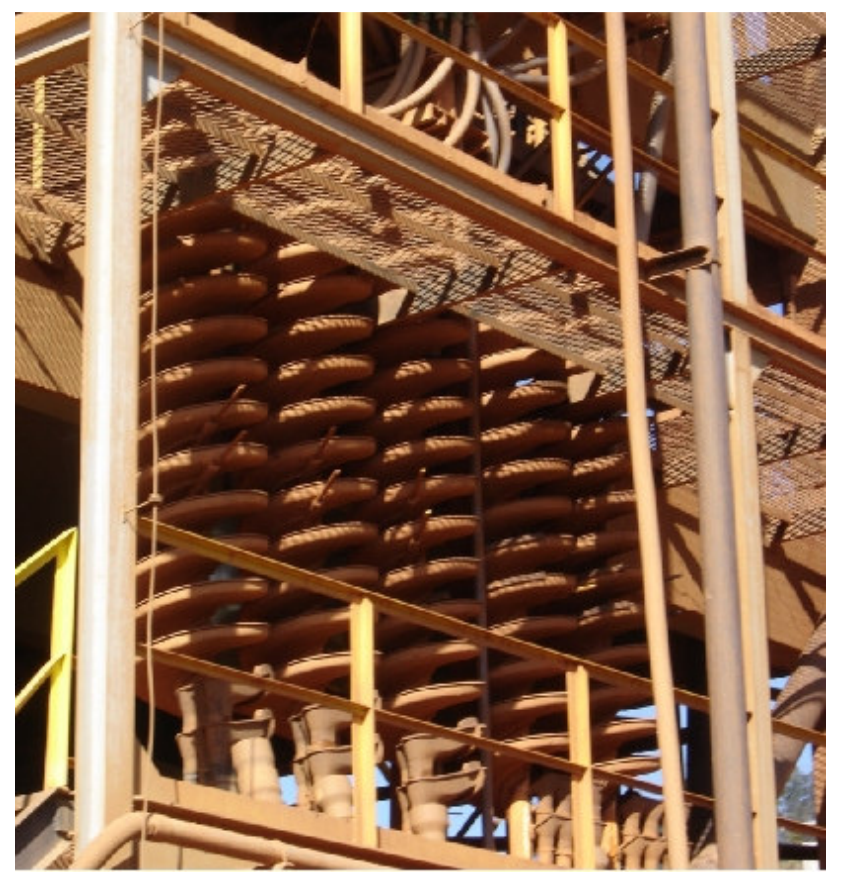

Figura 8 - Espirais concentradoras do circuito de finos do minério anfibolítico 


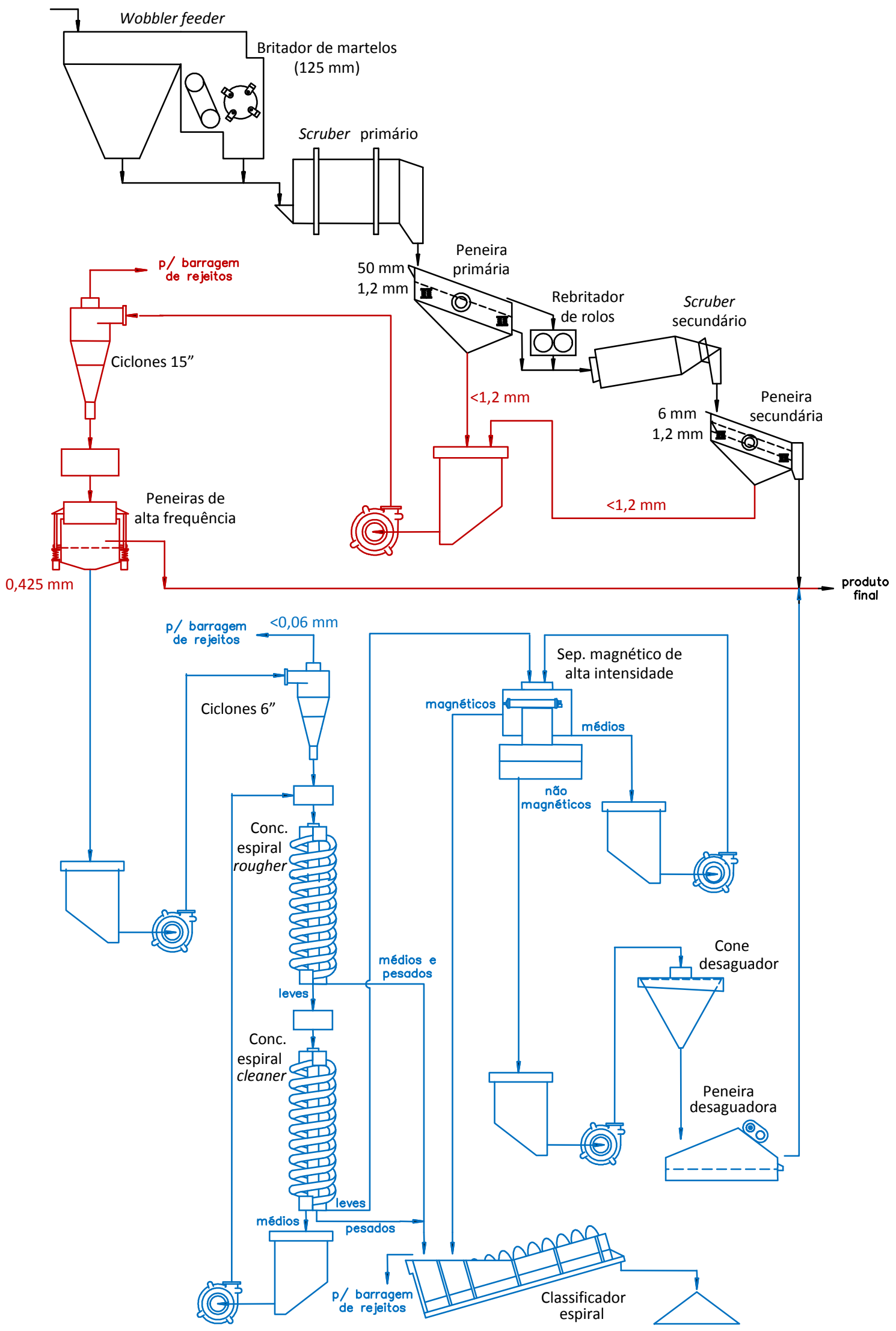

Figura 9 - Fluxograma atual do beneficiamento em Itamarati de Minas 
Esta linha de aproveitamento da fração fina serve apenas para o minério anfibolítico, visto suas diferenças em relação ao gnáissico. Os rejeitos gerados são: "overflow" do ciclone de 15" e de 6", e "overflow" do classificador espiral. O "underflow" deste último são os minerais pesados de ferro e titânio, que formam uma pilha. Quando o minério gnáissico é beneficiado, o "underflow" do ciclone de 6" passa a ser um rejeito também.

O aproveitamento do rejeito, "underflow" do ciclone de 6", através da flotação reversa da sílica, é a continuação de uma linha de pesquisa que visa:

- viabilizar técnica e economicamente o aproveitamento de todos os resíduos gerados;

- aumentar a vida útil da barragem de contenção de rejeitos; e

- o completo aproveitamento do minério.

Segundo Bergerman (2003), os rejeitos podem ser utilizados como:

- $\mathrm{Fe}_{2} \mathrm{O}_{3}$ e $\mathrm{TiO}_{2}$ - corretivo para a fabricação de cimento portland, resultante da moagem de clínquer, obtido pelo aquecimento até fusão incipiente (30\% da fase líquida) de mistura de calcário e argila dosada e homogeneizada. Em quantidades adequadas $0 \mathrm{TiO}_{2}$ age como fundente do clínquer, diminuindo a temperatura de trabalho do forno e, assim, economizando combustível e aumentando a vida útil do refratário;

- Lamas - fabricação de cerâmica vermelha, com boa resistência e bons resultados nos índices analisados.

O quartzo $\left(\mathrm{SiO}_{2}\right)$ pode ser utilizado como areia para construção civil, dada sua granulometria e composição mineralógica. 


\section{MATERIAIS E MÉTODOS}

\subsection{ATIVIDADES DESENVOLVIDAS}

Para dar início ao trabalho experimental em laboratório, partiu-se dos resultados obtidos por Freitas (2004) no trabalho que originou a linha de pesquisa sobre o aproveitamento através da flotação de um material considerado rejeito do beneficiamento de bauxita na usina de Itamarati de Minas da CBA. Como o estudo anterior não obteve sucesso com a flotação da bauxita, que estava em menor quantidade, a flotação reversa da sílica foi o caminho escolhido. Seus ensaios envolveram variações de reagentes, de $\mathrm{pH}$ e adição de depressor. Os melhores resultados foram obtidos com:

- coletor: Flotigam EDA (300 g/t), etermonoamina de cadeia média ramificada;

- depressor: solução a $2 \%$ de amido gelatinizado com soda cáustica na proporção 5:1 (300 g/t); e

- $\mathrm{pH}: 10$.

O teor de alumina aproveitável no produto final, após separação magnética para eliminar os óxidos de ferro e titânio, foi de $42 \%$.

$\mathrm{Na}$ mesma linha, este trabalho teve início com experimentos sistemáticos de flotação realizados no Laboratório de Tratamento de Minérios e Resíduos Industriais (LTM) do Departamento de Engenharia de Minas e de Petróleo da Escola Politécnica da Universidade de São Paulo (EPUSP) para otimização do processo. A dosagem de Flotigam EDA foi variada, mantendo-se fixos o $\mathrm{pH}$ e a dosagem de depressor. Em seguida variou-se a dosagem de depressor, mantendo constante 0 coletor e o pH. Definidas as dosagens ótimas dos reagentes, partiu-se para o experimento de flotação com as etapas "cleaner" e "scavenger" para balanço de massa, simulando um circuito contínuo. Até então, as amostras utilizadas foram as originadas da amostragem feita pela CBA em 2004, época dos trabalhos de Freitas (2004). 
Para validar o estudo, foi feita uma nova amostragem na usina de Itamarati de Minas, em julho de 2005. Então, com a nova amostra, foi feita a flotação com recirculação de produtos para simular um circuito. Para todos os concentrados finais foram feitas separações magnéticas de média intensidade para separar os óxidos de ferro e titânio da bauxita.

Resumindo, foi adotado o seguinte método: determinação das dosagens ótimas de coletor e depressor, experimentos de flotação com "cleaner" e "scavenger", nova amostragem, preparação das novas amostras, caracterização das novas amostras, experimentos de flotação com recirculação, análise química após cada experimento e separação magnética de média intensidade para os deprimidos finais.

Os experimentos seguiram o padrão descrito abaixo para as amostras colhidas em 2004, já abaixo de 0,21 mm (passante na malha no 65 Tyler), quarteadas e deslamadas (acima de $10 \mu \mathrm{m}$ ):

- determinação da massa, do volume e da densidade de polpa $\left(m_{p}, V_{p}\right.$ e $\left.\rho_{\mathrm{p}}\right)$;

- acerto da porcentagem de sólidos em $40 \%$, calculada pela equação 7 :

$$
\% \text { sol }=100 \cdot \frac{\left(\rho_{p}-1\right)}{\rho_{p}} \cdot \frac{\rho_{S}}{\rho_{S}-1}
$$

onde $\rho_{p}$ e $\rho_{s}$ são os pesos específicos da polpa e dos sólidos, para a bauxita $\rho_{\mathrm{s}}=2,7$;

- determinação da massa de sólidos $\left(m_{S}=m_{p} . \%\right.$ sol $)$; e

- cálculo da quantidade de solução de amido e coletor de acordo com a concentração.

As amostras de julho de 2005 foram peneiradas na malha de $210 \mu \mathrm{m}$, deslamadas em $10 \mu \mathrm{m}$, homogeneizadas e quarteadas em alíquotas de $500 \mathrm{~g}$. As quantidades de reagentes foram calculadas com base nesta massa.

A flotação mecânica de bancada feita em máquina Denver, figura 10, seguiu o mesmo procedimento para todas as amostras, qual seja:

- condicionar 5 minutos com solução de amido $2 \%$ a $40 \%$ de sólidos;

- condicionar 2 minutos com coletor Flotigam EDA (6,839 x 10-3 g/gota);

- completar a cuba de 1500 ml com água;

- acertar o pH em 10; 
- abrir a válvula de ar;

- completar o nível da célula com água em pH 10 quando necessário;

- determinar o tempo de flotação $\left(\mathrm{t}_{\mathrm{f}}\right)$, até a exaustão da espuma.

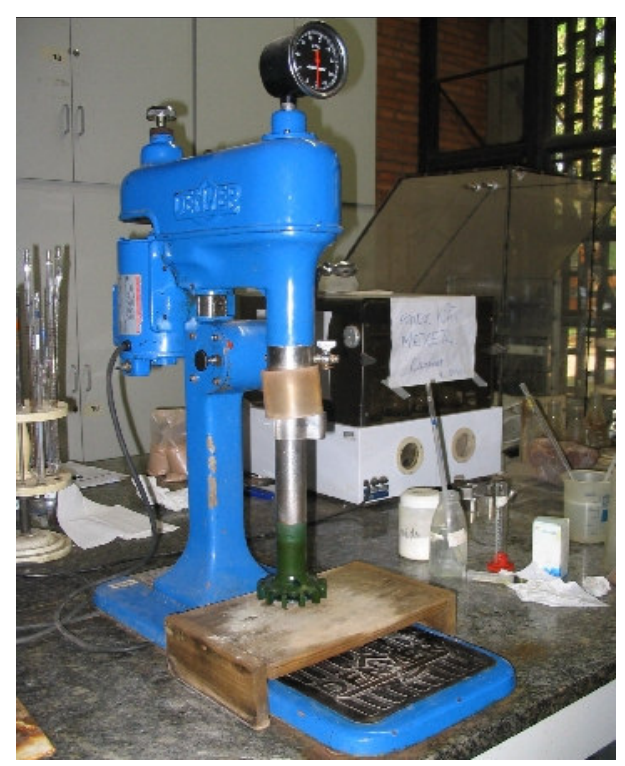

Figura 10 - Máquina de flotação Denver

A solução a $2 \%$ de amido gelatinizado tinha que ser preparada no mesmo dia da flotação para prevenir eventual deterioração do produto. A amina era utilizada em gotas em uma seringa de plástico previamente calibrada.

Os produtos da flotação foram denominados flotado (sílica) e deprimido (bauxita e óxidos de ferro e titânio). A simbologia adotada é mostrada na figura 11:

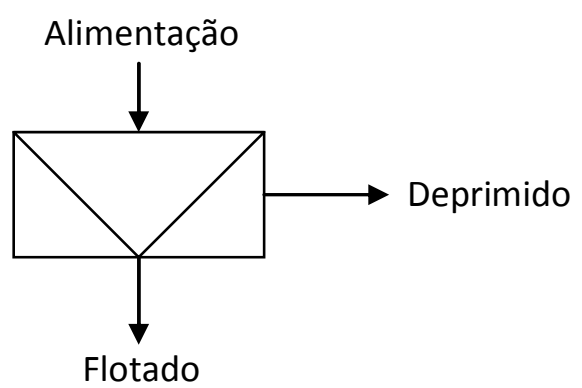

Figura 11 - Representação da flotação e seus produtos 


\subsection{DETERMINAÇÃO DA DOSAGEM ÓTIMA DOS REAGENTES}

Abaixo descreve-se a determinação das dosagens de reagentes que proporcionaram maiores teores de alumina aproveitável $\left(\mathrm{Al}_{2} \mathrm{O}_{3 a p}\right)$ e recuperações de massa do concentrado da flotação (deprimido).

\subsubsection{Coletor}

No primeiro experimento realizaram-se cinco ensaios variando a dosagem de coletor Flotigam EDA em 200, 250, 300, 350 e $400 \mathrm{~g} / \mathrm{t}$, mantendo a dosagem do depressor amido em $300 \mathrm{~g} / \mathrm{t}$ e o pH igual a 10, com adição de solução de $\mathrm{NaOH}$ a $10 \%$.

O coletor era colocado em gotas de seringa de injeção e, para calcular a quantidade delas, era necessário saber a massa de uma gota; neste caso, de acordo com a agulha utilizada, uma gota do Flotigam EDA pesava $6,839 \times 10^{-3} \mathrm{~g}$. Para as respectivas concentrações foram utilizadas 9, 11, 13, 13 e 17 gotas. As massas de minério não eram constantes.

Os produtos, flotados (F1, F2, F3, F4 e F5) e deprimidos (D1, D2, D3, D4 e D5), foram secos na estufa a $100^{\circ} \mathrm{C}$ e pesados. Os deprimidos sofreram separação magnética em imã de mão de terras raras, originando deprimidos magnéticos (Dmag) e não-magnéticos (Dñ-mag). Depois de determinadas suas massas, todos os produtos foram reduzidos no quarteador Jones e as alíquotas seguiram para análise química no laboratório da CBA, em Itamarati de Minas (MG).

\subsubsection{Depressor}

O segundo experimento foi semelhante ao anterior, mas desta vez foram variadas as dosagens do depressor (amido) a $2 \%$, mantendo o coletor em $300 \mathrm{~g} / \mathrm{t} \mathrm{e}$ o pH igual a 10, com adição de $\mathrm{NaOH}$ a $10 \%$. 
Por ser utilizada uma solução de amido, o depressor era dosado em volume. Para calcular o volume necessário foi utilizada a relação: $100 \mathrm{ml}$ de solução de amido a $2 \%$ equivale a $1 \mathrm{~g}$ de amido (densidade $=0,5 \mathrm{~g} / \mathrm{ml}$ ). Assim, foram utilizados respectivamente $0,4,5 \mathrm{ml}, 7,1 \mathrm{ml}, 8,6 \mathrm{ml}$ e $14,7 \mathrm{ml}$ de solução, equivalentes às seguintes dosagens $0,200,300,400$ e $600 \mathrm{~g} / \mathrm{t}$. Os produtos flotados (F6, F7, F8, F9 e F10) e deprimidos (D6, D7, D8, D9 e D10) seguiram os mesmos procedimentos descritos anteriormente.

\subsection{FLOTAÇÃO COM “CLEANER" E "SCAVENGER"}

Definidos $\mathrm{o} \mathrm{pH}$ e as dosagens ótimas do coletor e do depressor, individualmente e sem considerar potenciais efeitos sinergéticos entre estes, seguiuse o experimento de flotação com as etapas "cleaner" e "scavenger" para estabelecer o balanço de massas. As flotações anteriores haviam sido feitas em uma etapa única, a denominada "rougher". Desta vez foi ensaiado o circuito clássico de flotação com as etapas "rougher", "cleaner" e "scavenger". Por se tratar de flotação reversa, convencionou-se chamar de "cleaner" a flotação do flotado "rougher" e de "scavenger" a flotação do deprimido "rougher". A figura 12 ilustra o circuito.

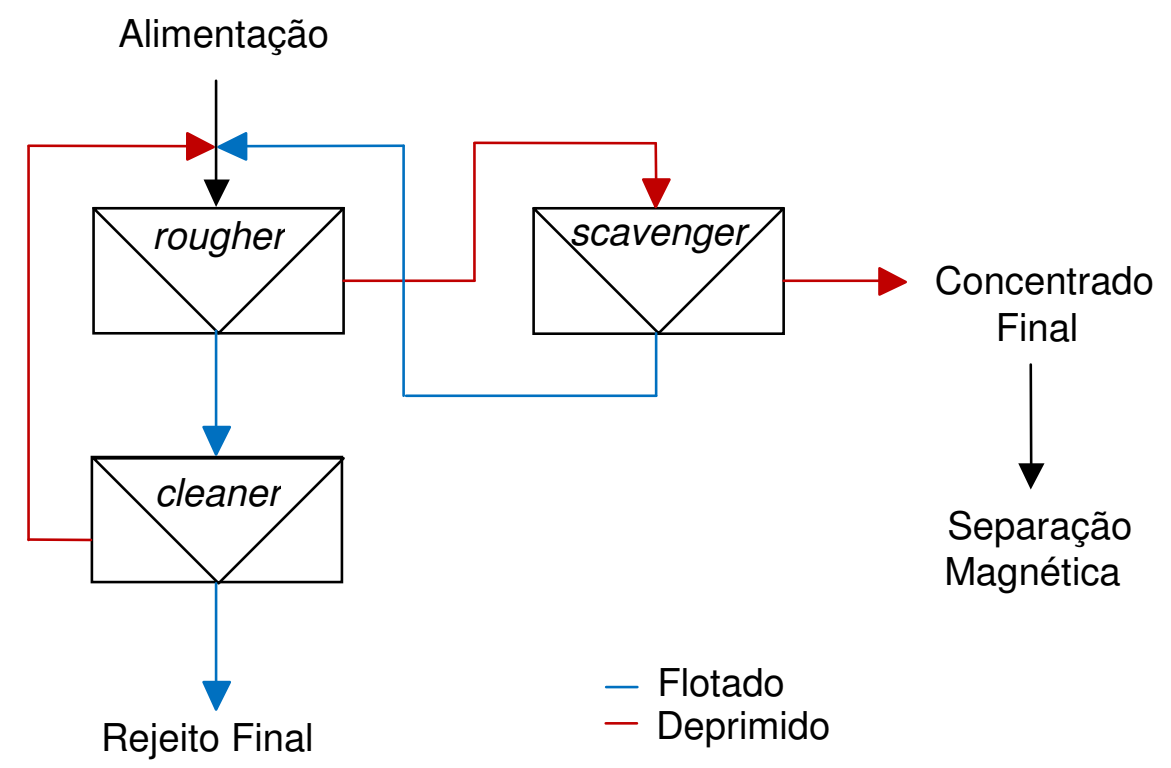

Figura 12 - Circuito de flotação 
Na etapa "rougher" I foram utilizadas duas amostras de minério deslamado para cada uma das três flotações, com $300 \mathrm{~g} / \mathrm{t}$ do coletor Flotigam EDA e de depressor amido $2 \%$, o pH manteve-se em 10 . Obtiveram-se três deprimidos e três flotados identificados como mostra a figura 13.
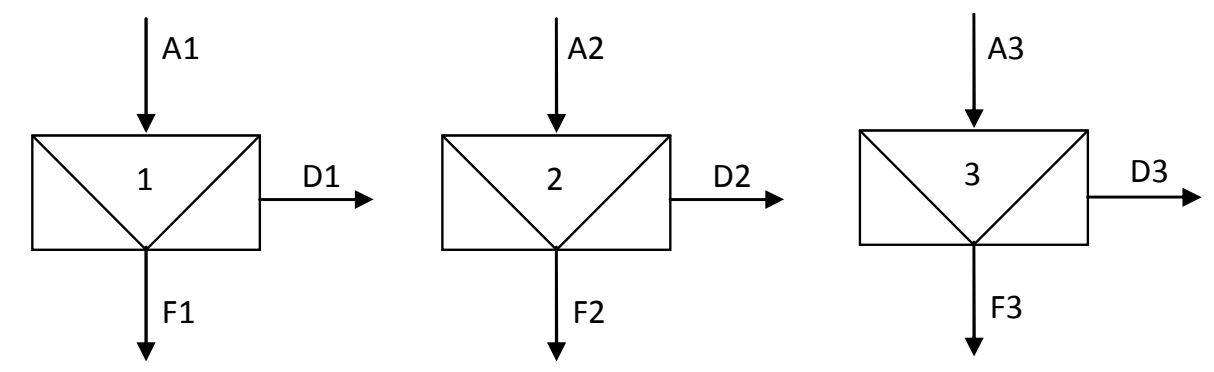

Figura 13 - Etapa "rougher" I

A etapa "scavenger" I foi alimentada com os deprimidos D1, D2 e D3, mais $150 \mathrm{~g} / \mathrm{t}$ de coletor, resultando no flotado e deprimido D4. A etapa "cleaner" I foi alimentada com os flotados F1, F2 e F3, sem adição de coletor, resultando nos flotado e deprimido F5 e D5. Pelo circuito mostrado na figura 14, D4 é o concentrado final e F5 o rejeito final. Assim, D5 e F4 alimentam a etapa "rougher" II, com adição de $150 \mathrm{~g} / \mathrm{t}$ de coletor. O flotado F6 alimentou o "cleaner" II, resultando nos flotado e deprimido F7 e D7. Já o deprimido D6 não foi para o "scavenger" II, pois não havia massa suficiente. 


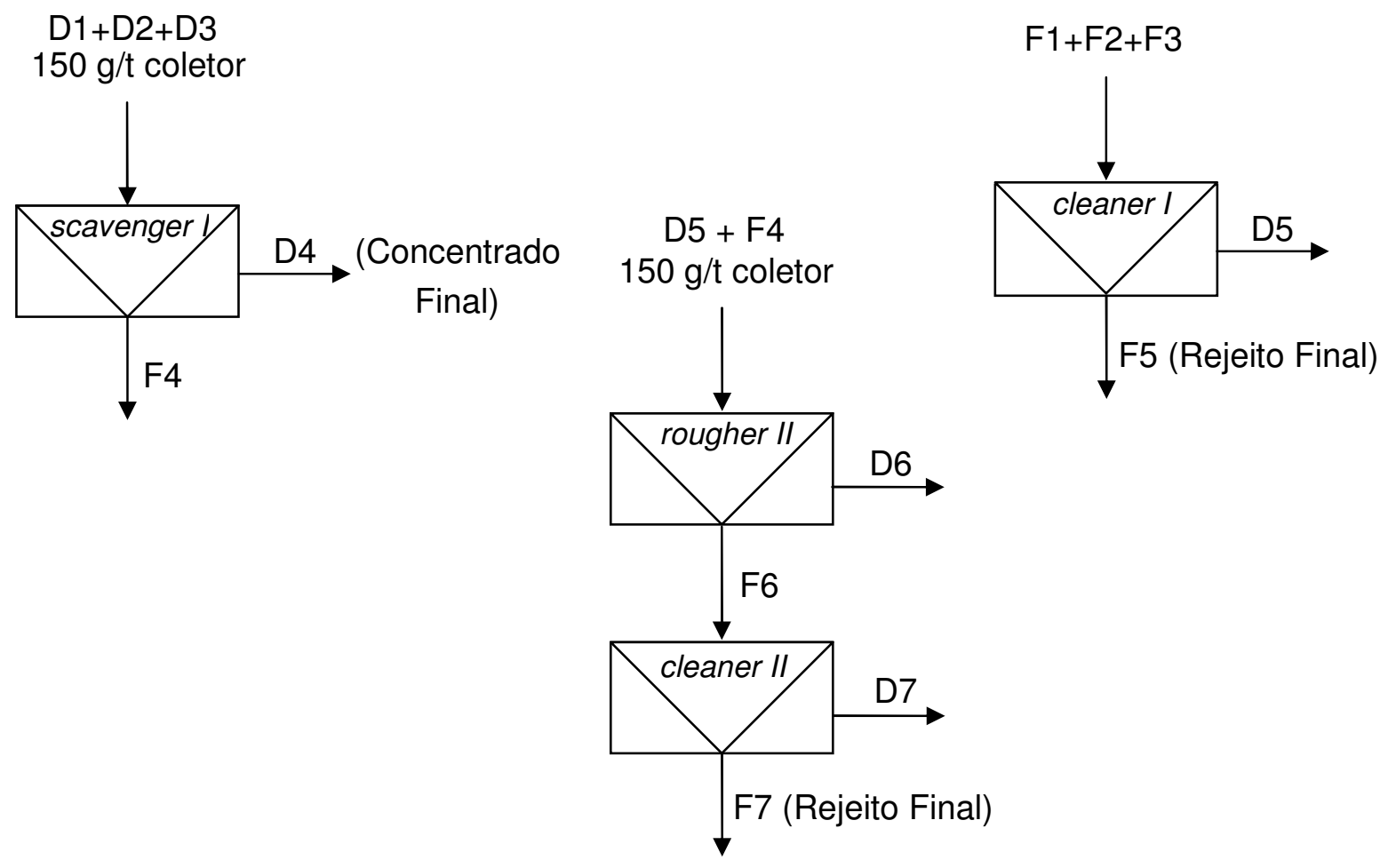

Figura 14 - Flotação com "cleaner" e "scavenger"

O concentrado final D4 seguiu para a separação magnética de média intensidade com o imã de terras raras. Os produtos D4 magnético e não-magnético, D6, D7, F5 e F7 foram quarteados e enviados para a análise química no Laboratório da CBA.

\subsection{AMOSTRAGEM}

As amostras do rejeito de minério gnáissico ("underflow" do ciclone de 6") foram obtidas durante uma campanha de amostragem liderada pelo Prof. Arthur Pinto Chaves, na usina de beneficiamento de Itamarati de Minas, em julho de 2005. Ao longo de uma semana foi formada a amostra de 200 I desaguada do "underflow" do ciclone de 6" do minério gnáissico de Itamarati, em dois tambores de $100 \mathrm{l}$. As figuras 15 e 16 mostram a bateria dos ciclones de 6 " e os tambores com as amostras. 


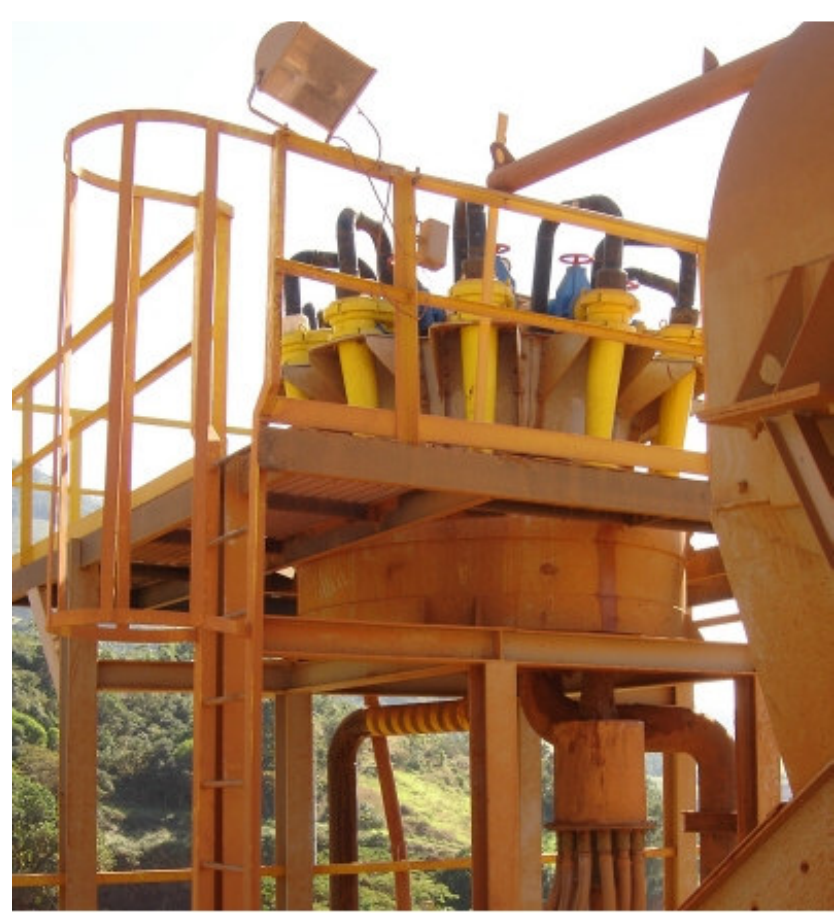

Figura 15 - Bateria dos ciclones de 6"

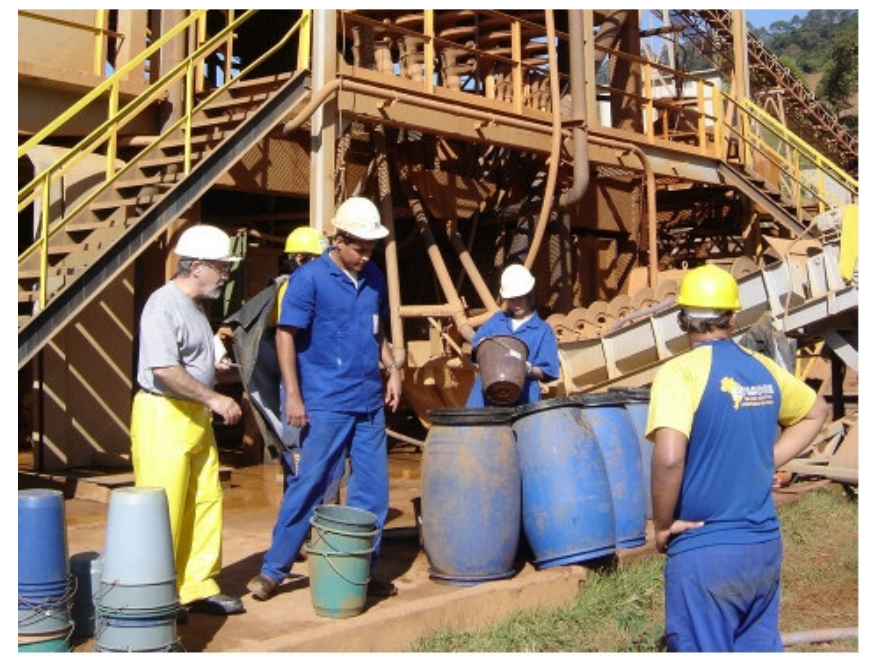

Figura 16 - Tambores com as amostras coletadas

A amostragem foi sistemática, de hora em hora, em um período de, aproximadamente, 5 horas por dia, durante cinco dias efetivos de produção. Outras amostras, de outros pontos, também foram retiradas ao longo de três semanas, para utilização em outros estudos. Os tambores foram devidamente lacrados, identificados e enviados ao LTM. 


\subsubsection{Preparação das amostras}

As amostras do "underflow" do ciclone de 6" foram retiradas dos dois tambores, colocadas em bandejas e secas na estufa a $100{ }^{\circ} \mathrm{C}$. Após a secagem, foi feita uma pilha de homogeneização, as pontas foram retomadas e a pilha foi quarteada em alíquotas de 5 e $10 \mathrm{~kg}$. Com uma alíquota de $10 \mathrm{~kg}$ foi feita uma outra pilha de homogeneização, com retomada das pontas e separadas alíquotas para análise química de cabeça e análise granulométrica nas malhas $0,42,0,21,0,149$, 0,104, 0,074 e 0,037 mm ( $n^{\circ}$ 35, 65, 100, 150, 200 e 400 Tyler). Com o que restou desta segunda pilha, foi feito um peneiramento na malha $0,21 \mathrm{~mm}$ (no 65 Tyler), já que partículas maiores que $0,21 \mathrm{~mm}$ não são flotadas, provavelmente por apresentarem maior massa e descolarem mais facilmente das bolhas de ar (descoleta). O material passante em $210 \mu \mathrm{m}$ seguiu para a deslamagem no ciclone de corte de $5 \mu \mathrm{m}$ e posteriormente no de $10 \mu \mathrm{m}$. A flotação do minério com lama foi feita para confirmar a necessidade da deslamagem.

\subsection{CARACTERIZAÇÃO DAS AMOSTRAS}

As amostras do "underflow" (UF) do ciclone de 6", originadas da amostragem da CBA em 2004 e utilizadas nos primeiros experimentos de flotação, foram caracterizadas por análise química por faixa granulométrica, nas malhas $0,42,0,21$, 0,149, 0,104 e 0,037 mm ( $n^{\circ}$ 35, 65, 100, 150 e 400 Tyler).

Com as novas amostras do rejeito (UF do ciclone de 6"), coletadas em julho de 2005, foram feitas: análise química da amostra de cabeça (após homogeneização e redução), por faixa granulométrica, e análise granulométrica a úmido nas malhas 0,42, 0,21, 0,149, 0,104, 0,074 e 0,037 mm (no 35, 65, 100, 150, 200 e 400 Tyler). Adicionalmente, foi feita uma difratometria de raios $X$, uma análise química semiquantitativa por espectrometria de fluorescência de raios $X$ e uma microscopia eletrônica de varredura (MEV) no Laboratório de Caracterização Tecnológica (LCT) do Departamento de Engenharia de Minas e de Petróleo da Universidade de São Paulo. 


\subsection{FLOTAÇÃO COM RECIRCULAÇÃO DE PRODUTOS}

Mantendo $0 \mathrm{pH}$ de 10 e as dosagens de coletor e depressor em $300 \mathrm{~g} / \mathrm{t}$, foi feito o último e mais completo experimento do presente estudo. Foi a tentativa de simulação da flotação em uma usina, com recirculação de produtos e nova alimentação. Elaborou-se um circuito com cinco etapas "rougher", "cleaner" e "scavenger" (quando se estabilizou o circuito), esquematizados como na flotação mostrada no item 3.3. Os produtos são identificados como flotado "cleaner" (FLCLN), flotado "scavenger" (FLSCN), deprimido "cleaner" (DCLN) e deprimido "scavenger" (DSCN), onde $\mathrm{N}$ é o número de cada etapa. A alimentação (A) é nova a cada etapa. A figura 17 mostra em seqüência as etapas "rougher", "cleaner" e "scavenger". A figura 18 ilustra o ciclo executado.

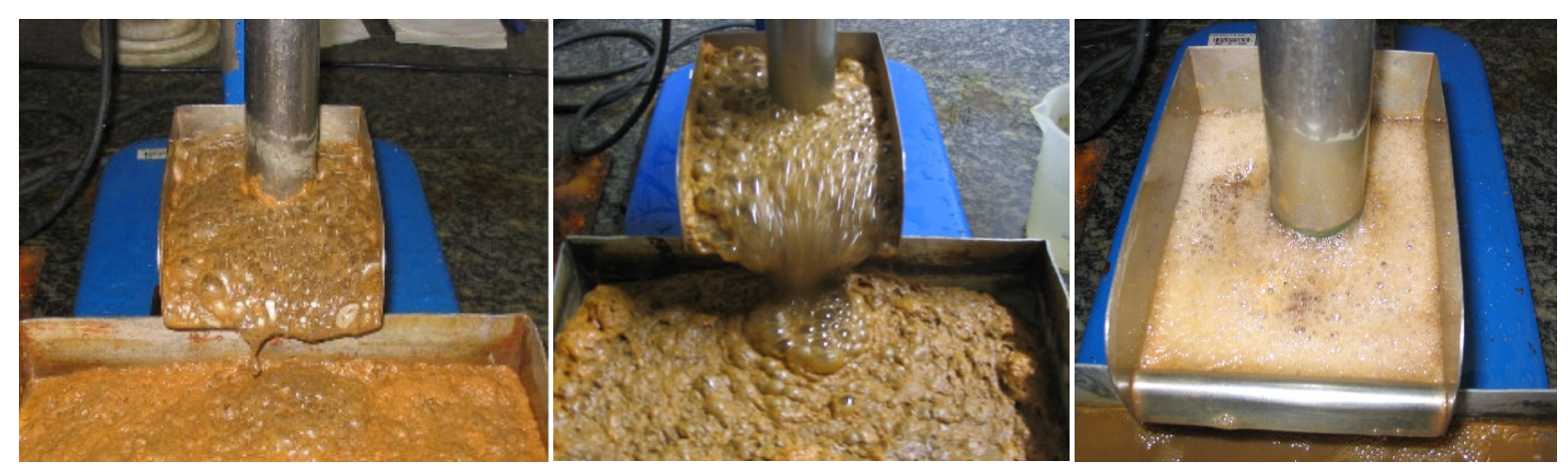

Figura 17 - Etapas "rougher", "cleaner" e "scavenger" da flotação reversa 


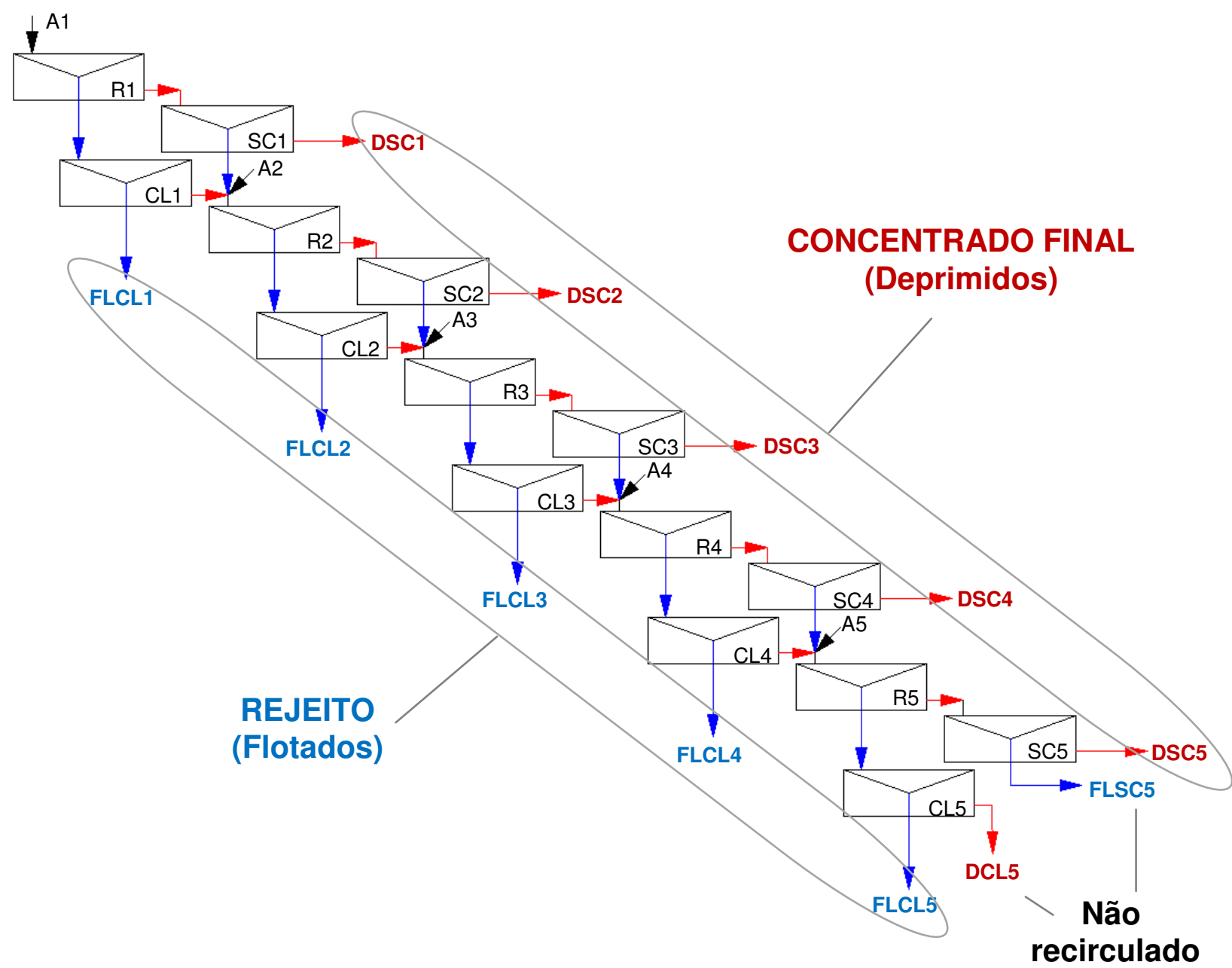

Figura 18 - Flotação com recirculação de produtos

Todos os deprimidos da etapa "scavenger" (DSC) são produtos finais, portanto, após a secagem em estufa a $100^{\circ} \mathrm{C}$, foram pesados separadamente e homogeneizados em uma pilha prismática alongada, por duas vezes, com retomada das pontas, sendo então quarteados e divididos em três alíquotas. A primeira foi para análise química, a segunda para a separação magnética de média intensidade com imã de terras raras e a terceira ficou de arquivo.

Os flotados da etapa "cleaner" (FLCL) são rejeitos finais, após a secagem em estufa a $100^{\circ} \mathrm{C}$ e a pesagem separada de cada um, também foram homogeneizados duas vezes em pilha prismática e quarteados. De cinco alíquotas, uma seguiu para análise química e as outras ficaram de arquivo.

Os produtos da flotação com recirculação de produtos foram fotografados em lupa. 


\subsection{ANÁLISE QUÍMICA}

Os produtos e rejeitos foram enviados para a análise química no Laboratório Químico da CBA em Itamarati de Minas. A análise foi feita com ataque por soda cáustica para a alumina aproveitável e para a sílica reativa. Para o óxido de ferro e para a sílica total e insolúvel, o ataque foi ácido em via úmida. Foram determinados os teores de $\mathrm{SiO}_{2}$ total, $\mathrm{SiO}_{2}$ reativa, $\mathrm{SiO}_{2}$ insolúvel, $\mathrm{Fe}_{2} \mathrm{O}_{3}$ e $\mathrm{Al}_{2} \mathrm{O}_{3}$ aproveitável. É, portanto, uma análise técnica, mais que uma análise química.

\subsection{SEPARAÇÃO MAGNÉTICA}

Os deprimidos finais com alto teor de alumina e óxidos de ferro e titânio seguiram para a separação magnética de média intensidade. Esta separação foi feita utilizando-se um imã de terras raras. O material era colocado sobre uma folha de papel branca, o imã ficava dentro de um saco plástico, então este era passado sobre o material, as partículas magnéticas eram atraídas ao imã enquanto as nãomagnéticas permaneciam sobre a folha. Assim foram separados os minerais de ferro e titânio (magnéticos) e a bauxita (não-magnética). 


\section{RESULTADOS}

Segundo as especificações da CBA, a bauxita para fabricação de alumina deve ter:

granulometria abaixo de $50 \mathrm{~mm}(2 ")$;

teor de $\mathrm{Al}_{2} \mathrm{O}_{3}$ aproveitável acima de $40 \%$;

teor de $\mathrm{SiO}_{2}$ reativa abaixo de $4 \%$;

teor de $\mathrm{Fe}_{2} \mathrm{O}_{3}$ abaixo de $18 \%$.

\subsection{DETERMINAÇÃO DA DOSAGEM ÓTIMA DOS REAGENTES}

Os resultados da determinação das dosagens otimizadas de reagentes seguem abaixo.

\subsubsection{Coletor}

A tabela 3 e o gráfico 3 mostram a variação das recuperações e teores de $\mathrm{Al}_{2} \mathrm{O}_{3}$ aproveitável em função da concentração do coletor Flotigam EDA, mantendo a concentração de depressor amido constante, assim como o pH. $\mathrm{O}$ ensaio 2 não foi considerado, pois o tempo de flotação foi anômalo em relação aos outros ensaios.

Os teores e distribuições de todos os produtos são apresentados no APÊNDICE A.

Tabela 3 - Recuperações e teores em função da dosagem de coletor

\begin{tabular}{c|c|c|c|c|c|c}
\hline Experimento & $\begin{array}{c}\text { Coletor } \\
(\mathbf{g} / \mathbf{t})\end{array}$ & $\begin{array}{c}\text { Depressor } \\
(\mathbf{g} / \mathbf{t})\end{array}$ & $\mathbf{p H}$ & $\begin{array}{c}\mathbf{R}_{\text {massa }} \\
(\%)\end{array}$ & $\begin{array}{c}\mathbf{R A I}_{2} \mathbf{O}_{\text {3aprov }} \\
(\%)\end{array}$ & $\begin{array}{c}\mathbf{A l}_{2} \mathbf{O}_{\text {3aprov }} \\
(\%)\end{array}$ \\
\hline 1 & 192,9 & 300 & 10 & 33,8 & 72,7 & 22,9 \\
3 & 299,1 & 300 & 10 & 30,6 & 72,9 & 24,6 \\
4 & 360,4 & 300 & 10 & 33,1 & 70,4 & 24,6 \\
5 & 411,0 & 300 & 10 & 30,5 & 76,2 & 24,6 \\
\hline
\end{tabular}




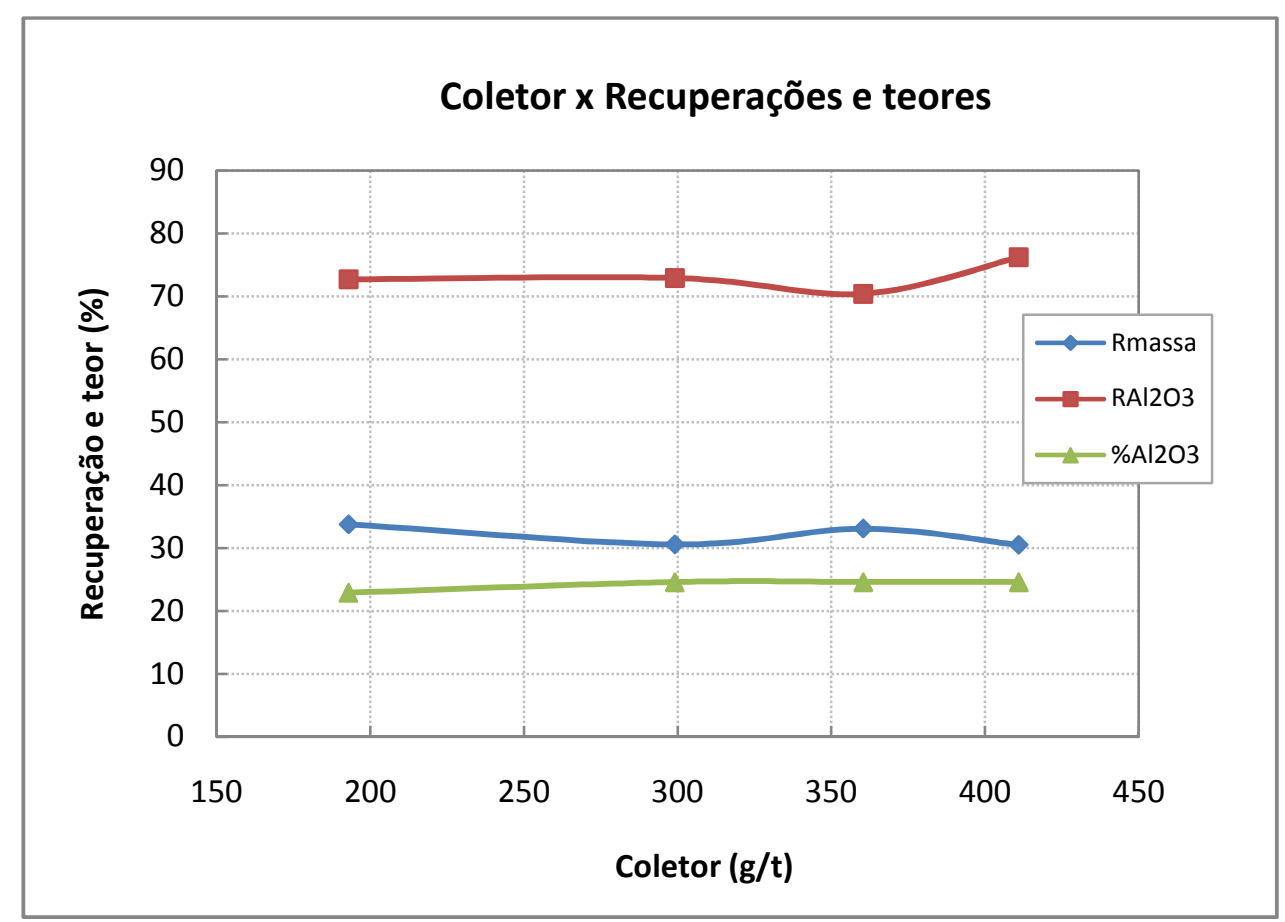

Gráfico 3 - Recuperações e teores de alumina em função da variação da concentração de coletor

De acordo com o gráfico 3, observa-se:

- a recuperação em massa do deprimido diminui com o aumento da concentração de coletor;

- a recuperação de $\mathrm{Al}_{2} \mathrm{O}_{3}$ aproveitável no deprimido permanece praticamente constante $(72,9 \%)$ até a concentração de $300 \mathrm{~g} / \mathrm{t}$ de coletor, então ocorre uma leve queda e um aumento em torno de 400 $\mathrm{g} / \mathrm{t}(76,2 \%)$;

- o teor de $\mathrm{Al}_{2} \mathrm{O}_{3}$ aproveitável atinge o máximo em $300 \mathrm{~g} / \mathrm{t}(24,6 \%)$, permanecendo constante acima disso. Vale salientar que, após a separação magnética do concentrado final, o teor de alumina aproveitável sobe para $46,7 \%$. O teor de $\mathrm{SiO}_{2}$ reativa é $1,1 \%$ e de $\mathrm{Fe}_{2} \mathrm{O}_{3}$ é 9,7\%, portanto, dentro das especificações; e

- a dosagem ótima de coletor determinada foi de $300 \mathrm{~g} / \mathrm{t}$. 


\subsubsection{Depressor}

A tabela 4 e o gráfico 4 mostram a variação das recuperações e teores de $\mathrm{Al}_{2} \mathrm{O}_{3}$ aproveitável em função da concentração do depressor (amido), mantendo a concentração do coletor Flotigam EDA em $300 \mathrm{~g} / \mathrm{t}$ e o pH em 10. Os teores e distribuições de todos os produtos são apresentados no APÊNDICE B.

Tabela 4 - Recuperações e teores em função da dosagem de depressor

\begin{tabular}{c|c|c|c|c|c|c}
\hline Experimento & $\begin{array}{c}\text { Coletor } \\
(\mathbf{g} / \mathbf{t})\end{array}$ & $\begin{array}{c}\text { Depressor } \\
(\mathbf{g} / \mathbf{t})\end{array}$ & $\mathbf{p H}$ & $\begin{array}{c}\mathbf{R}_{\text {massa }} \\
(\%)\end{array}$ & $\begin{array}{c}\mathbf{R A l}_{2} \mathbf{O}_{3 \text { aprov }} \\
(\%)\end{array}$ & $\begin{array}{c}\mathbf{A l}_{2} \mathbf{O}_{3 \text { aprov }} \\
(\%)\end{array}$ \\
\hline 6 & 306 & 0 & 10 & 41,1 & 77,4 & 22,2 \\
7 & 304 & 200 & 10 & 39,3 & 78,2 & 23,5 \\
8 & 290 & 300 & 10 & 44,8 & 82,3 & 21,8 \\
9 & 317 & 400 & 10 & 48,9 & 78,0 & 18,8 \\
10 & 307 & 600 & 10 & 54,0 & 69,8 & 15,6 \\
\hline
\end{tabular}

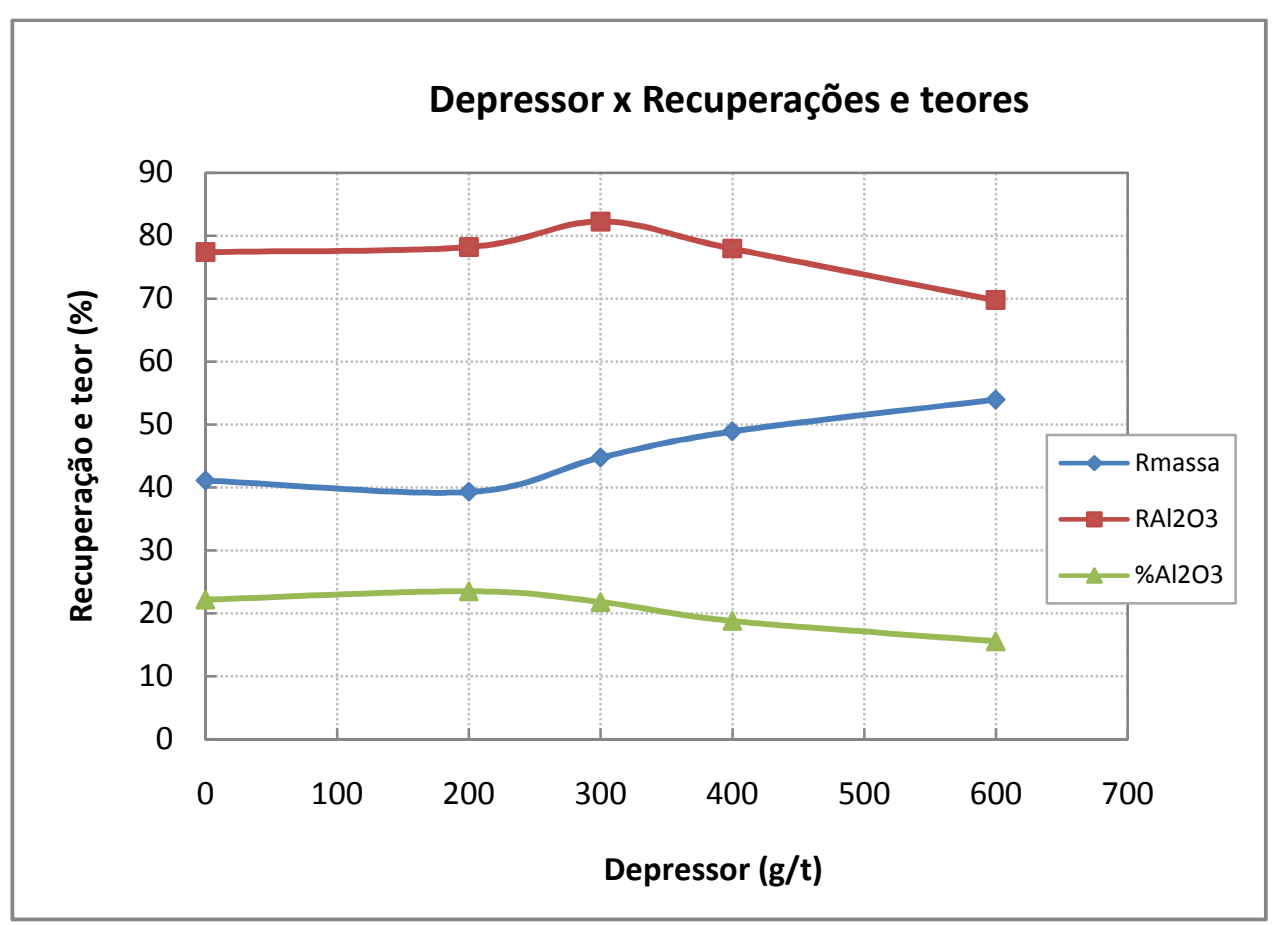

Gráfico 4 - Recuperações e teores de alumina em função da variação da concentração de depressor

Do gráfico 4 é verificado que:

- a recuperação em massa do deprimido aumenta com a dosagem de depressor; 
- a recuperação de $\mathrm{Al}_{2} \mathrm{O}_{3}$ aproveitável no deprimido é máxima na concentração de $300 \mathrm{~g} / \mathrm{t}$ de depressor, com 82,3\%. O teor de alumina aproveitável é de $21,8 \%$;

- o teor de $\mathrm{Al}_{2} \mathrm{O}_{3}$ aproveitável diminui com o aumento da dosagem, apresentando valor máximo em $200 \mathrm{~g} / \mathrm{t}$, com $23,5 \%$ de alumina. Vale salientar que, após a separação magnética, o teor aumenta para 42,6\% de alumina aproveitável, o teor de $\mathrm{SiO}_{2}$ reativa é $1,5 \%$ e de $\mathrm{Fe}_{2} \mathrm{O}_{3}$ é $12,9 \%$, portanto, dentro das especificações; e

- a dosagem ótima de depressor determinada foi de $300 \mathrm{~g} / \mathrm{t}$.

\subsection{FLOTAÇÃO COM “CLEANER" E "SCAVENGER"}

A tabela 5 apresenta os resultados das recuperações de massa e $\mathrm{Al}_{2} \mathrm{O}_{3}$ aproveitável e os teores de $\mathrm{SiO}_{2}$ (total, reativa e insolúvel), $\mathrm{Fe}_{2} \mathrm{O}_{3}$ e $\mathrm{Al}_{2} \mathrm{O}_{3}$ aproveitável para o experimento de flotação com as etapas "cleaner" e "scavenger". Lembrando que D4 é o concentrado final, que sofre separação magnética, F5 é o rejeito final, D6 é o deprimido do "rougher" II, D7 e F7 são os deprimido e flotado do "cleaner" II. Os resultados completos são apresentados no APÊNDICE C.

Tabela 5 - Recuperações e teores para os produtos da flotação com "cleaner" e "scavenger"

\begin{tabular}{|c|c|c|c|c|c|c|c|c|}
\hline Etapas & Produtos & $\begin{array}{c}\mathbf{R}_{\text {massa }} \\
(\%)\end{array}$ & $\begin{array}{l}\mathrm{SiO}_{\text {2total }} \\
\text { (\%) }\end{array}$ & $\begin{array}{c}\mathrm{SiO}_{2 \text { reat }} \\
(\%)\end{array}$ & $\begin{array}{c}\mathrm{SiO}_{\text {2insol }} \\
(\%)\end{array}$ & $\begin{array}{c}\mathrm{Fe}_{2} \mathrm{O}_{3} \\
(\%)\end{array}$ & $\begin{array}{c}\mathrm{Al}_{2} \mathrm{O}_{3 \mathrm{aprov}} \\
(\%)\end{array}$ & $\begin{array}{c}\mathrm{RAI}_{2} \mathrm{O}_{3 \text { aprov }} \\
(\%)\end{array}$ \\
\hline $1^{\mathrm{a}}$ & $\begin{array}{c}\text { D4 } \\
\text { F5 } \\
\text { Alim. }\end{array}$ & $\begin{array}{c}46,3 \\
53,7 \\
100,0\end{array}$ & $\begin{array}{c}7,8 \\
88,6 \\
51,2\end{array}$ & $\begin{array}{l}0,86 \\
0,24 \\
0,50\end{array}$ & $\begin{array}{c}7,0 \\
88,3 \\
51,0\end{array}$ & $\begin{array}{c}38,9 \\
7,8 \\
22,2\end{array}$ & $\begin{array}{c}25,6 \\
1,7 \\
12,7\end{array}$ & $\begin{array}{c}92,9 \\
7,1 \\
100,0\end{array}$ \\
\hline $2^{\underline{a}}$ & $\begin{array}{c}\text { D6 } \\
\text { D7 } \\
\text { F7 } \\
\text { Alim. }\end{array}$ & $\begin{array}{c}27,9 \\
34,9 \\
37,2 \\
100,0\end{array}$ & $\begin{array}{l}20,7 \\
50,0 \\
71,7 \\
49,9\end{array}$ & $\begin{array}{l}1,4 \\
1,3 \\
6,6 \\
3,3\end{array}$ & $\begin{array}{l}19,3 \\
48,8 \\
65,1 \\
47,0\end{array}$ & $\begin{array}{l}33,3 \\
24,2 \\
14,5 \\
23,1\end{array}$ & $\begin{array}{c}17,8 \\
4,2 \\
6,8 \\
9,0\end{array}$ & $\begin{array}{c}55,4 \\
16,5 \\
28,1 \\
100,0\end{array}$ \\
\hline $\begin{array}{c}\text { Sep. } \\
\text { Magnética }\end{array}$ & $\begin{array}{c}\mathrm{D} 4_{\mathrm{MAG}} \\
\mathrm{D} 4_{\tilde{N}-\mathrm{MAG}}\end{array}$ & $\begin{array}{l}28,5 \\
17,8\end{array}$ & $\begin{array}{c}5,4 \\
11,7\end{array}$ & $\begin{array}{l}0,92 \\
0,76\end{array}$ & $\begin{array}{c}4,5 \\
11,0\end{array}$ & $\begin{array}{l}55,8 \\
11,9\end{array}$ & $\begin{array}{l}10,8 \\
49,2\end{array}$ & $\begin{array}{l}24,1 \\
68,7\end{array}$ \\
\hline
\end{tabular}

Pela tabela 5, conclui-se que:

- o concentrado final de bauxita após a separação magnética (D4 $\left.4_{\tilde{N}-\mathrm{MAG}}\right)$ representa 17,8\% da massa de alimentação do "rougher" I; 
- os teores do concentrado final (D4 $4_{\tilde{N}-M A G}$ ) são: $0,76 \%$ de $\mathrm{SiO}_{\text {2reativa, }}$ $11,9 \%$ de $\mathrm{Fe}_{2} \mathrm{O}_{3}$ e $49,2 \%$ de $\mathrm{Al}_{2} \mathrm{O}_{3}$, com recuperação de alumina aproveitável de $68,7 \%$, portanto, dentro das especificações. A recuperação em massa é de $17,8 \%$;

- o concentrado magnético (D4 ${ }_{\mathrm{MAG}}$ ) possui recuperação de massa de $28,5 \%$ e o teor de $\mathrm{Fe}_{2} \mathrm{O}_{3}$ é de $55,8 \%$;

- o deprimido do segundo "rougher" (D6) não tinha massa suficiente para a etapa "scavenger" II; e

- o "cleaner" II gerou produtos (D7 e F7) com baixo teor de alumina aproveitável, $4,2 \%$ e $6,8 \%$, respectivamente, mas o teor de $\mathrm{SiO}_{2}$ reativa do flotado F7 é superior, com 6,6\%.

\subsection{PREPARAÇÃO DAS AMOSTRAS}

O ensaio de flotação sem a deslamagem do minério resultou nos valores que estão na tabela 6 :

Tabela 6 - Resultados da flotação sem deslamagem

\begin{tabular}{c|c|c|c|c|c|c|c}
\hline Amostra & $\begin{array}{c}\mathbf{R}_{\text {massa }} \\
(\%)\end{array}$ & $\begin{array}{c}\mathbf{S i O}_{\text {2total }} \\
(\%)\end{array}$ & $\begin{array}{c}\mathrm{SiO}_{\text {2reativa }} \\
(\%)\end{array}$ & $\begin{array}{c}\mathrm{SiO}_{\text {2insolúvel }} \\
(\%)\end{array}$ & $\begin{array}{c}\mathrm{Fe}_{2} \mathbf{O}_{3} \\
(\%)\end{array}$ & $\begin{array}{c}\mathrm{Al}_{2} \mathbf{O}_{3 \text { aprov }} \\
(\%)\end{array}$ & $\begin{array}{c}\mathbf{R A I}_{2} \mathbf{O}_{3 \text { aprov }} \\
(\%)\end{array}$ \\
\hline Alimentação1 & 100,0 & 46,6 & 5,2 & 41,4 & 18,4 & 13,1 & 100,0 \\
Flotado1 & 67,8 & 64,6 & 5,8 & 58,8 & 12,6 & 6,8 & 35,3 \\
Deprimido1 & 32,1 & 8,5 & 3,7 & 4,7 & 30,6 & 26,3 & 64,7 \\
\hline Alimentação2 & 100,0 & 49,1 & 4,2 & 44,9 & 17,9 & 13,5 & 100,0 \\
Flotado2 & 68,7 & 67,2 & 4,7 & 62,5 & 11,6 & 7,6 & 38,9 \\
Deprimido2 & 31,3 & 9,2 & 3,0 & 6,3 & 31,8 & 26,3 & 61,0 \\
\hline
\end{tabular}

Observando a tabela 6, nota-se que:

- a quantidade de sílica reativa é muito alta em todas as amostras; e

- a recuperação de alumina aproveitável é inferior aos outros resultados obtidos. 
Estes fatores mostram a necessidade da deslamagem do minério antes da flotação. Os fluxogramas deste experimento encontram-se no APÊNDICE D.

A fração abaixo de $10 \mu \mathrm{m}$ (lama) representava, aproximadamente, 1\% da massa da amostra, após a retirada do material acima de $210 \mu \mathrm{m}$.

\subsection{CARACTERIZAÇÃO DAS AMOSTRAS}

A análise química por faixa granulométrica (malhas 0,42, 0,21, 0,149, 0,104 e $0,037 \mathrm{~mm}$ ) do rejeito (UF do ciclone de 6") da primeira amostragem (amostra 1) é apresentada no trabalho de Freitas (2004) e reproduzida na tabela 7 para podermos comparar com os resultados da análise química da amostra 2 (segunda amostragem).

Tabela 7 - Análise química da amostra 1 por faixa granulométrica

\begin{tabular}{c|c|c|c|c|c|c}
\hline $\begin{array}{c}\text { Fração } \\
(\mathbf{m m})\end{array}$ & $\begin{array}{c}\mathrm{SiO}_{2 \text { Total }} \\
(\%)\end{array}$ & $\begin{array}{c}\mathrm{SiO}_{2 \text { reativa }} \\
(\%)\end{array}$ & $\begin{array}{c}\mathrm{SiO}_{\text {2insolúvel }} \\
(\%)\end{array}$ & $\begin{array}{c}\mathrm{Fe}_{2} \mathrm{O}_{3} \\
(\%)\end{array}$ & $\begin{array}{c}\mathrm{TiO}_{2} \\
(\%)\end{array}$ & $\begin{array}{c}\mathrm{Al}_{2} \mathbf{O}_{3 a p r o v} \\
(\%)\end{array}$ \\
\hline$+0,42$ & 26,00 & 1,50 & 24,50 & 24,27 & 0,72 & 24,62 \\
$-0,42+0,21$ & 44,80 & 1,30 & 43,50 & 19,00 & 1,00 & 16,98 \\
$-0,21+0,149$ & 59,70 & 0,60 & 59,10 & 14,37 & 1,45 & 12,31 \\
$-0,149+0,104$ & 59,00 & 1,00 & 58,00 & 15,33 & 4,00 & 11,04 \\
$-0,104+0,037$ & 36,20 & 2,30 & 33,90 & 27,15 & 9,09 & 11,89 \\
$-0,037$ & 11,40 & 7,10 & 4,30 & 30,34 & 5,09 & 16,98 \\
\hline
\end{tabular}

A tabela 8 mostra a análise química da amostra de cabeça (AQC) e por faixa granulométrica do rejeito da segunda amostragem (amostra 2), nas malhas 0,42, $0,21,0,149,0,104,0,074$ e $0,037 \mathrm{~mm}$. Também aparecem as massas retidas nos intervalos das malhas. 
Tabela 8 - Análise química por faixa granulométrica e da amostra de cabeça (AQC) da amostra 2

\begin{tabular}{c|c|c|c|c|c|c|c}
\hline $\begin{array}{c}\mathbf{F r a c ̧ a ̃ o} \\
(\mathbf{m m})\end{array}$ & $\begin{array}{c}\text { Massa } \\
(\mathbf{g})\end{array}$ & $\begin{array}{c}\text { Massa } \\
(\%)\end{array}$ & $\begin{array}{c}\mathrm{SiO}_{2 \text { total }} \\
(\%)\end{array}$ & $\begin{array}{c}\mathrm{SiO}_{2 \text { reat }} \\
(\%)\end{array}$ & $\begin{array}{c}\mathrm{SiO}_{2 \text { insol }} \\
(\%)\end{array}$ & $\begin{array}{c}\mathrm{Fe}_{2} \mathbf{O}_{3} \\
(\%)\end{array}$ & $\begin{array}{c}\mathbf{A l}_{2} \mathbf{O}_{3 a p r} \\
(\%)\end{array}$ \\
\hline$+0,42$ & 31,6 & 4,0 & 27,0 & 7,0 & 20,0 & 14,8 & 30,6 \\
$-0,42+0,21$ & 236,2 & 29,6 & 66,0 & 2,6 & 63,5 & 11,8 & 11,9 \\
$-0,21+0,149$ & 165,2 & 20,7 & 63,4 & 3,9 & 59,5 & 12,4 & 11,0 \\
$-0,149+0,104$ & 144,1 & 18,1 & 54,2 & 3,5 & 50,7 & 15,9 & 12,7 \\
$-0,104+0,074$ & 82,1 & 10,3 & 42,2 & 4,6 & 37,6 & 21,3 & 17,8 \\
$-0,074+0,037$ & 93,7 & 11,8 & 25,9 & 7,0 & 18,9 & 24,9 & 17,8 \\
$-0,037$ & 44,0 & 5,5 & 18,2 & 3,5 & 14,7 & 25,8 & 16,1 \\
\hline TOTAL & 796,9 & 100,0 & 52,0 & 4,0 & 48,0 & 16,1 & 14,1 \\
\hline AQC & & & 52,9 & 5,1 & 47,8 & 16,8 & 13,2 \\
\hline
\end{tabular}

A tabela 9 e gráfico 5 apresentam os resultados da análise granulométrica a úmido da amostra 2, nas malhas 0,42, 0,21, 0,149, 0,104, 0,074 e 0,037 mm.

\begin{tabular}{c|c|c}
\multicolumn{3}{|c}{ Tabela 9 - Análise granulométrica da amostra } \\
\hline $\begin{array}{c}\text { Abertura } \\
(\mathbf{m m})\end{array}$ & $\begin{array}{c}\text { Passante } \\
(\mathbf{g})\end{array}$ & $\begin{array}{c}\text { Passante } \\
\text { (\%) }\end{array}$ \\
\hline 0,42 & 765,2 & 96,0 \\
0,21 & 529,0 & 66,4 \\
0,149 & 363,8 & 45,7 \\
0,104 & 219,7 & 27,6 \\
0,074 & 137,7 & 17,3 \\
0,037 & 44,0 & 5,5 \\
\hline Total & 796,9 & 100,0 \\
\hline
\end{tabular}




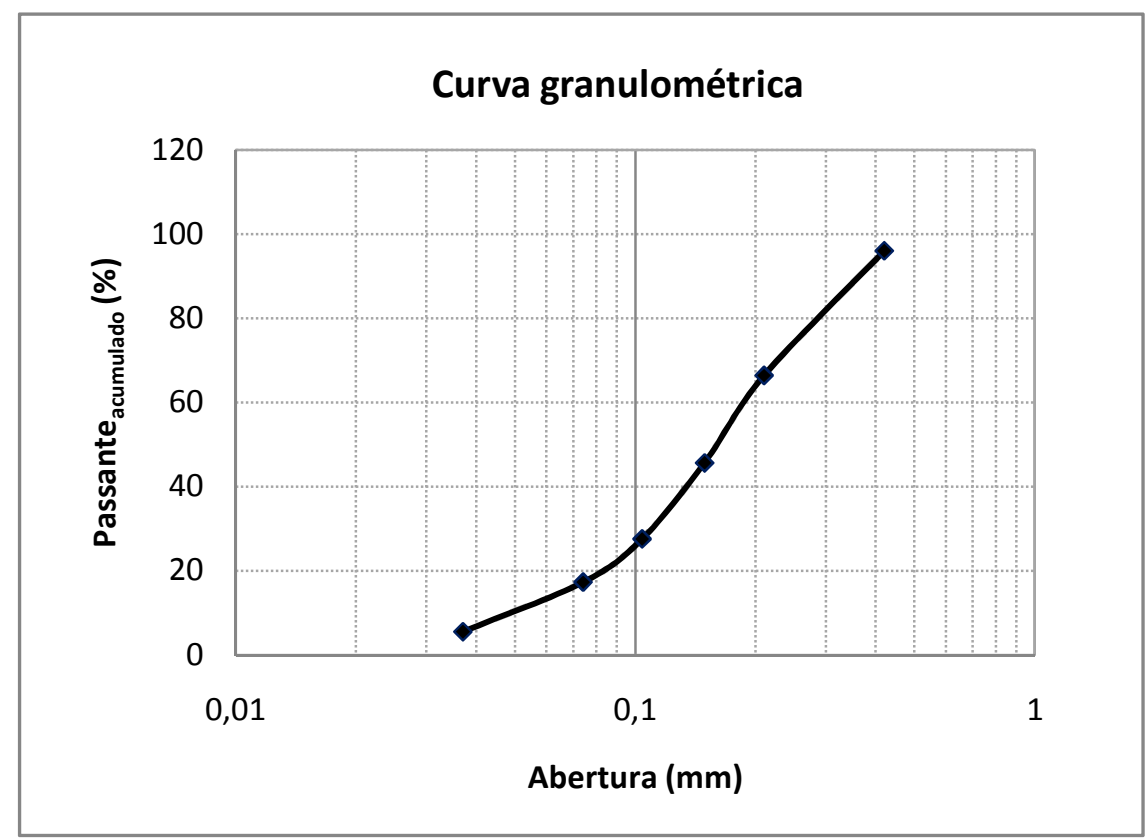

Gráfico 5 - Curva granulométrica da amostra de cabeça do rejeito

Pelas tabelas 8 e 9 , e pelo gráfico 5 , observa-se:

- a fração passante na malha $0,21 \mathrm{~mm}$ e retida em $0,15 \mathrm{~mm}$ representa $20,7 \%$ da massa total da amostra 2, onde os teores de $\mathrm{SiO}_{2}$ total, reativa e insolúvel são superiores para esta amostra do rejeito em $3,7 \%, 3,3 \%$ e $0,4 \%$, respectivamente, em comparação com a amostra 1

- a fração passante em $0,15 \mathrm{~mm}$ e retida em $0,104 \mathrm{~mm}$ representa $18 \%$ da massa total da amostra 2 e os teores de $\mathrm{SiO}_{2}$ reativa, $\mathrm{Fe}_{2} \mathrm{O}_{3}$ e $\mathrm{Al}_{2} \mathrm{O}_{3}$ aproveitável são maiores em 2,5\%, 0,6\% e 1,7\%, respectivamente, em comparação com a amostra 1;

- a fração passante em 0,104 mm e retida em 0,037 mm corresponde a $22 \%$ da massa total da amostra 2 . Até a malha $0,074 \mathrm{~mm}$, o teor de $\mathrm{SiO}_{2}$ total é de $42,2 \%$ e da malha $0,074 \mathrm{~mm}$ até a $0,037 \mathrm{~mm}$ é de $25,9 \%$. Para a amostra 10 teor de $\mathrm{SiO}_{2}$ total é de $36,2 \%$ entre as malhas $0,104 \mathrm{~mm}$ e $0,037 \mathrm{~mm}$;

- a fração passante na malha $0,037 \mathrm{~mm}$ corresponde a 5,5\% da massa total da amostra 2, sendo que os teores de $\mathrm{SiO}_{2}$ total e insolúvel são superiores em 6,8\% e 10,4\%, em relação à amostra 1 ;

Como no trabalho de Freitas (2004) não é apresentada a análise granulométrica da amostra utilizada, não foi possível compará-la com esta nova 
amostra. Segundo consta no seu trabalho, o teor de $\mathrm{SiO}_{2}$ total do UF do ciclone de 6 " é de $44,5 \%$. Já para a amostra 2, segundo a análise química da amostra de cabeça, o teor de $\mathrm{SiO}_{2}$ total é de $52,9 \%$, portanto $8,4 \%$ superior.

Posteriormente, foi feita uma análise por difratometria de raios $X$ e uma análise química semiquantitativa por espectrometria de fluorescência de raios $X$, cujos resultados são mostrados, respectivamente, nas tabelas 10 e 11. Os ANEXOS A e B apresentam os resultados completos.

\begin{tabular}{|c|c|}
\hline Mineral & Fórmula química \\
\hline Quartzo & $\mathrm{SiO}_{2}$ \\
\hline Cristobalita & $\mathrm{SiO}_{2}$ \\
\hline Gibbsita & $\mathrm{Al}(\mathrm{OH})_{3}$ \\
\hline Ilmenita & $\mathrm{FeTiO}_{3}$ \\
\hline Caulinita & $\mathrm{Al}_{2}\left(\mathrm{Si}_{2} \mathrm{O}_{5}\right)(\mathrm{OH})_{4}$ \\
\hline
\end{tabular}

Tabela 11 - Resultado da análise química semiquantitativa por espectrometria de fluorescência de

\begin{tabular}{c|c}
\multicolumn{2}{c}{ raios X (\%) } \\
\hline Amostra & UF do ciclone de 6" \\
\hline $\mathrm{Al}_{2} \mathrm{O}_{3}$ & 19,7 \\
$\mathrm{SiO}_{2}$ & 47,8 \\
$\mathrm{P}_{2} \mathrm{O}_{5}$ & 0,22 \\
$\mathrm{SO}_{3}$ & 0,14 \\
$\mathrm{~K}_{2} \mathrm{O}$ & 0,02 \\
$\mathrm{CaO}$ & 0,02 \\
$\mathrm{TiO}_{2}$ & 4,43 \\
$\mathrm{~V}_{2} \mathrm{O}_{5}$ & 0,03 \\
$\mathrm{Cr}_{2} \mathrm{O}_{3}$ & 0,09 \\
$\mathrm{MnO}$ & 0,03 \\
$\mathrm{Fe}_{2} \mathrm{O}_{3}$ & 17,3 \\
$\mathrm{ZnO}$ & 0,01 \\
$\mathrm{ZrO}_{2}$ & 0,26 \\
$\mathrm{Nb}_{2} \mathrm{O}_{5}$ & 0,01 \\
$\mathrm{PF}$ & 10,0 \\
\hline
\end{tabular}




\subsubsection{Microscopia eletrônica de varredura}

Uma das amostras do rejeito coletada durante a campanha de amostragem em julho de 2005 foi analisada ao microscópio eletrônico de varredura. A amostra, preparada em seção polida refere-se ao "underflow" (UF) do ciclone de 6". É importante citar que minerais com elementos químicos de menor massa atômica aparecem mais escuros nas imagens e os de maior massa, mais claros. Elementos de massa atômica inferior a 6 ( $B, B e$ e $L i$, por exemplo) não são detectados pelo analisador de raios $\mathrm{X}$.

A figura 19 mostra uma vista geral do rejeito, com grãos de gibsita $\left(\mathrm{Al}(\mathrm{OH})_{3}\right)$ bem liberados. Como contaminantes, há grãos livres de quartzo, cristobalita e ilmenita.

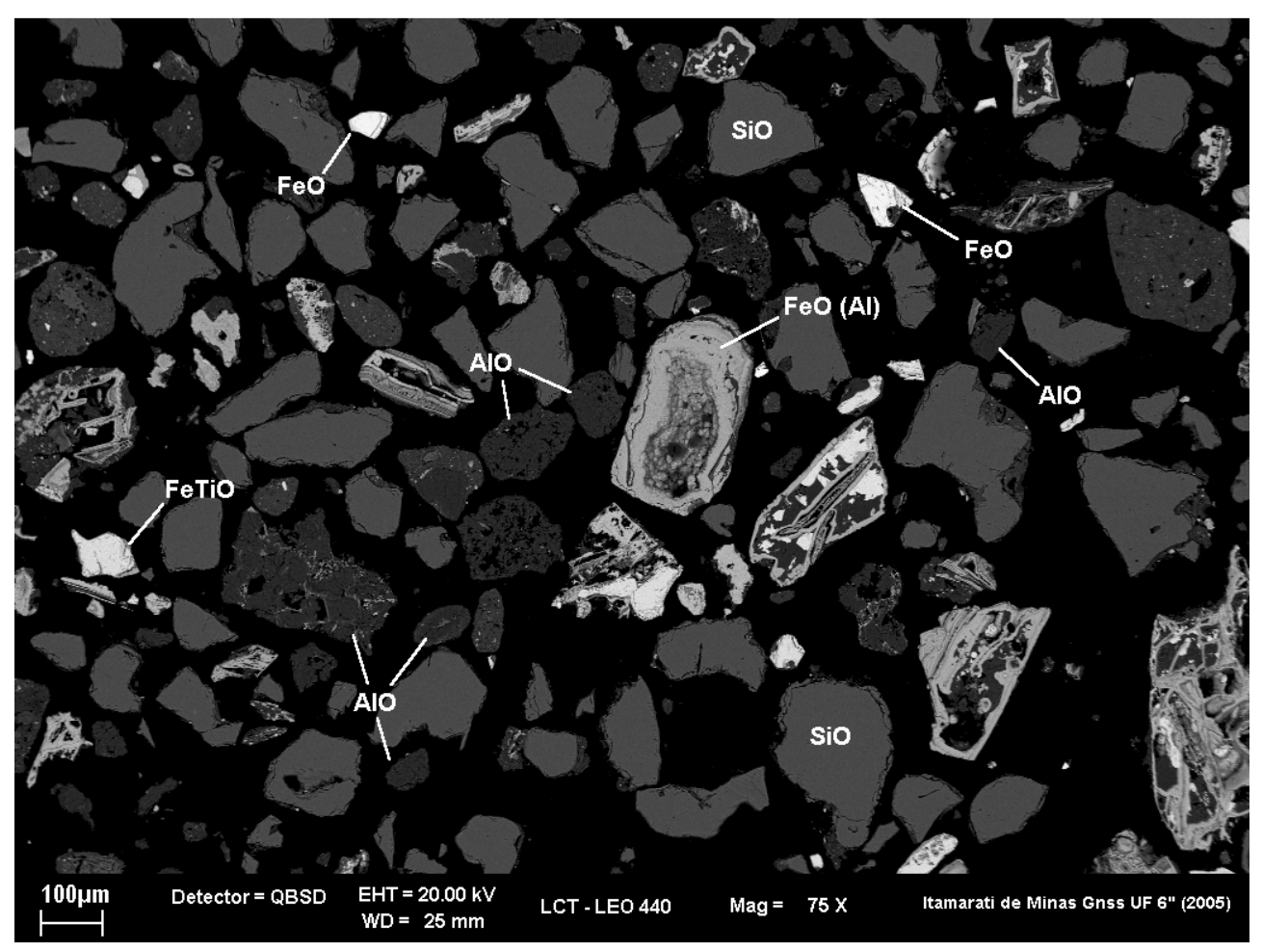

Figura 19 - Aspecto geral do UF do ciclone de 6"

Um detalhe dos grãos é mostrado na figura 20: grãos de quartzo liberados, grãos mistos de gibsita com ilmenita e de gibsita com um provável silicato de alumínio com óxido de ferro. A figura 21 mostra um detalhe de outro grão misto, de gibsita com um silicato (FeAIO(SiPS)). Também aparece um grão de ilmenita. Outro 
detalhe está na figura 22, que mostra um grão com óxido de alumínio com silicato de ferro, titânio e enxofre (AIO(SiFeTiS)) e um grão misto de gibsita com quartzo. A figura 23 mostra grãos de gibsita com contaminações de silicatos (FeAIO(SiSP), $\mathrm{FeO}(\mathrm{AlSi})$ ) e óxido de ferro. É possível observar outro grão de ilmenita e grãos de quartzo liberados. Outra vista geral é mostrada na figura 24. Observando todas essas imagens, conclui-se: os grãos de gibsita são arredondados e os de quartzo, angulosos; a amostra está bem liberada para a flotação, apesar da presença de grãos contaminados que podem influir negativamente sobre o teor do concentrado.

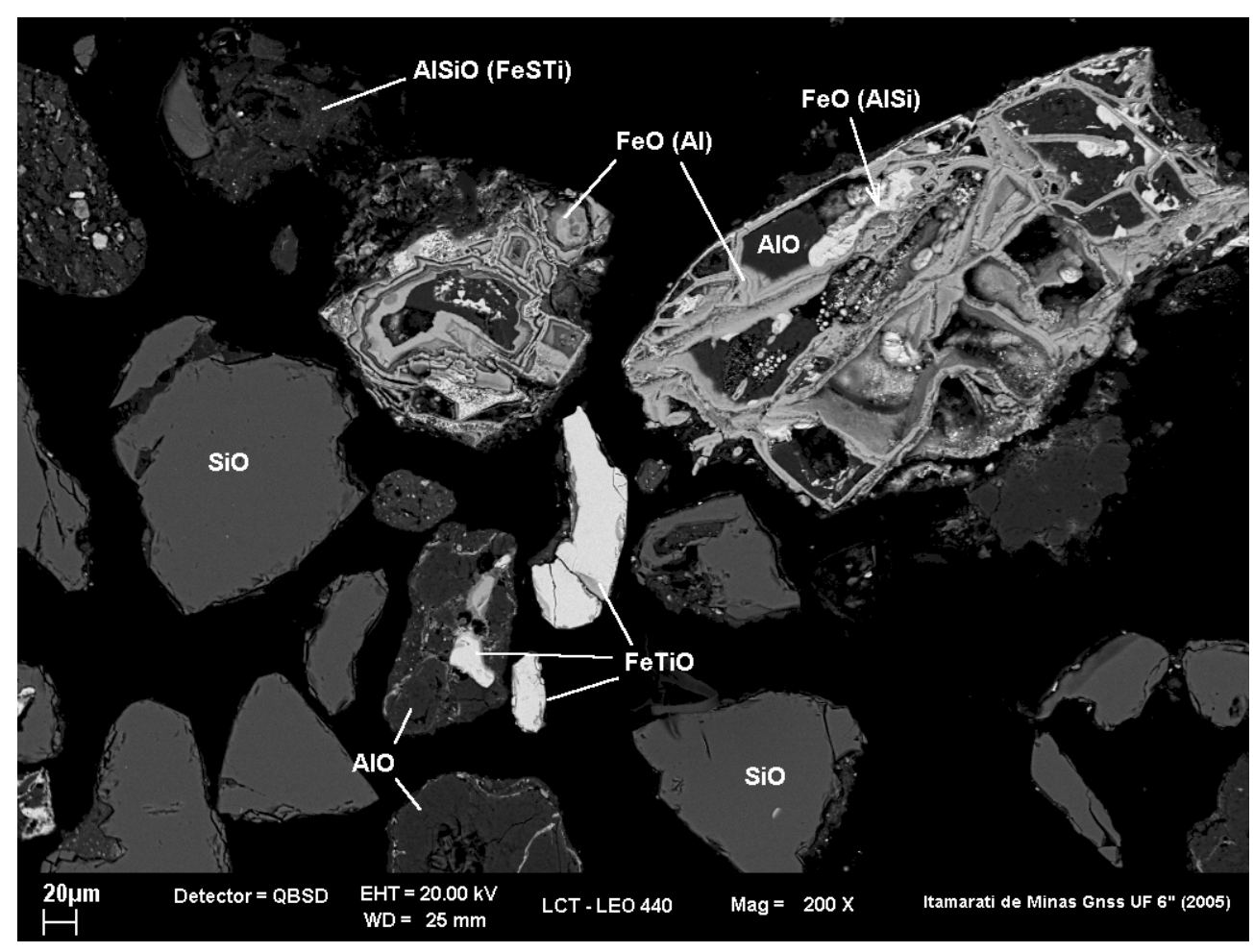

Figura 20 - Detalhe dos grãos do UF do ciclone de 6" 


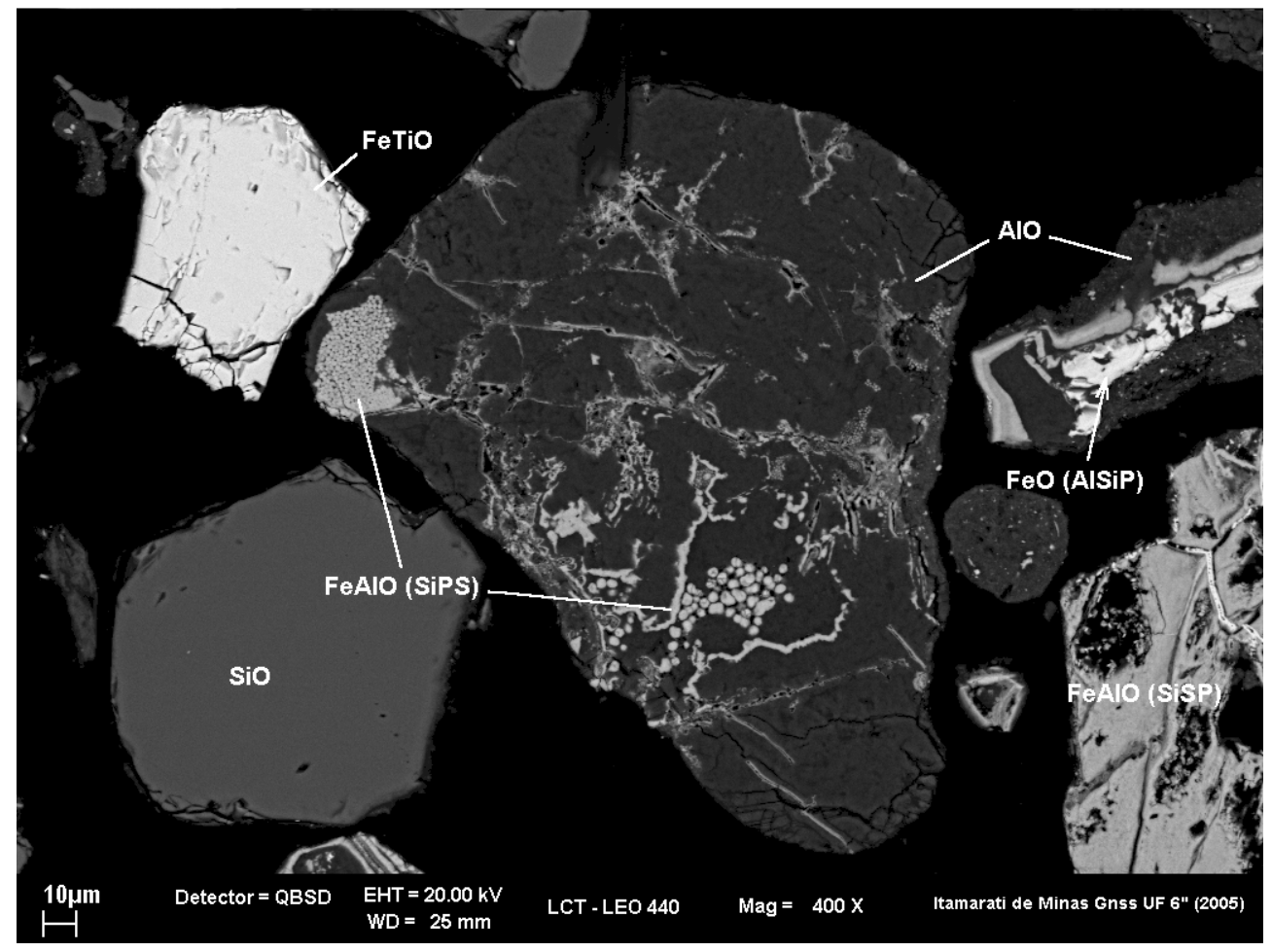

Figura 21 - Detalhe de grão misto do UF do ciclone de 6"

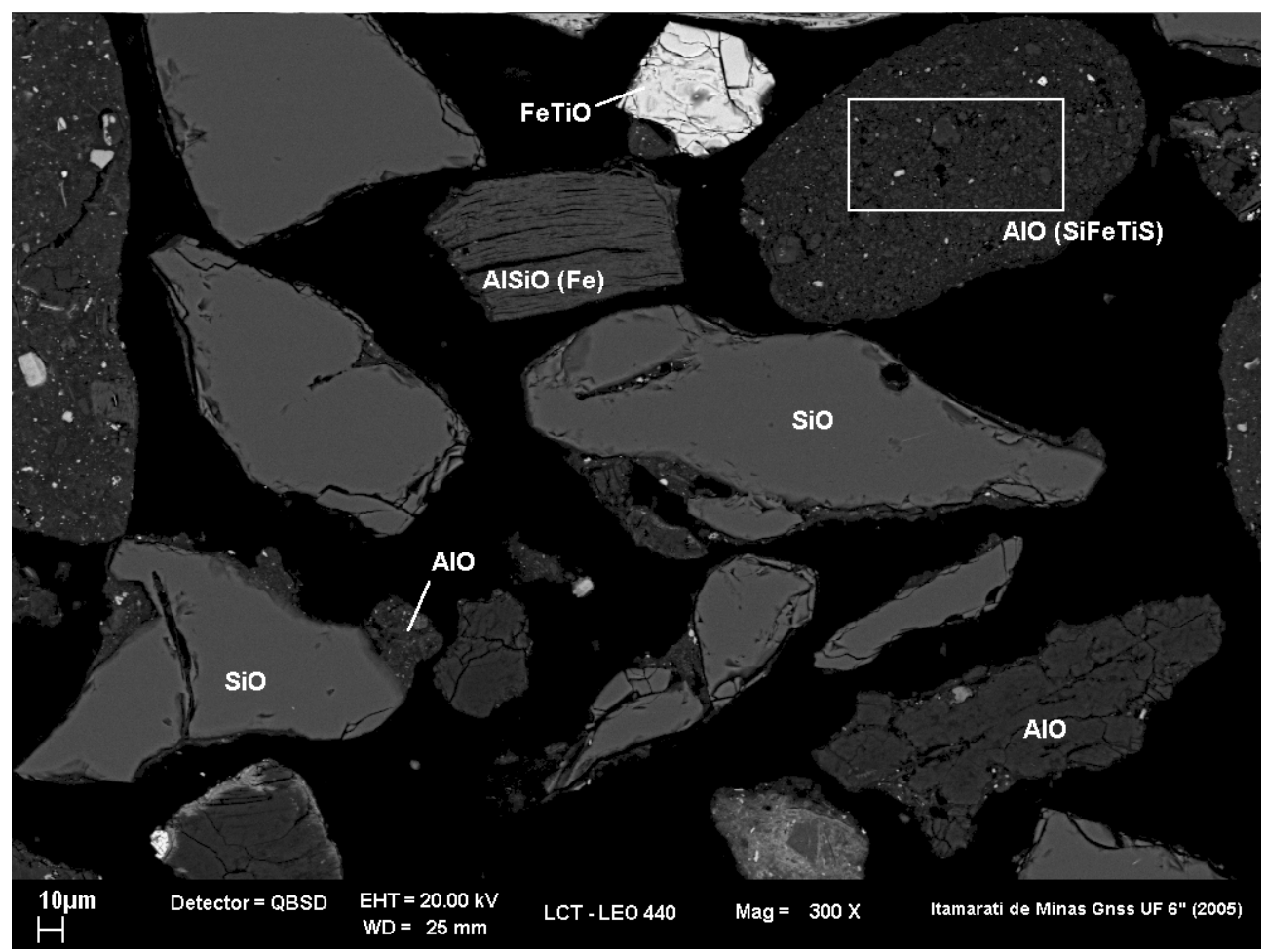

Figura 22 - Outro detalhe de grão misto do UF do ciclone de 6" 


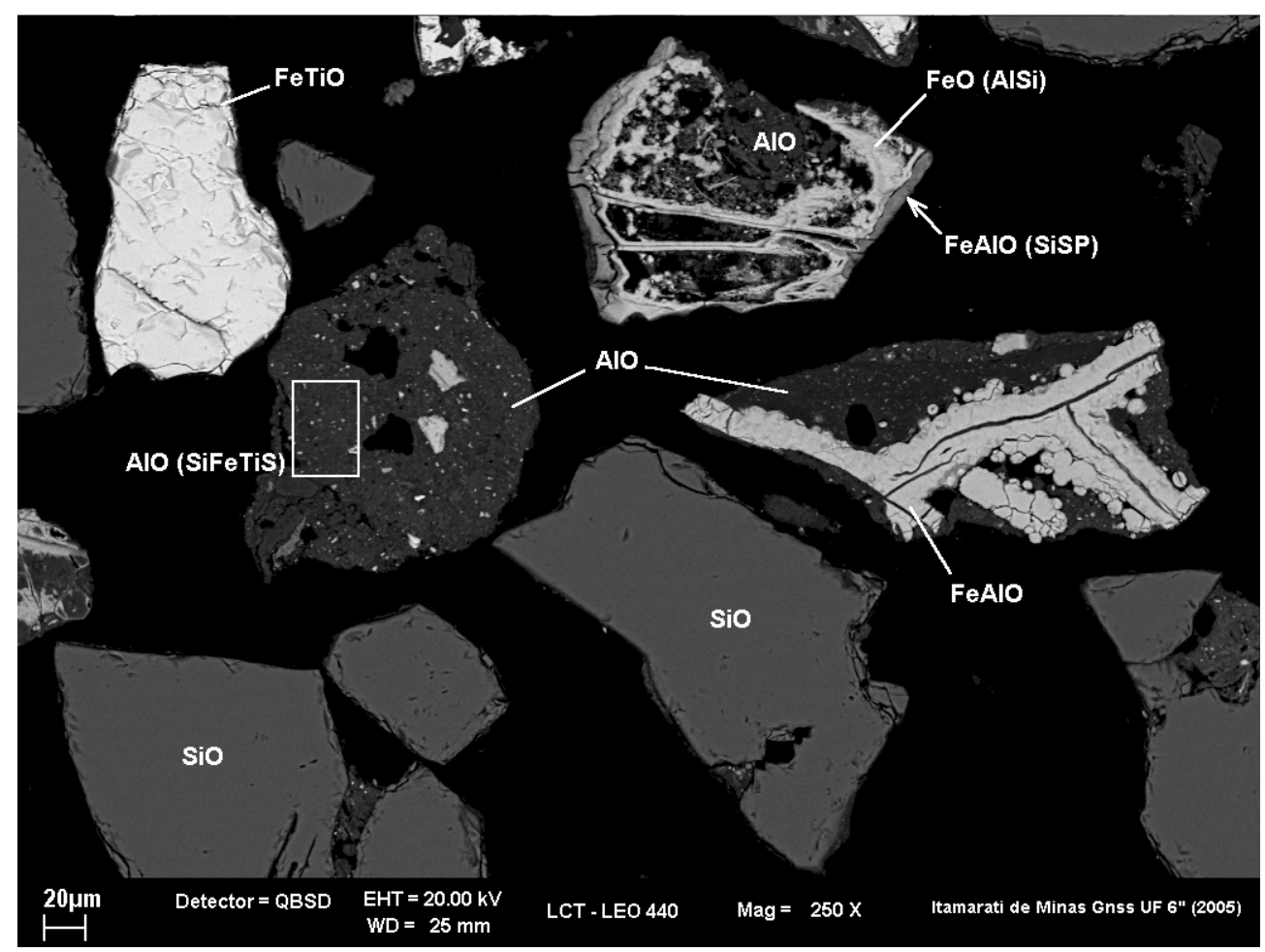

Figura 23 - Grãos de gibsita contaminados no UF do ciclone de 6"

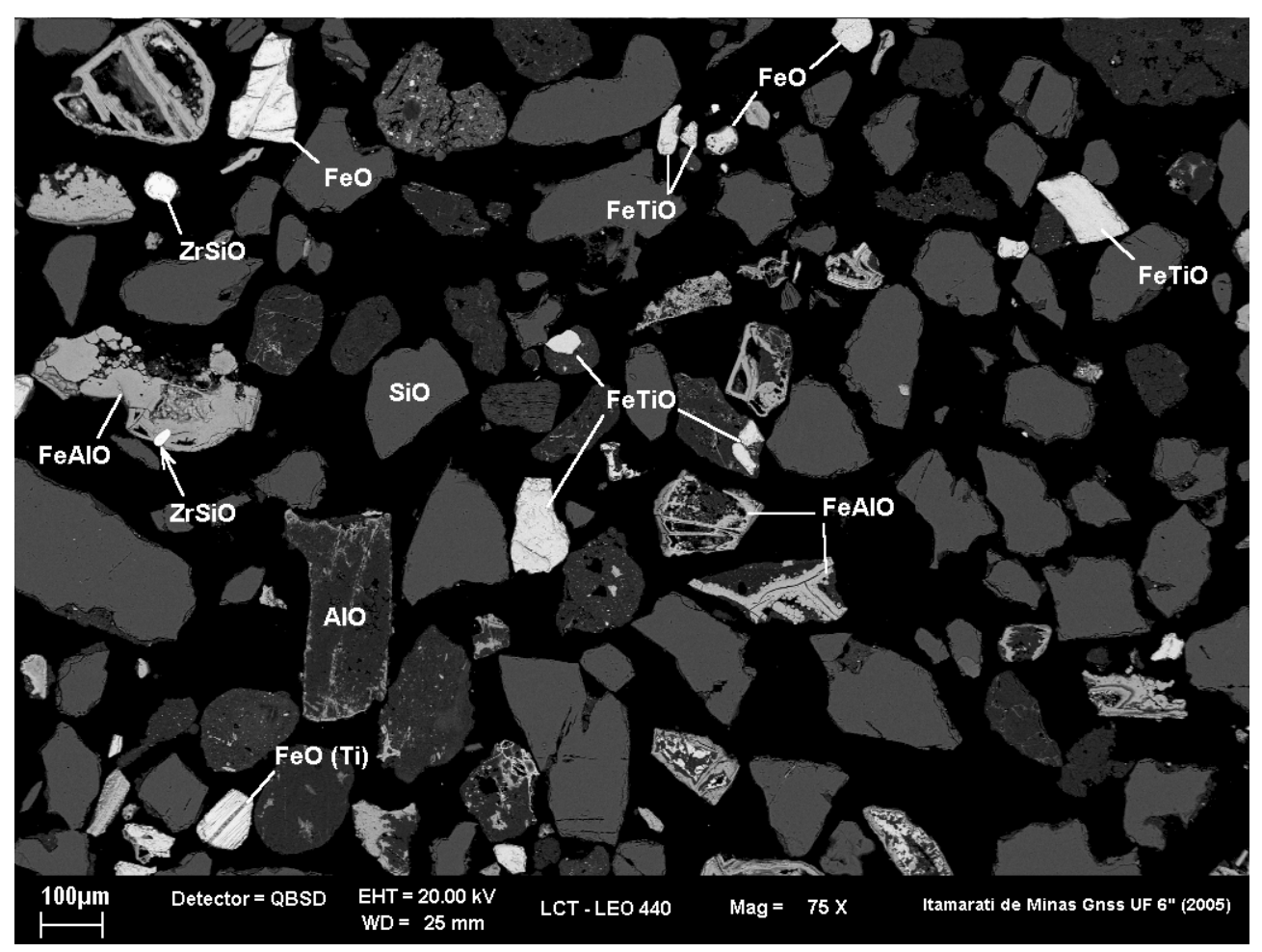

Figura 24 - Vista geral da amostra do UF do ciclone de 6" 


\subsection{FLOTAÇÃO COM RECIRCULAÇÃO DE PRODUTOS}

A tabela 12 apresenta as recuperações de massa e $\mathrm{Al}_{2} \mathrm{O}_{3}$ aproveitável e os teores de $\mathrm{SiO}_{2}$ (total, reativa e insolúvel), $\mathrm{Fe}_{2} \mathrm{O}_{3}$ e $\mathrm{Al}_{2} \mathrm{O}_{3}$ aproveitável para 0 experimento de flotação com recirculação de produtos. O rejeito (flotado) é composto por todos os flotados das etapas "cleaner" e o concentrado final (deprimido) são os deprimidos das etapas "scavenger". É importante lembrar que uma alíquota do concentrado final foi submetida à separação magnética de média intensidade com imã de terras raras, resultando no produto final (concentrado de bauxita) não-magnético e no concentrado de ferro e titânio (aditivo de cimento).

Tabela 12 - Recuperações e teores para os produtos da flotação com recirculação de produtos

\begin{tabular}{c|c|c|c|c|c|c|c}
\hline Produto & $\begin{array}{c}\mathbf{R}_{\text {massa }} \\
(\%)\end{array}$ & $\begin{array}{c}\mathrm{SiO}_{2 \text { total }} \\
(\%)\end{array}$ & $\begin{array}{c}\mathrm{SiO}_{2 \text { reat }} \\
(\%)\end{array}$ & $\begin{array}{c}\mathrm{SiO}_{2 \text { insol }} \\
(\%)\end{array}$ & $\begin{array}{c}\mathrm{Fe}_{2} \mathrm{O}_{3} \\
(\%)\end{array}$ & $\begin{array}{c}\mathbf{A l}_{2} \mathrm{O}_{3 \text { apr }} \\
(\%)\end{array}$ & $\begin{array}{c}\mathrm{RAI}_{2} \mathrm{O}_{3 \text { apr }} \\
(\%)\end{array}$ \\
\hline Alimentação & 100,0 & 57,5 & 1,3 & 56,2 & 14,1 & 11,6 & 100,0 \\
\hline Flotado & 65,7 & 85,2 & 1,4 & 83,8 & 7,3 & 5,1 & 28,8 \\
\hline Deprimido & 27,8 & 5,5 & 1,4 & 4,1 & 33,5 & 29,7 & 71,2 \\
\hline Dep $_{\text {MAG }}$ & 14,5 & 5,2 & 1,1 & 4,1 & 57,8 & 10,2 & 12,7 \\
\hline Dep $_{\text {N-MAG }}$ & $\mathbf{1 3 , 3}$ & $\mathbf{4 , 7}$ & $\mathbf{1 , 9}$ & $\mathbf{2 , 8}$ & $\mathbf{9 , 0}$ & $\mathbf{5 2 , 6}$ & $\mathbf{6 0 , 4}$ \\
\hline
\end{tabular}

De acordo com a tabela verifica-se que:

- a recuperação em massa do deprimido é de $27,8 \%$, inferior à do experimento de flotação anterior com uma etapa "cleaner" e "scavenger", que foi de $46,3 \%$;

- em relação à separação magnética do deprimido, neste ensaio, $47,8 \%$ era não-magnético e no teste anterior $38,4 \%$;

- a recuperação de $\mathrm{Al}_{2} \mathrm{O}_{3}$ aproveitável no deprimido não-magnético é de $60,4 \%$, menor do que $68,7 \%$ do outro ensaio. Isto devido à menor recuperação em massa deste último; $\mathrm{e}$

- os teores de $\mathrm{Al}_{2} \mathrm{O}_{3}$ aproveitável, $\mathrm{SiO}_{2}$ reativa e $\mathrm{Fe}_{2} \mathrm{O}_{3}$ são, respectivamente, $52,6 \%, 1,9 \%$ e $9,0 \%$. Portanto, dentro das especificações de bauxita para fabricação de alumina $\left(\mathrm{Al}_{2} \mathrm{O}_{3}\right.$ 
aproveitável $>40 \%, \mathrm{SiO}_{2}$ reativa $<4 \%$ e $\mathrm{Fe}_{2} \mathrm{O}_{3}<18 \%$ ). $\mathrm{O}$ teor de $\mathrm{Al}_{2} \mathrm{O}_{3}$ aproveitável foi o máximo obtido em todos os experimentos.

O APÊNDICE E mostra o fluxograma com os resultados completos.

A figura 25 mostra os produtos flotado e deprimido, antes da separação magnética.

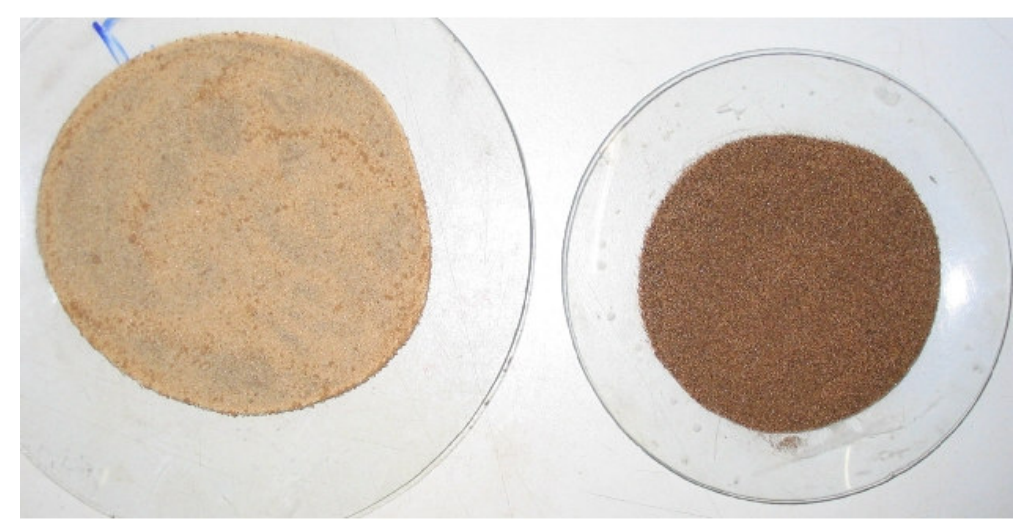

Figura 25 - Flotado e deprimido antes da separação magnética

Os produtos finais do último experimento de flotação com recirculação de produtos foram fotografados em lupa com um aumento de 6,3 vezes. Foram eles: flotado (rejeito), deprimido magnético (concentrado de ferro e titânio) e nãomagnético (concentrado final). A figura 26 mostra os três produtos respectivamente.
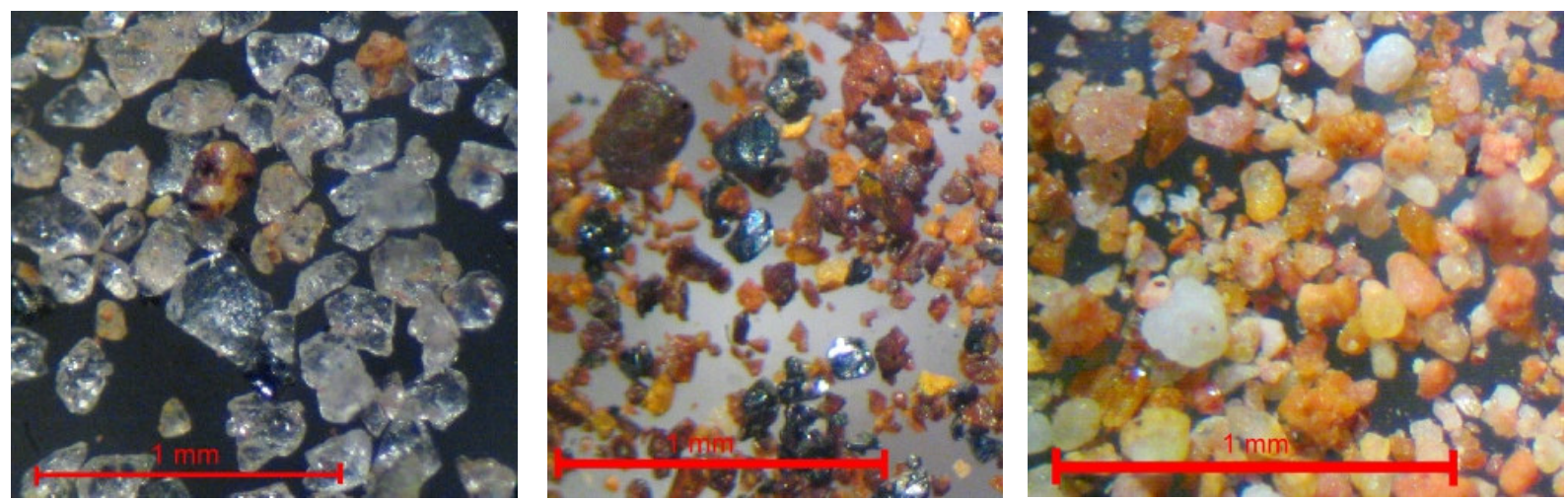

Figura 26 - Produtos finais da flotação reversa: flotado, deprimido magnético e não-magnético

Pela figura 26 observa-se a diferença visual entre os três produtos. O flotado é basicamente composto por quartzo (grãos transparentes). O deprimido magnético é composto por minerais de ferro e titânio (minerais mais escuros), com algumas partículas de gibsita. O deprimido não-magnético é formado pela bauxita, de 
aparência mais terrosa e algumas contaminações. Portanto, a concentração por flotação foi seletiva.

\subsection{SEPARAÇÃO MAGNÉTICA}

A figura 27 mostra o deprimido antes da separação magnética e os dois produtos resultantes, magnético e não-magnético.

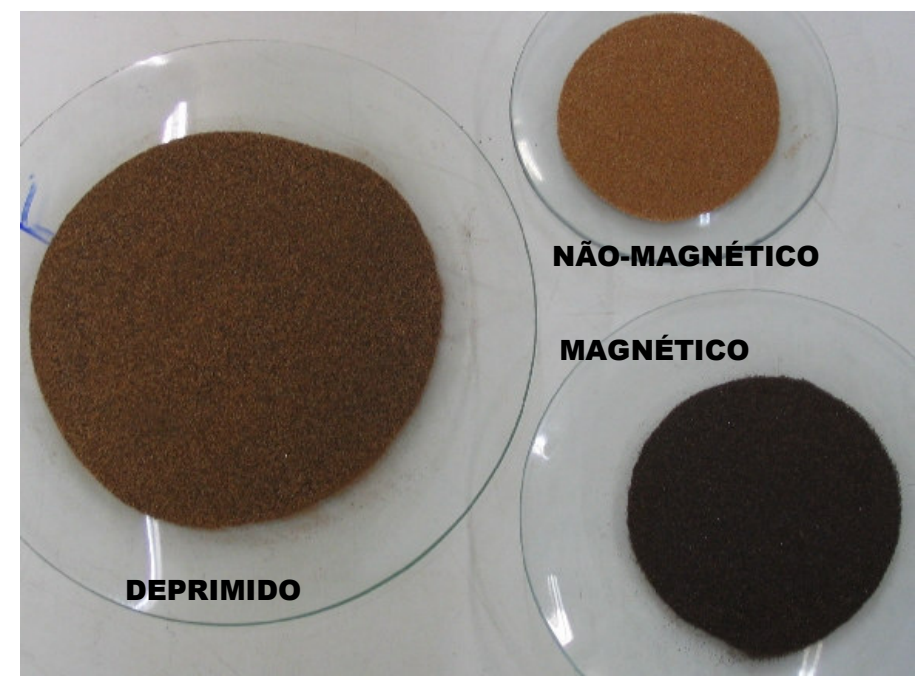

Figura 27 - Concentrado da flotação antes e após a separação magnética

Pela figura 27 observa-se a diferença visual entre os deprimidos magnéticos, que estão em maior quantidade (52\% da massa do deprimido) e os não-magnéticos, $48 \%$ da massa. Com a separação magnética, o teor do deprimido que era de $29,7 \%$ de alumina aproveitável, aumenta para $52,6 \%$ no deprimido não-magnético. Estes valores justificam a separação. Deve-se informar que o separador magnético de alta intensidade via úmida (HIWMS) já existe na usina de Itamarati de Minas e tem reserva de capacidade suficiente para absorver esta ampliação. 


\section{DISCUSSÃO DOS RESULTADOS}

Os resultados foram analisados considerando as especificações da bauxita para fabricação de alumina, segundo a CBA: granulometria abaixo de $50 \mathrm{~mm}$ (2"); teor de $\mathrm{Al}_{2} \mathrm{O}_{3}$ aproveitável acima de $40 \%$; teor de $\mathrm{SiO}_{2}$ reativa abaixo de $4 \%$; e teor de $\mathrm{Fe}_{2} \mathrm{O}_{3}$ abaixo de $18 \%$.

Com a amostra 1 (amostragem de 2004) foram realizados ensaios sistemáticos para a determinação das dosagens de reagentes que resultariam nos maiores teores de alumina aproveitável, combinados às maiores recuperações de massa e de alumina do concentrado da flotação. Para o coletor, Flotigam EDA, a dosagem otimizada foi de $300 \mathrm{~g} / \mathrm{t}$, onde o teor de $\mathrm{Al}_{2} \mathrm{O}_{3}$ aproveitável foi o máximo $(24,6 \%)$ e as recuperações de massa $(30,6 \%)$ e de alumina $(72,9 \%)$ foram boas. Para o depressor, solução de amido de milho a $2 \%$, a dosagem otimizada também foi de $300 \mathrm{~g} / \mathrm{t}$, ponto onde a recuperação de $\mathrm{Al}_{2} \mathrm{O}_{3}$ aproveitável foi máxima $(82,3 \%)$, com teor relativamente alto $(21,8 \%)$ e boa recuperação em massa $(44,8 \%)$.

Os ensaios de flotação com as etapas "cleaner" e "scavenger", realizados com a amostra 1 ainda, serviram para verificar o comportamento do processo e definir um balanço de massas, utilizando as dosagens otimizadas de coletor e depressor definidas anteriormente. Como a flotação é reversa, convencionou-se chamar de "cleaner" a flotação do flotado e de "scavenger" a flotação do deprimido. O experimento completou um ciclo de flotações "rougher", "cleaner" e "scavenger", e um segundo ciclo de "rougher" e "cleaner", conforme mostra o item 3.3. Foram obtidos: um concentrado final (deprimido da primeira etapa "scavenger") com teor de $\mathrm{Al}_{2} \mathrm{O}_{3}$ aproveitável igual a $25,6 \%$ e recuperações em massa e de alumina aproveitável de, respectivamente, 46,3\% e 92,9\%, com $38,9 \%$ de $\mathrm{Fe}_{2} \mathrm{O}_{3}$ e $0,86 \%$ de $\mathrm{SiO}_{2}$ reativa; e dois rejeitos finais (flotados das duas etapas "cleaner") com os seguintes teores e recuperações de $\mathrm{Al}_{2} \mathrm{O}_{3}$ aproveitável, respectivamente, $1,7 \%$ (I) e $6,8 \%$ (II), $7,1 \%$ (I) e $28,1 \%$ (II). Foi feita uma separação magnética de média intensidade com o concentrado final, resultando em um produto não-magnético com teor de $\mathrm{Al}_{2} \mathrm{O}_{3}$ aproveitável de $49,2 \%$, recuperação em massa de $17,8 \%$, recuperação de $\mathrm{Al}_{2} \mathrm{O}_{3}$ aproveitável de $68,7 \%$, com teores de $11,9 \%$ de $\mathrm{Fe}_{2} \mathrm{O}_{3}$ e $0,76 \%$ de $\mathrm{SiO}_{2}$ reativa. Portanto, com teores dentro das especificações para fabricação de alumina. 
Com o intuito de validar as conclusões do trabalho experimental, uma nova amostragem de minério gnáissico foi feita na usina de beneficiamento de Itamarati de Minas em julho de 2005. As amostras do "underflow" do ciclone de 6" foram pesadas, secas, homogeneizadas e separadas em alíquotas. Foram feitas análise química da amostra de cabeça e por faixa granulométrica, difratometria de raios $\mathrm{X}$, semiquantitativa por espectrometria de fluorescência de raios $X$ e microscopia eletrônica de varredura. As análises químicas indicaram que essa nova amostra, na fração abaixo de $0,21 \mathrm{~mm}(66,4 \%$ da massa total), possui os seguintes teores: $14,1 \%$ de $\mathrm{Al}_{2} \mathrm{O}_{3}$ aproveitável,4\% de $\mathrm{SiO}_{2}$ reativa e $18,1 \%$ de $\mathrm{Fe}_{2} \mathrm{O}_{3}$. Comparando as frações granulométricas da amostra nova com a antiga, observa-se que no geral, os teores de $\mathrm{SiO}_{2}$ total, reativa e insolúvel são um pouco superiores, principalmente na fração mais fina, assim como os teores de $\mathrm{Al}_{2} \mathrm{O}_{3}$ aproveitável. Os teores de $\mathrm{Fe}_{2} \mathrm{O}_{3}$ são ligeiramente inferiores. Estas pequenas diferenças podem ser explicadas pela variabilidade natural nos depósitos de bauxita. A difratometria de raios $\mathrm{X}$ indicou a presença dos seguintes minerais: quartzo $\left(\mathrm{SiO}_{2}\right)$, cristobalita $\left(\mathrm{SiO}_{2}\right)$, gibsita $\left(\mathrm{Al}(\mathrm{OH})_{3}\right)$, ilmenita $\left(\mathrm{FeTiO}_{3}\right)$ e caulinita. A cristobalita é um polimorfismo do quartzo, portanto, flota junto com este. A espectrometria indicou a presença, principalmente, dos seguintes óxidos: $\mathrm{SiO}_{2}(47,8 \%), \mathrm{Al}_{2} \mathrm{O}_{3}(19,7 \%), \mathrm{Fe}_{2} \mathrm{O}_{3}(17,3 \%)$ e $\mathrm{TiO}_{2}(4,4 \%)$. A microscopia mostrou que a amostra é constituída por grãos bem liberados, com presença de grãos mistos e inclusões de alguns minerais.

As alíquotas que seguiram para os ensaios de flotação eram, primeiro, peneiradas em $0,21 \mathrm{~mm}$ para eliminar a fração acima desta malha. Foi feito um experimento de flotação sem retirar a fração abaixo de $0,01 \mathrm{~mm}$, mas os resultados mostraram uma quantidade de sílica reativa muito alta nos produtos e uma baixa recuperação de alumina aproveitável. Daí a necessidade de se fazer a deslamagem.

Com as amostras, abaixo de $0,21 \mathrm{~mm}$ e acima de $0,01 \mathrm{~mm}$, foi feito o último experimento de flotação com recirculação de produtos e nova alimentação para simular um circuito contínuo em bancada. No circuito, com cinco etapas "rougher", "cleaner" e "scavenger" como mostra a figura 18, os deprimidos da etapa "scavenger" são os concentrados e os flotados da etapa "cleaner" são os rejeitos. $O$ concentrado apresentou recuperação em massa de $27,8 \%$ e recuperação de alumina aproveitável de $71,2 \%$, com os seguintes teores: $29,7 \%$ de $\mathrm{Al}_{2} \mathrm{O}_{3}$ aproveitável, $1,4 \%$ de $\mathrm{SiO}_{2}$ reativa, e 33,5\% de $\mathrm{Fe}_{2} \mathrm{O}_{3}$. Após a separação magnética, a recuperação em massa diminui para $13,3 \%$ e a de alumina aproveitável para 
$60,4 \%$, com um pequeno aumento da $\mathrm{SiO}_{2}$ reativa (1,9\%), diminuição de $\mathrm{Fe}_{2} \mathrm{O}_{3}$ para $9,0 \%$ e aumento da $\mathrm{Al}_{2} \mathrm{O}_{3}$ aproveitável para 52,6\%, o maior teor obtido nos experimentos. No geral, os resultados de recuperações foram inferiores aos do ensaio com etapas "cleaner" e "scavenger", sem recirculação de produtos. Essas diferenças podem ocorrer pela variação natural entre os minérios de um mesmo depósito. O concentrado final atende às especificações da bauxita para fabricação de alumina. A observação dos produtos na lupa mostra a diferença visual entre os produtos da flotação: flotado, composto essencialmente por quartzo; deprimido magnético, composto por ilmenita, minerais de coloração mais escura; e deprimido não-magnético composto por gibsita e algumas contaminações, de aparência terrosa. Assim, a flotação reversa da sílica foi seletiva para concentrar a bauxita. Apesar de não ser utilizada industrialmente para concentração da bauxita, a flotação reversa catiônica da sílica é bastante empregada na concentração do minério de ferro.

Com as informações do balanço de massas da usina de beneficiamento de Itamarati de Minas, alimentada a uma taxa de 350 t/h de minério gnáissico com teor de $30 \%$ de alumina aproveitável no ROM, foi feito um novo balanço com os dados do último experimento. Considerando que a recuperação em massa do concentrado de bauxita (DepÑ-MAG) é 13,3\%, que 38,7 t/h saem do UF do ciclone de 6" e que a perda na deslamagem anterior à flotação é de $1 \%$ da massa, tem-se um incremento de 5,1 t/h de concentrado de bauxita com teor de 52,6\% de alumina aproveitável. Isto corresponde a um aumento de 2,7 t/h de alumina aproveitável.

Como a flotação irá diminuir muito a quantidade de rejeitos gerados, já que todos os produtos da flotação são aproveitáveis, deixarão de ser despejados cerca de $38,3 \mathrm{t} / \mathrm{h}$ de rejeitos na barragem. Este valor aproximado foi obtido considerando uma perda em torno de $1 \%$ na deslamagem (fração abaixo de $10 \mu \mathrm{m}$ ) e o aproveitamento da fração acima de $210 \mu \mathrm{m}$, retirada antes da flotação. Em 2001 a usina passou a operar $24 \mathrm{~h} / \mathrm{d}$ e $6 \mathrm{~d} /$ semana, considerando que em um ano ela opere 52 semanas, o total de horas trabalhadas é 7.488 h/ano. Assim, deixarão de ser despejados 286.790 t/ano ou 198.000 m³/ano de rejeitos na barragem. Isto contribui muito para o aumento da vida útil da barragem de contenção de rejeitos, que tem capacidade de $15.000 .000 \mathrm{~m}^{3}$, volume depositado de $3.545 .817 \mathrm{~m}^{3}$ e requer um investimento de US $\$ 4,500,000.00$, além de causar um impacto ambiental significativo. 
A fração abaixo de $10 \mu \mathrm{m}$, a ser despejada na barragem, corresponde a, aproximadamente, 0,4 t/h (2.067 m³/ano) de acordo com o balanço de massas da usina, quantidade muito abaixo do valor atual. As lamas são constituídas, principalmente, de argilo-minerais e, por esta razão, a única utilização possível é na indústria cerâmica, como demonstrado por Chaves (CHAVES, 2006).

É importante ressaltar que esta linha de pesquisa foi estendida à nova usina de Miraí (MASSOLA, 2008), da CBA, que iniciou sua produção em junho de 2008, e os resultados dos ensaios em escala piloto demonstraram a possibilidade de aplicar o processo de flotação reversa da sílica no beneficiamento de finos de bauxita. 


\section{CONCLUSÕES}

Este trabalho mostrou a importância da minimização da eliminação de rejeitos provenientes do tratamento mineral, para diminuir os impactos ambientais e aproveitar melhor os bens minerais, de acordo com o princípio da mineração sustentável.

Foi demonstrada a possibilidade do aproveitamento de um rejeito ("underflow" do ciclone de 6") proveniente do beneficiamento da bauxita gnáissica na unidade de Itamarati de Minas (MG), da CBA, por flotação reversa da sílica.

Os resultados do experimento de dosagem ótima dos reagentes sugerem para o coletor, a dosagem ótima de $300 \mathrm{~g} / \mathrm{t}$ de Flotigam EDA e para o depressor 300 $\mathrm{g} / \mathrm{t}$ de solução de amido a $2 \%$. Lembrando que os experimentos foram todos realizados em pH 10, definido previamente no trabalho de Freitas (2004).

No ensaio de flotação com "cleaner" e "scavenger", utilizando as dosagens ótimas de reagentes, o teor e a recuperação de alumina aproveitável no concentrado, que eram 25,6\% e 92,9\%, respectivamente, passaram a 49,2\% e $68,7 \%$, após a retirada dos contaminantes de ferro e titânio por separação magnética. O aumento de teor mostra a necessidade de se fazer a separação magnética para obter um concentrado de bauxita adequado à produção de alumina.

O experimento de flotação sem deslamagem indica que as lamas (frações finas) são prejudiciais à flotação mecânica de bancada. Portanto, a deslamagem antes da flotação é necessária. A caracterização do minério amostrado em 2005 (amostra 2) mostrou que este possui mais sílica total na amostra de cabeça e nas frações granulométricas mais finas, em comparação com o minério da amostragem de 2004 (amostra 1).

No último experimento de flotação com recirculação de produtos, com o novo minério, o teor e a recuperação de alumina aproveitável no concentrado atingiram $29,7 \%$ e 71,2\%, respectivamente. Os resultados mostram uma queda na recuperação em massa de alumina aproveitável, devido à queda na recuperação em massa do deprimido em relação ao ensaio anterior. Este fato pode ser explicado pela variabilidade natural da bauxita, que ocorre de corpo para corpo e dentro dos próprios corpos minerais. No entanto, após a separação magnética, o teor aumenta 
para $52,6 \%$, o que justifica esta separação, e a recuperação cai para $60,4 \%$. Os demais teores, de sílica e óxido de ferro, estão dentro das especificações da bauxita para produção de alumina.

De acordo com este último experimento e com os dados de produção da usina de Itamarati de Minas para o minério gnáissico, a recuperação em massa do concentrado de bauxita da usina será superior em 2,8\%. Já a recuperação de alumina aproveitável aumentará 3,0\%. Isto significa um incremento de 5,1 t/h de concentrado de bauxita na produção da usina, sendo $2,7 \mathrm{t} / \mathrm{h}$ de alumina aproveitável. Além do mais, deixarão de ser despejados 38,3 t/h (198.000 m³/ano) de rejeitos na barragem, já que todos os rejeitos da flotação são transformados em subprodutos, podendo ser utilizados como corretivo para a fabricação de cimento portland (concentrado de ferro e titânio) e como areia (sílica) para construção civil, para cobertura de estradas e para aterros.

Assim, atingiu-se o objetivo inicial de aproveitar um rejeito de finos de bauxita através da flotação reversa da sílica, gerando um concentrado e dois subprodutos que podem ser aproveitados. Consequentemente, a produção de concentrado de bauxita da usina e a vida útil da barragem de contenção de rejeitos irão aumentar. 


\section{REFERÊNCIAS}

ARAUJO, A.C.; PERES, A.E.C.; VIANA, P.R.M.; OLIVEIRA, J.F. Flotação de minérios de ferro. In: CHAVES, A.P. Flotação: o estado da arte no Brasil. $1^{1}$ ed. São Paulo: Signus Editora, 2006. p. 317-329.

ASSOCIAÇÃO BRASILEIRA DO ALUMÍNIO. História. Disponível em: $<$ http://www.abal.org.br>. Acesso em: 15 out. 2008.

BÁRDOSSY, G.; ALEVA, G.J.J. Lateritic bauxites. Developments in economic geology, 27. Amsterdam; New York: Elsevier, 1990. 624 p.

BERGERMAN, M.G. Produção mais limpa no tratamento de minérios: caso da Companhia Brasileira de Alumínio, Mina de Itamarati de Minas, MG. 2003. 37 p. Monografia (Trabalho de Formatura) - Escola Politécnica, Universidade de São Paulo, São Paulo, 2003.

BITTENCOURT, L.R.M. The recovery of high-purity gibbisite from a brazilian bauxite ore. 1989. 117 p. Thesis (Master of Science) - The University of Utah, Salt Lake City, 1989.

BITTENCOURT, L.R.M.; LIN, C.L.; MILLER, J.D. The flotation recovery of high-purity gibbsite concentrates from a Brazilian bauxite ore. In: LAKSHMANAN, V.I.

Advanced materials applications of mineral and metallurgical processing principles. Littleton: Society for Mining Metallurgical and Exploration, 1990. p. 77-85.

BLEIER, A.; GODDARD, E. D.; KULKARNI, R. D. The structural effects of amine collectors on the flotation of quartz. In: FUERSTENAU, M. C. Flotation: A. M. Gaudin memorial volume. New York: American Institute of Mining, Metallurgical and Petroleum Engineers, 1976. v. 1, p. 117-148.

CARVALHO, A.; BOULANGÉ, B.; MELFI, A. J.; LUCAS, Y. The Cataguases bauxite deposit. In: CARVALHO, A. et al. Braziliam bauxites. São Paulo: USP / FAPESP, 1997. p. $195-208$.

CHAVES, A. P. Emissões e controles na indústria do alumínio. In: Conferencia internacional sobre tecnologias limpias para la indústria minera, VII. Anales. Rio de Janeiro: CYTEC/ALFA/OLAMI, 2006. p. 53-72. 
CHAVES, A. P. Projeto conceitual da instalação de separação densitária. São Paulo: APChaves, Relatório interno, 2000.

CHAVES, A. P.; LEAL FILHO, L. S. Flotação. In: LUZ, A. B. et al. Tratamento de minérios. $3^{\mathrm{a}}$ ed. Rio de Janeiro: CETEM/MCT, 2002. p. 411-446.

CLARIANT. A Clariant na mineração. In: CHAVES, A.P. Flotação: o estado da arte no Brasil. 1를. ed. São Paulo: Signus Editora, 2006. p. 409-421.

CLARIANT. Literatura técnica: Flotigam EDA. São Paulo, 2001. 4 p.

COMMODITY REPORTS: ALUMINIUM 2008. United Kingdom: Mining Journal Online. Disponível em: <http://www.mining-journal.com/>. Acesso em: 12 jul. 2008.

CUNDIFF, W. H. Alumina. In: WEISS, N. L. et al. SME Mineral processing handbook. New York: Society of mining engineers of the American Institute of Mining, Metallurgical and Petroleum Engineers, Inc, 1985. p. 19.1-19.18.

DIAS, E. G. C. S. Avaliação de impacto ambiental de projetos de mineração no Estado de São Paulo: a etapa de acompanhamento. 2001. 283 p. Tese (Doutorado) - Escola Politécnica, Universidade de São Paulo, São Paulo, 2001.

FREITAS, T. G. Análise de viabilidade técnica de aproveitamento do rejeito de bauxita do Departamento de Itamarati de Minas da Companhia Brasileira de alumínio (CBA). 2004. 31 p. Monografia (Trabalho de Formatura) - Escola Politécnica, Universidade de São Paulo, São Paulo, 2004.

GAUDIN, A. M. Flotation. $1^{\text {st }}$ ed. New York: McGraw-Hill, 1932. 552 p.

HURLBUT, C. S. Dana's manual of mineralogy. New York: John Wiley, 1959. p. 317-318.

LIU, G.; ZHONG, H.; HU, Y.; ZHAO, S.; XIA, L. The role of cationic polyacrylamide in the reverse froth flotation of diasporic bauxite. Minerals Engineering, v. 20, p. 11911199, 2007.

MAIA, J. Conceitos fundamentais do tratamento de minerais. In: ENCONTRO NACIONAL DE TRATAMENTO DE MINÉRIOS, 1., 1973, Rio de Janeiro. Anais. Ouro Preto: UFOP, 1973. 
MANSER, R. M. Handbook of silicate flotation. Stevenage: Warren Spring Laboratory, 1975. 206 p.

MARTINS, M. Aspectos estereoquímicos da interação entre apatita e moléculas de amido e sua influência na flotação. 2004. 93 p. Dissertação (Mestrado) Escola Politécnica, Universidade de São Paulo, São Paulo, 2004.

MÁRTIRES, R.A.C. Alumínio. Sumário Mineral 2008. Disponível em:< http://www.dnpm.gov.br/assets/galeriaDocumento/SumarioMineral2008/aluminio.pdf >. Acesso em: 14 nov. 2008.

MASSOLA, C. P. Flotação reversa da bauxita de Miraí, MG. 2008. 85 p.

Dissertação (Mestrado) - Escola Politécnica, Universidade de São Paulo, São Paulo, 2008.

MASSOLA, C.P.; CHAVES, A.P.; LIMA, J.R.B.; ANDRADE, C.F. Separation of silica from bauxite via froth flotation. Minerals Engineering, v. 22, p. 315-318, 2009.

MINERAL COMMODITY SUMMARIES 2008. Washington: U.S. Geological Survey, 2008, Annual. 199 p. Disponível em: <http://minerals.usgs.gov/minerals/pubs/mcs/>. Acesso em: 14 nov. 2008.

NEDER, E.E.; LEAL FILHO, L.S. O uso de aminas graxas e seus derivados na flotação de minérios brasileiros. In: Encontro Nacional de Tratamento de Minérios e Metalurgia Extrativa, XXI., 2005, Natal. XXI Encontro Nacional de Tratamento de Minérios e Metalurgia Extrativa. Natal: UFRN-CEFET/RN, 2005. 1 v., p. 395-404.

OBA, C. A. I. Caracterização dos rejeitos de bauxita de Itamarati e Descoberto. São Paulo: APChaves, Relatório interno, 2000. 62 p.

SALUM, M. J. G. Tratamento de minérios: avanços e desafios tecnológicos. In: CONGRESSO BRASILEIRO DE MINERAÇÃO, 10., 2003, Belo Horizonte. Anais eletrônicos. Belo Horizonte: IBRAM, 2003. 1 CD-ROM.

SAMPAIO, J.A.; ANDRADE, M.C.; DUTRA, A.J.B. Bauxita. In: LUZ, A.B. et al. Rochas e minerais industriais. Rio de Janeiro: CETEM/MCT, 2005. p. 279-303.

SÁNCHEZ, L. E. Avaliação de impacto ambiental: conceitos e métodos. São Paulo: Oficina de Textos, 2006. 495 p. 
SMITH, R. W.; AKHTAR, S. Cationic flotation of oxides and silicates. In: FUERSTENAU, M. C. Flotation: A. M. Gaudin Memorial Volume. New York:

American Institute of Mining, Metallurgical and Petroleum Engineers, 1976. v. 1, p. $87-117$.

SUSLICK, S.B.; MACHADO, I.F.; FERREIRA, D.F. Recursos minerais e sustentabilidade. $2^{a}$ ed. Campinas: Centro de Estudos de Petróleo CEPETRO/UNICAMP, 2005. $246 \mathrm{p}$.

WANG, Y.; HU, Y.; HE, P.; GU, G. Reverse flotation for removal of silicates from diasporic-bauxite. Minerals Engineering, v. 17, p. 63-68, 2004.

XU, Z.; PLITT, V.; LIU, Q. Recent advances in reverse flotation of diasporic ores - A Chinese experience. Minerals Engineering, v. 17, p. 1007-1015, 2004. 


\section{APÊNDICE A - Determinação da dosagem ótima de coletor (fluxogramas)}

T01

$\begin{array}{rc}\text { Coletor - Flotigam EDA }(\mathrm{g} / \mathrm{t}) & 200 \\ \text { Depressor Amido de milho }(\mathrm{g} / \mathrm{t}) & 300 \\ \mathrm{pH} & 10\end{array}$

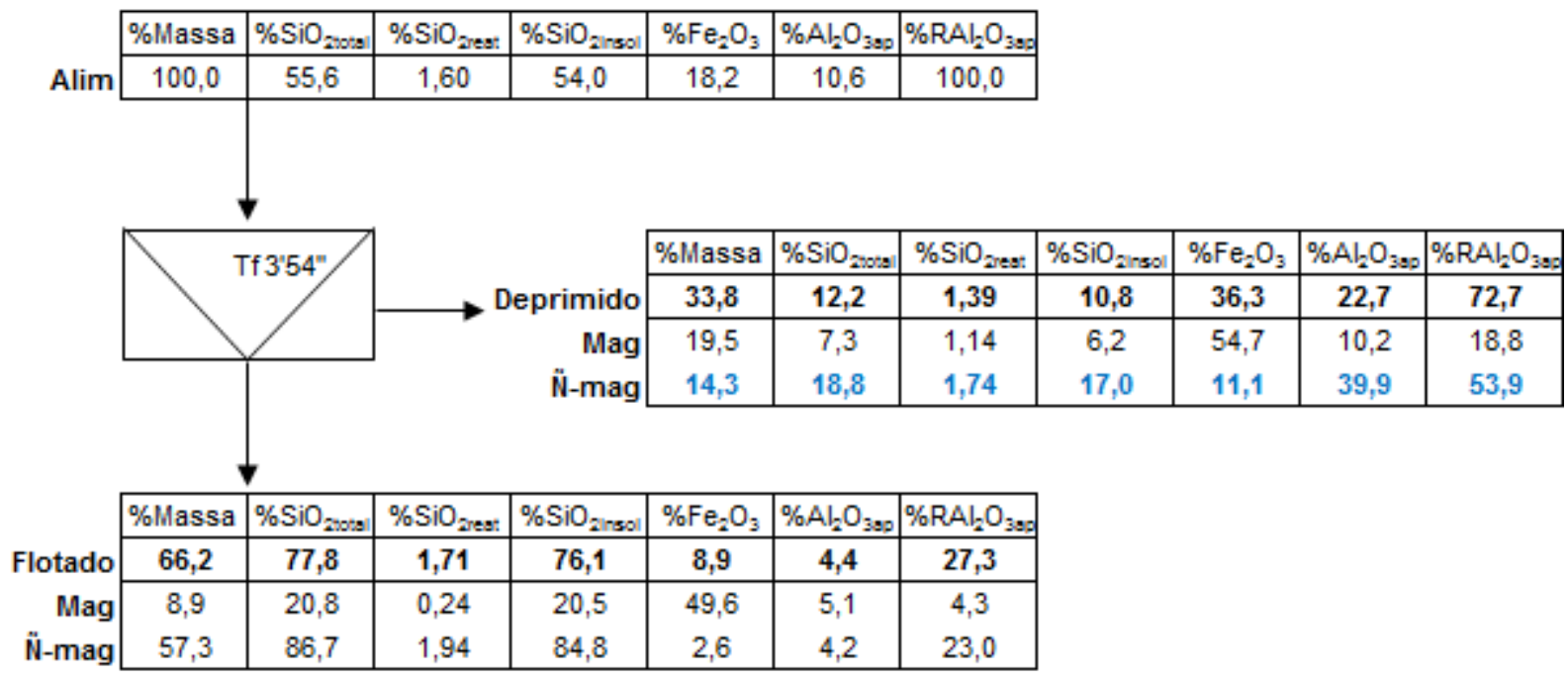

T02

Coletor - Flotigam EDA (g/t) $\quad 250$

Depressor Amido de milho ( $g / t) \quad 300$

pH 10

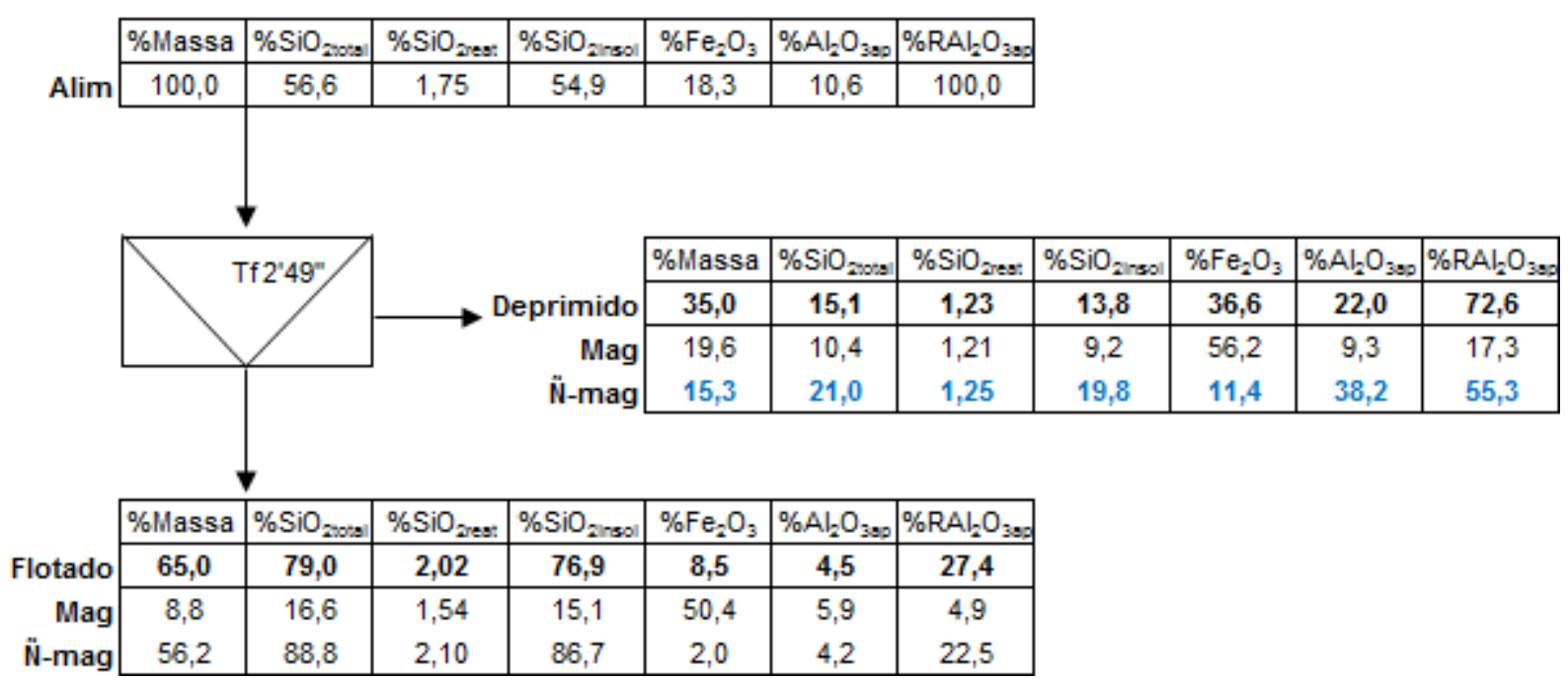




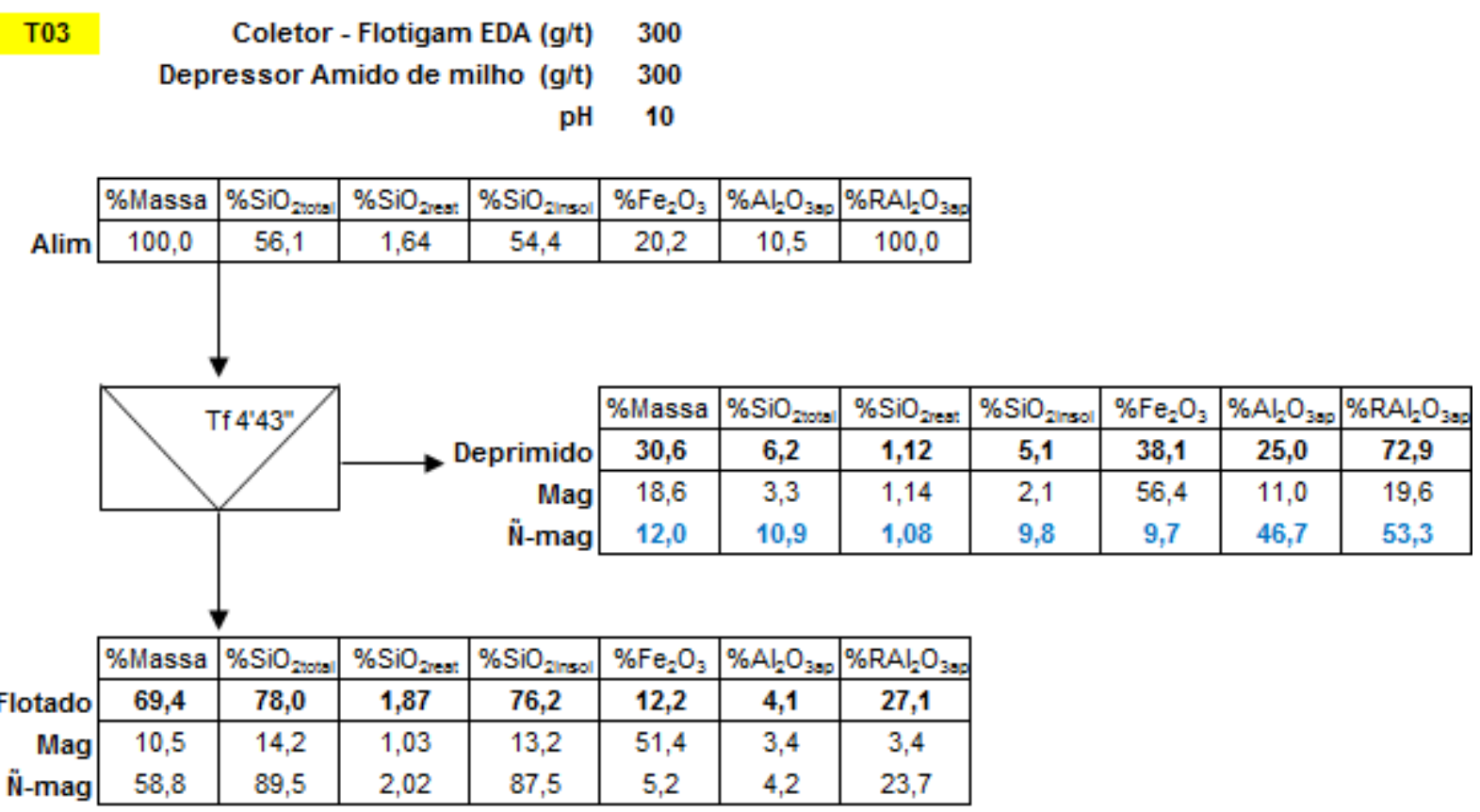

T04 Coletor - Flotigam EDA ( $\mathrm{g} / \mathrm{t}) \quad 350$ Depressor Amido de milho ( $g / t) \quad 300$

$\mathrm{pH} \quad 10$

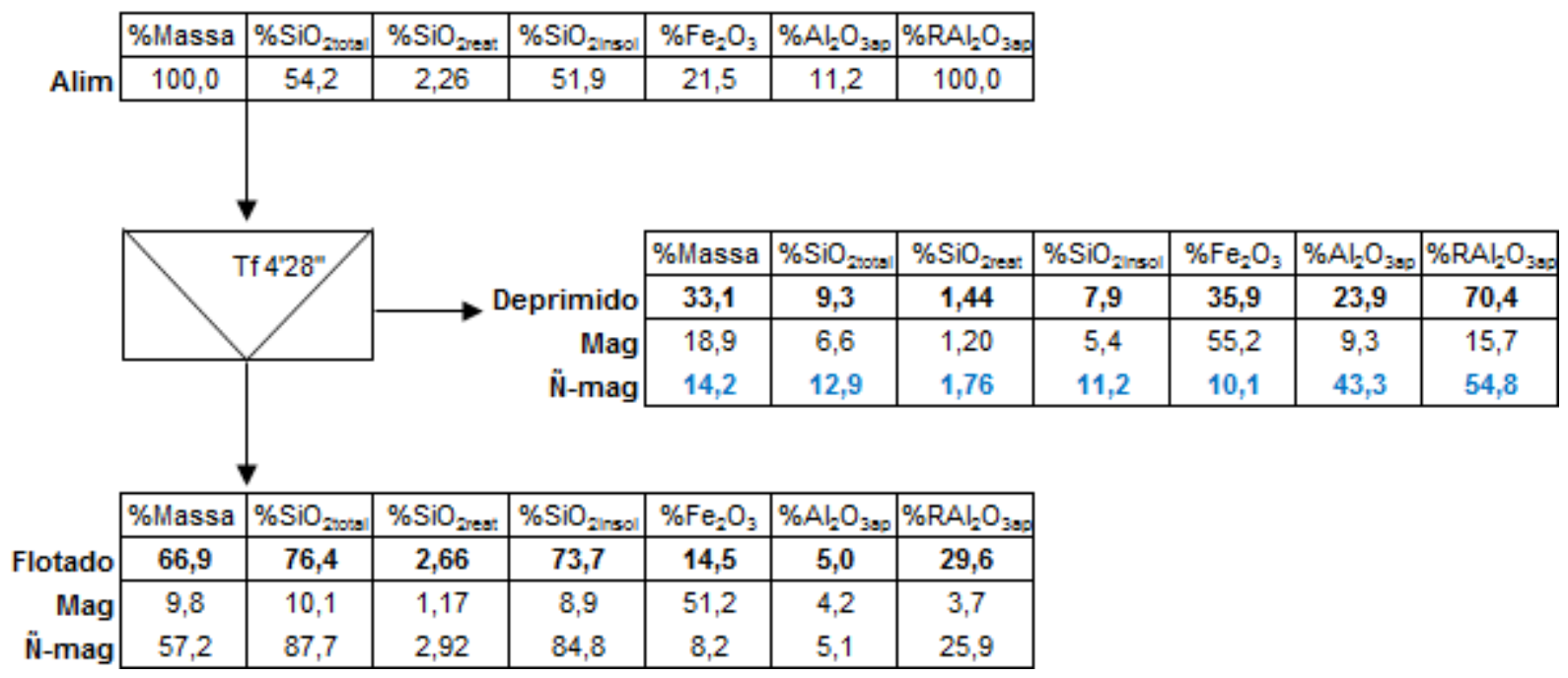




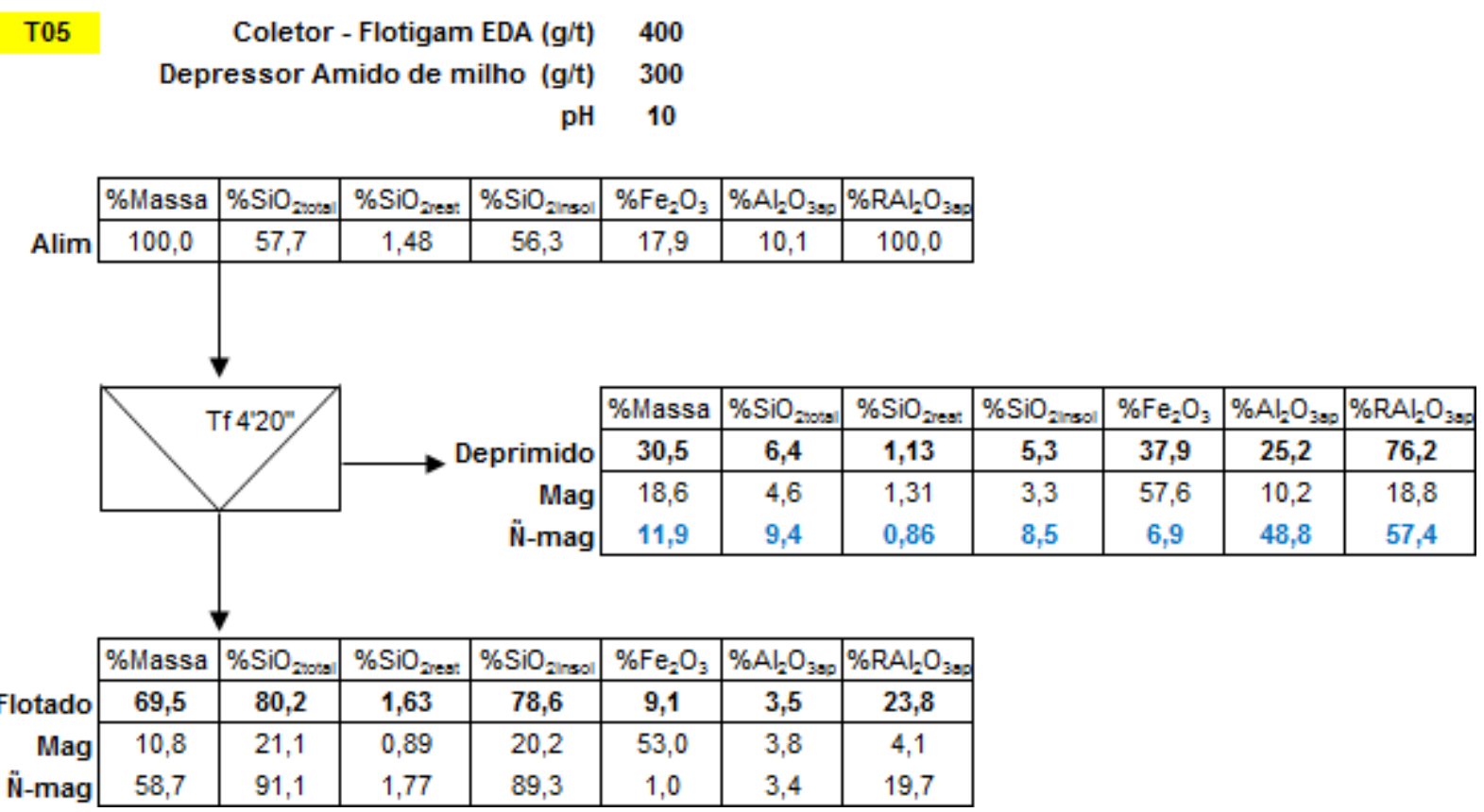




\section{APÊNDICE B - Determinação da dosagem ótima de depressor (fluxogramas)}

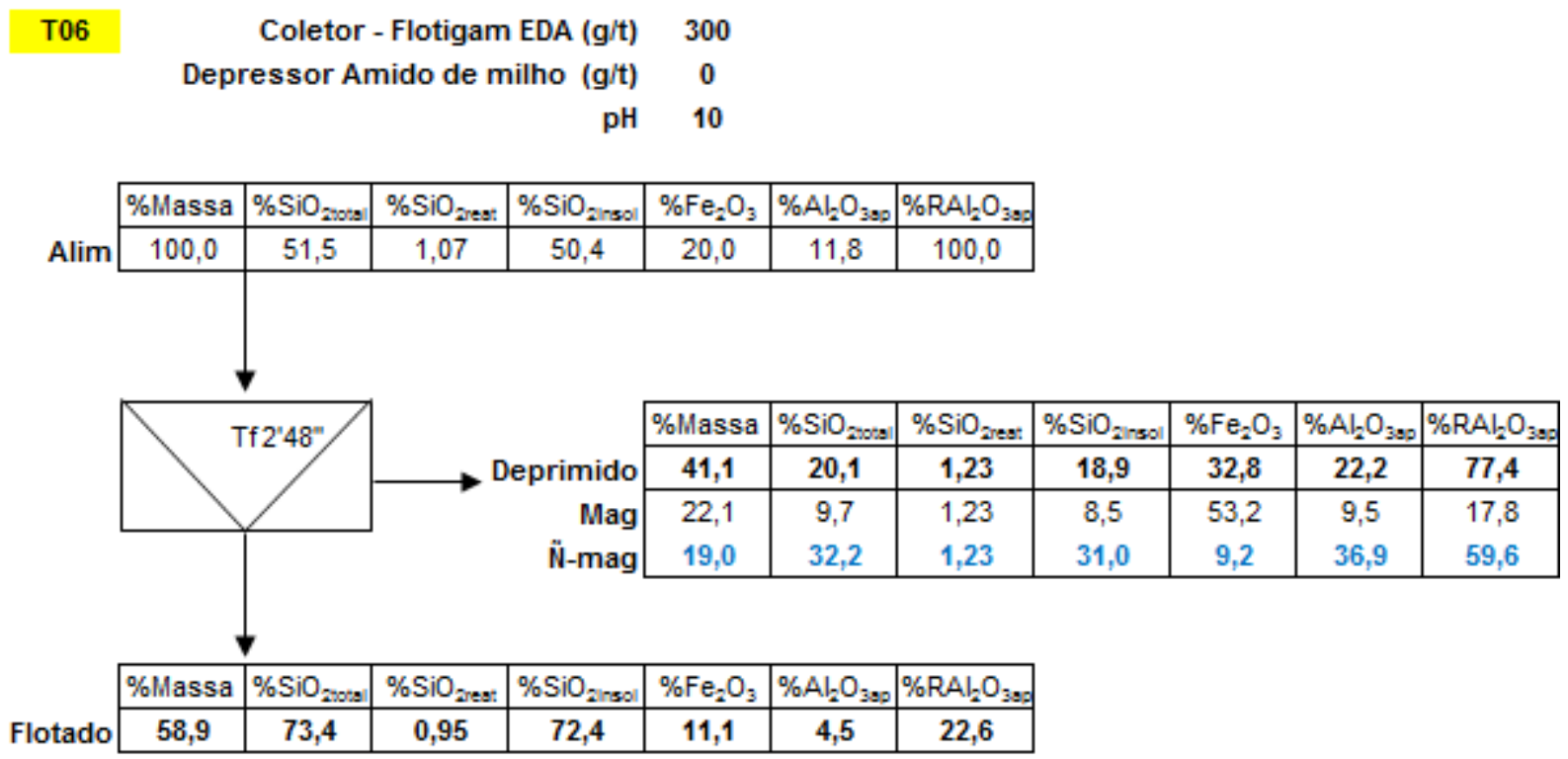



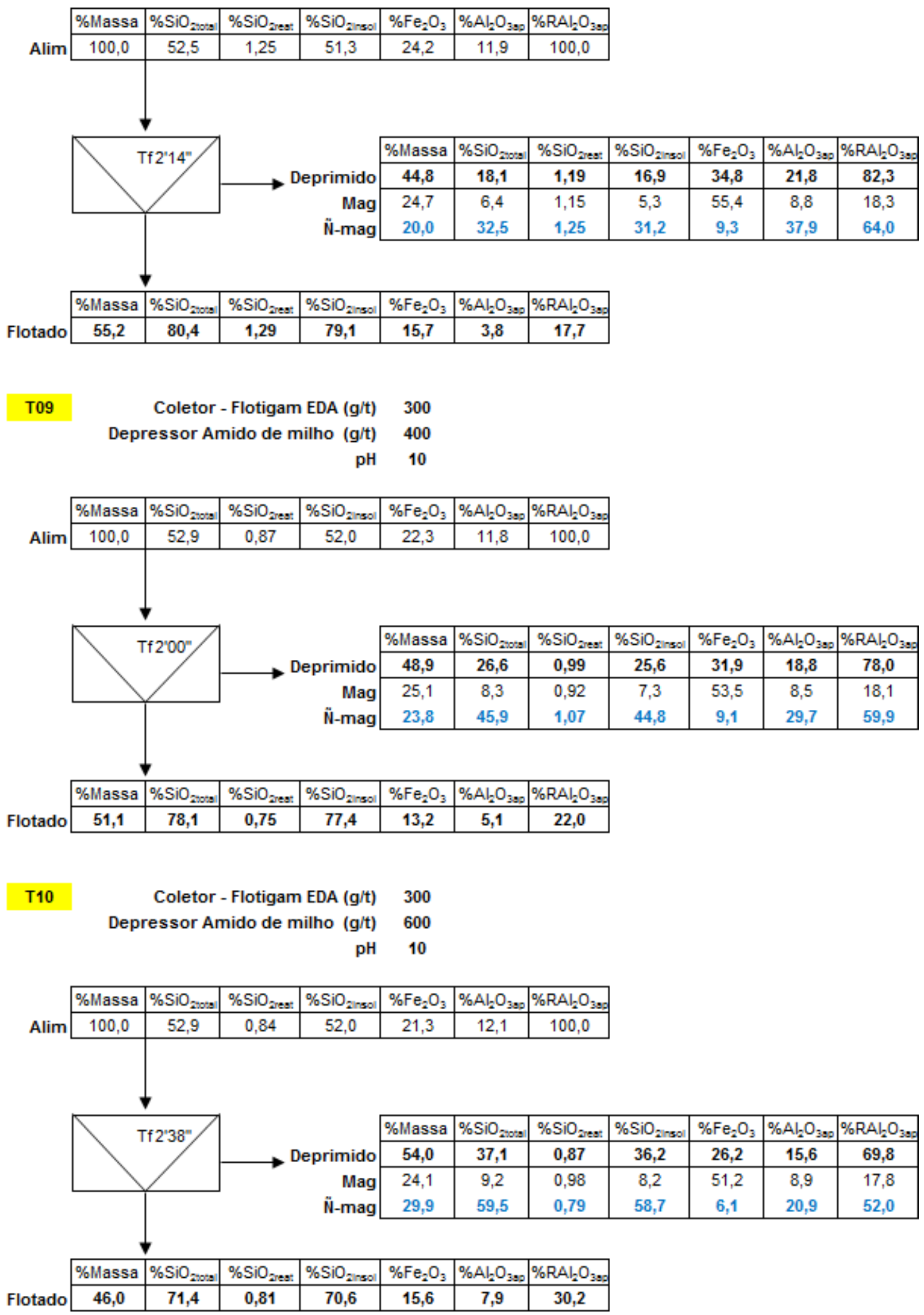


\section{APÊNDICE C - Flotação com "cleaner" e "scavenger" (fluxogramas)}
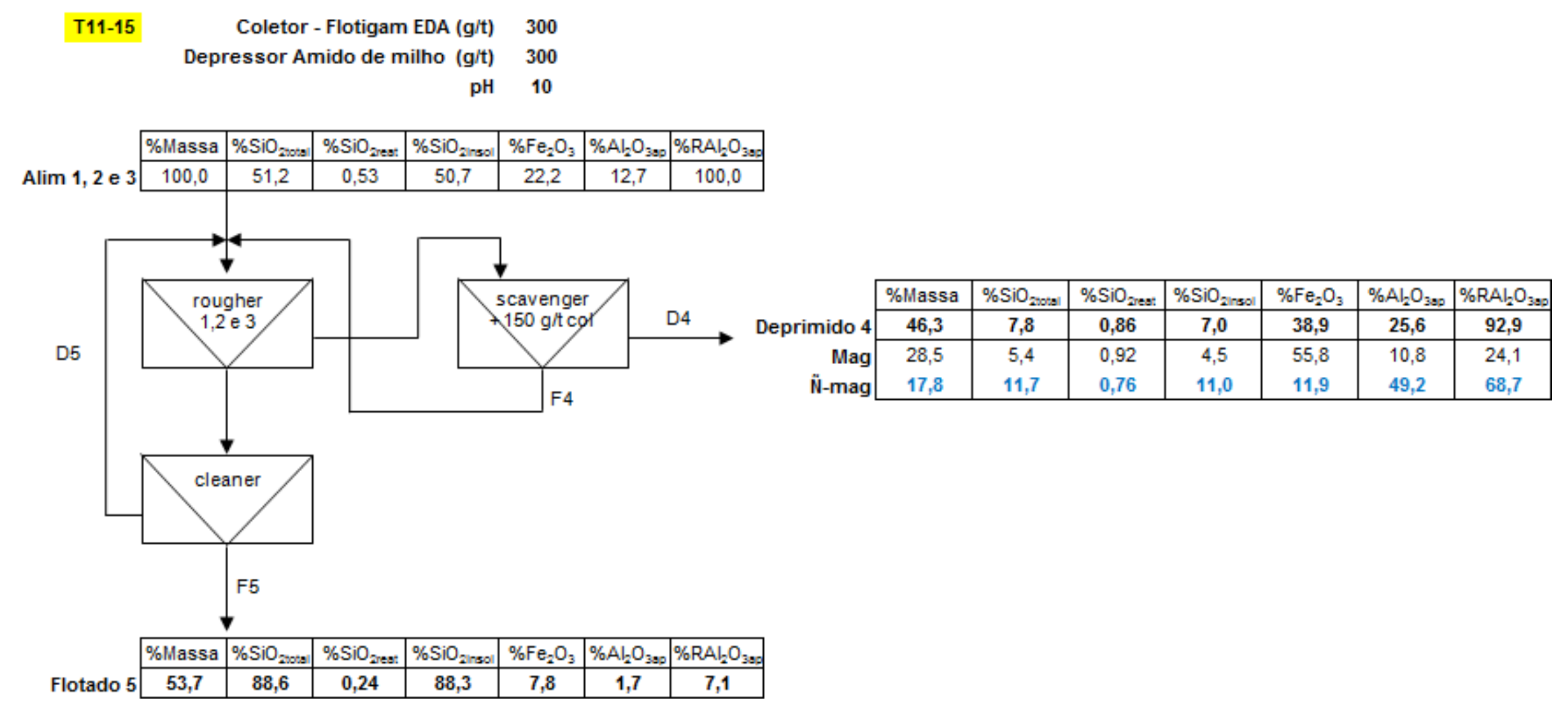


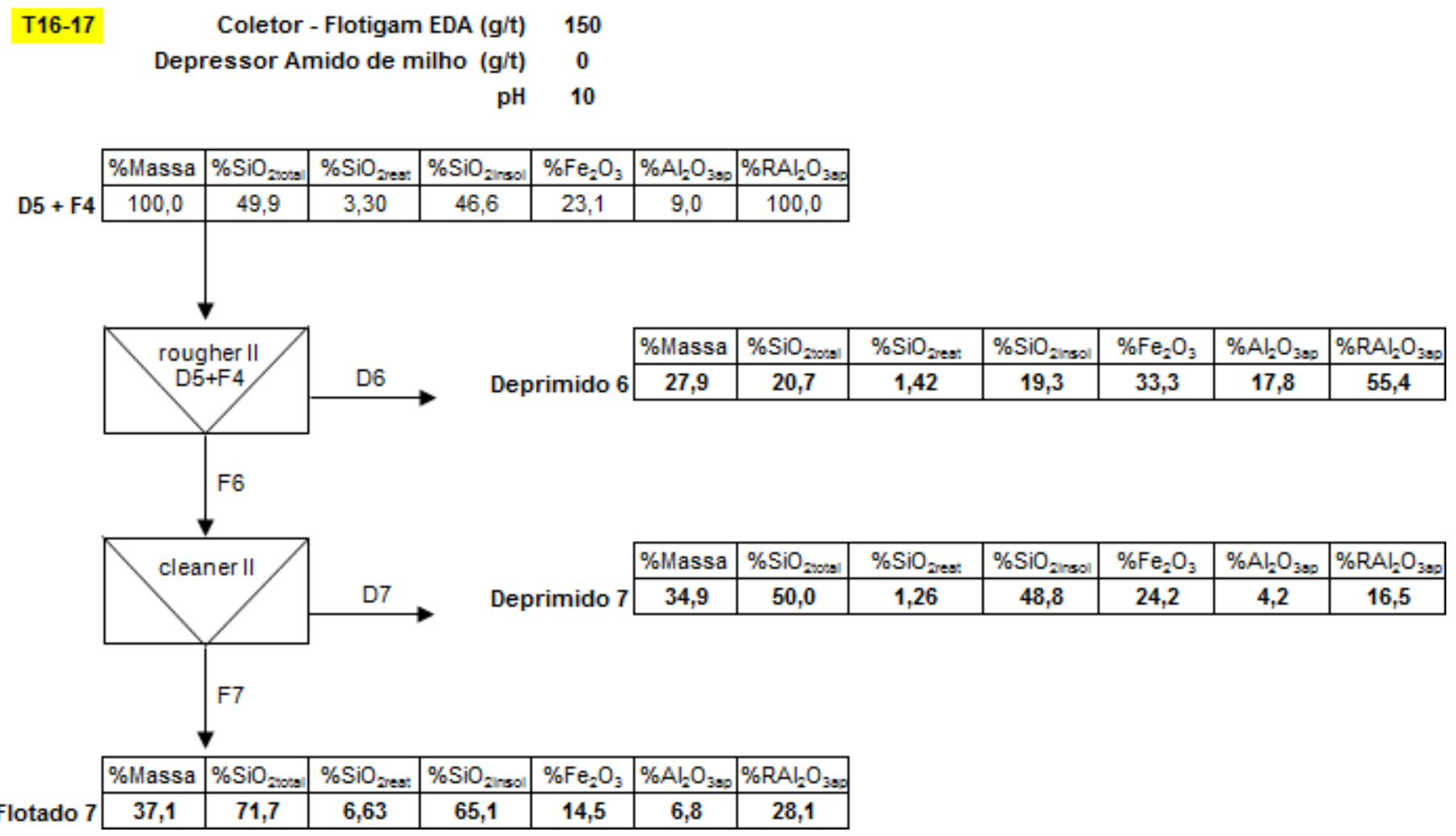




\section{APÊNDICE D - Flotação sem deslamagem (fluxogramas)}
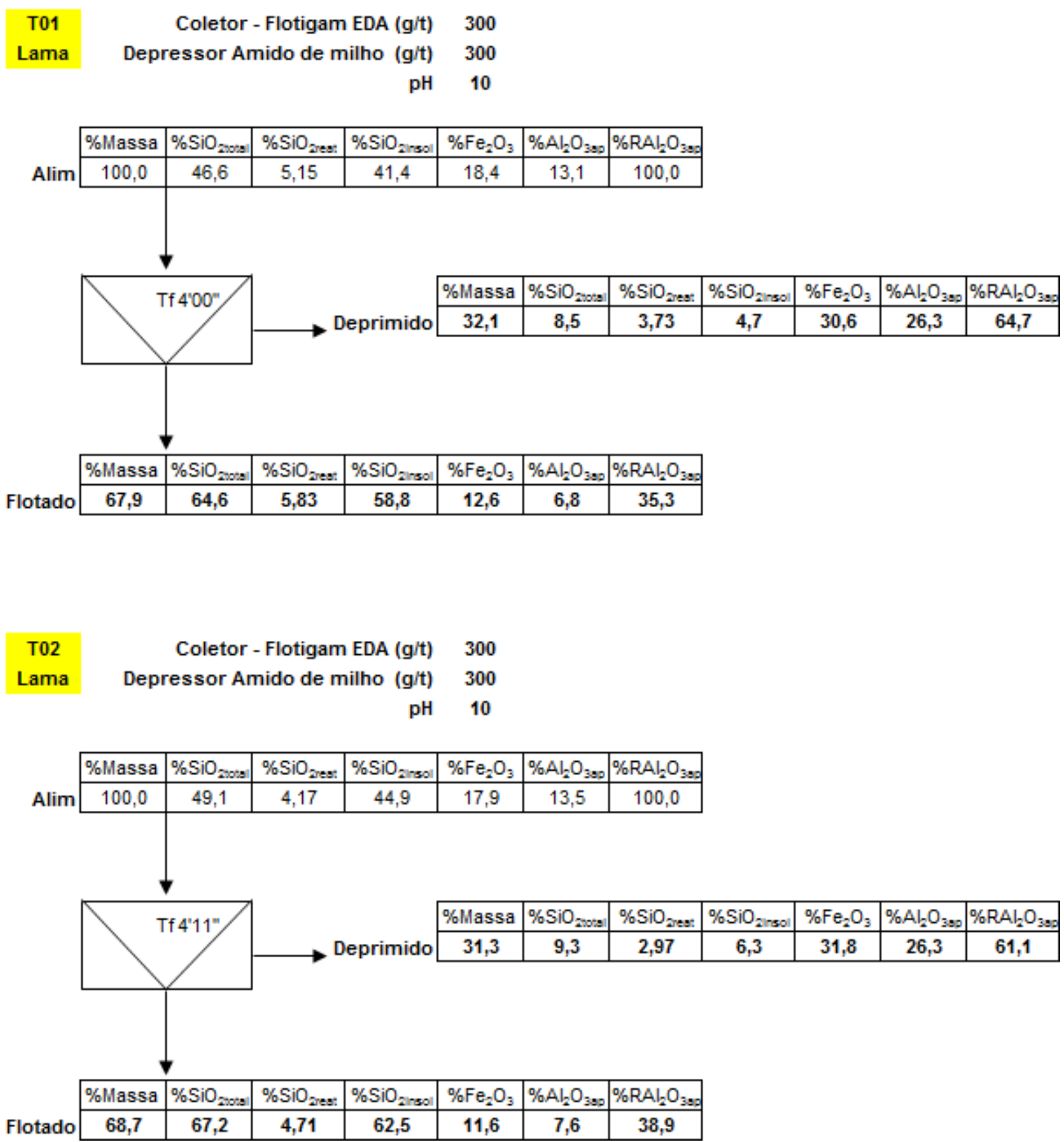
APÊNDICE E - Flotação com recirculação de produtos (fluxograma)

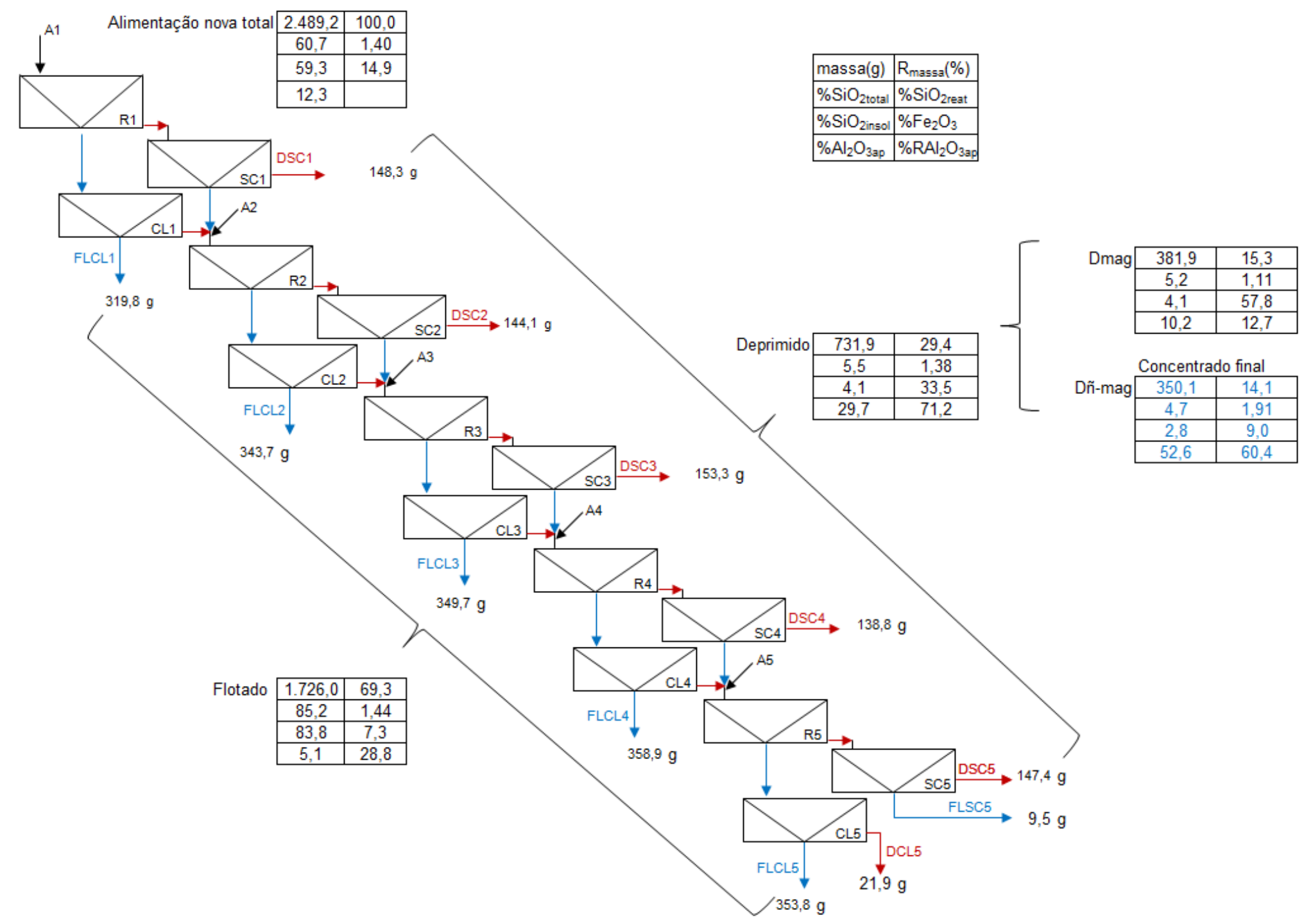




\title{
ANEXO A - Resultado de análise por difratometria de raios $X$
}

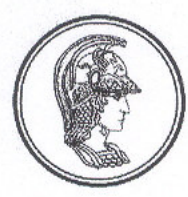

\author{
Escola Politécnica da Universidade de São Paulo \\ Departamento de Engenharia de Minas e de Petróleo \\ Laboratório de Caracterização Tecnológica - LCT \\ Av. Prof. Mello Moraes, 2373 - CEP 05508-030 São Paulo - SP e-mail: lct@poli.usp.br \\ TEL: ( OXX11) 3091-5151 \\ FAX (0XX11) 3815-5785
}

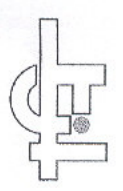

RESULTADO DE ANÁLISE POR DIFRATOMETRIA DE RAIOS X

CERTIFICADO: $117 / 07$

DATA: $11 / 5 / 2007$

CLIENTE: AP CHAVES ASSESSORIA TÉCNICA LTDA

AMOSTRA: CBA Itamarati de Minas UF6" (2005)

IDENT. LCT: 0115-0353.CAF

\section{METODOLOGIA}

$A$ análise foi efetuada através do método do pó, mediante o emprego de difratômetro de raios $\mathrm{X}$, marca PANalytical, modelo X'Pert PRO com detector X'Celerator.

A identificação das fases cristalinas, abaixo discriminadas, foi obtida por comparação do difratograma da amostra com o banco de dados do ICDD - International Centre for Diffraction Data (2003).

\section{RESULTADOS}

Os resultados obtidos estão listados na tabela abaixo:

\begin{tabular}{cllll}
\hline ICDD & Nome do Composto & Fórmula Química & Mineral & Obs \\
\hline $01-078-1253$ & Quartzo & $\mathrm{SiO}_{2}$ & Quartzo & \\
$01-076-0934$ & Cristobalita & $\mathrm{SiO}_{2}$ & Cristobalita & \\
$00-007-0324$ & Gibbsita & $\mathrm{Al}(\mathrm{OH})_{3}$ & Gibbsita \\
$01-075-0519$ & Ilmenita & $\mathrm{FeTiO}_{3}$ & Ilmenita \\
$01-083-0971$ Caulinita & $\mathrm{Al}_{2}\left(\mathrm{Si}_{2} \mathrm{O}_{5}\right)(\mathrm{OH})_{4}$ & Caulinita \\
\hline
\end{tabular}

Nota: $p p=$ possível presença

Em anexo é apresentado o difratograma obtido (cor vermelha), onde são assinaladas as linhas de difração correspondente(s) à(s) fase(s) identificada(s) (cada fase em uma cor distinta).
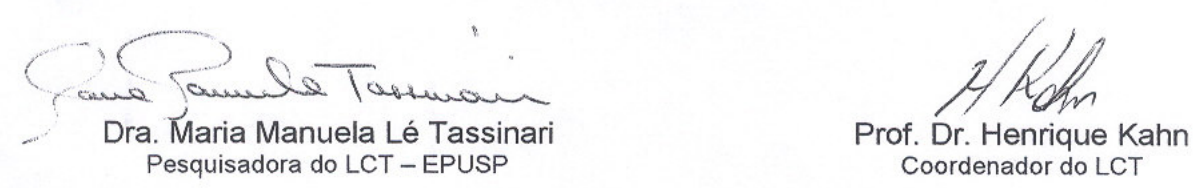
Escola Politécnica da Universidade de São Paulo Departamento de Engenharia de Minas e de Petróleo

Laboratório de Caracterização Tecnológica - LCT Av. Prof. Mello Moraes, 2373 - CEP 05508-030 São Paulo-SP e-mail: Ict@poli.usp.br TEL: ( OXX11) 3091-5151 FAX ( OXX11) 3815-5785

DIFRATOGRAMA DE RAIOS $X$

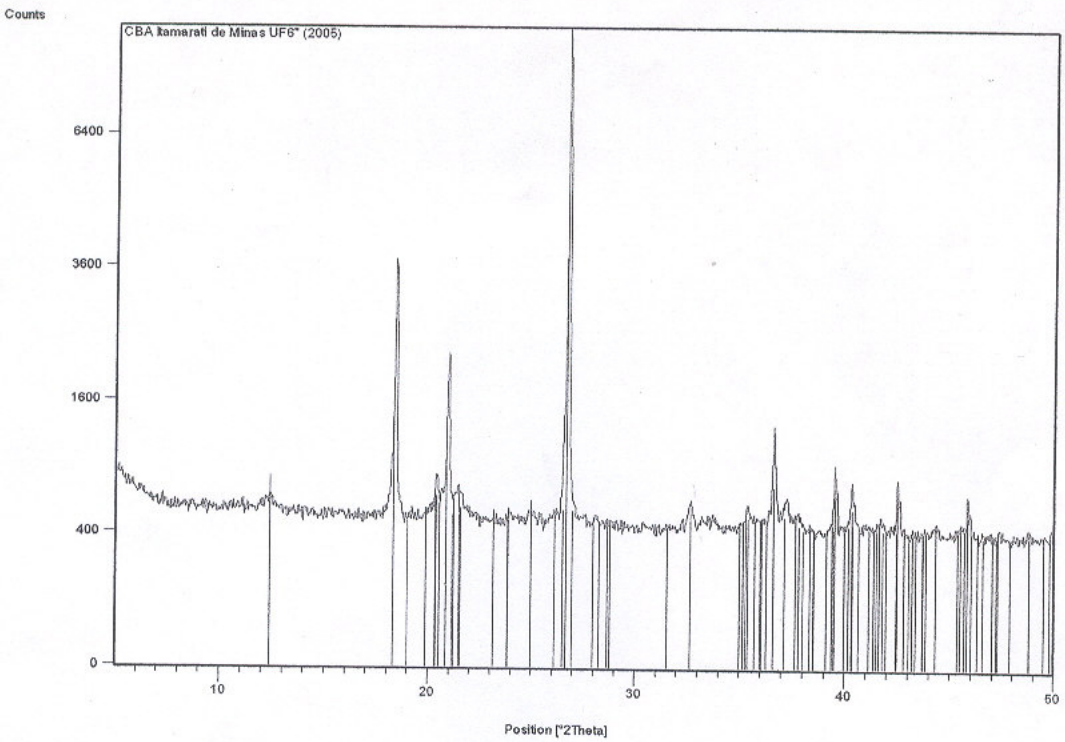

\section{FASES IDENTIFICADAS}

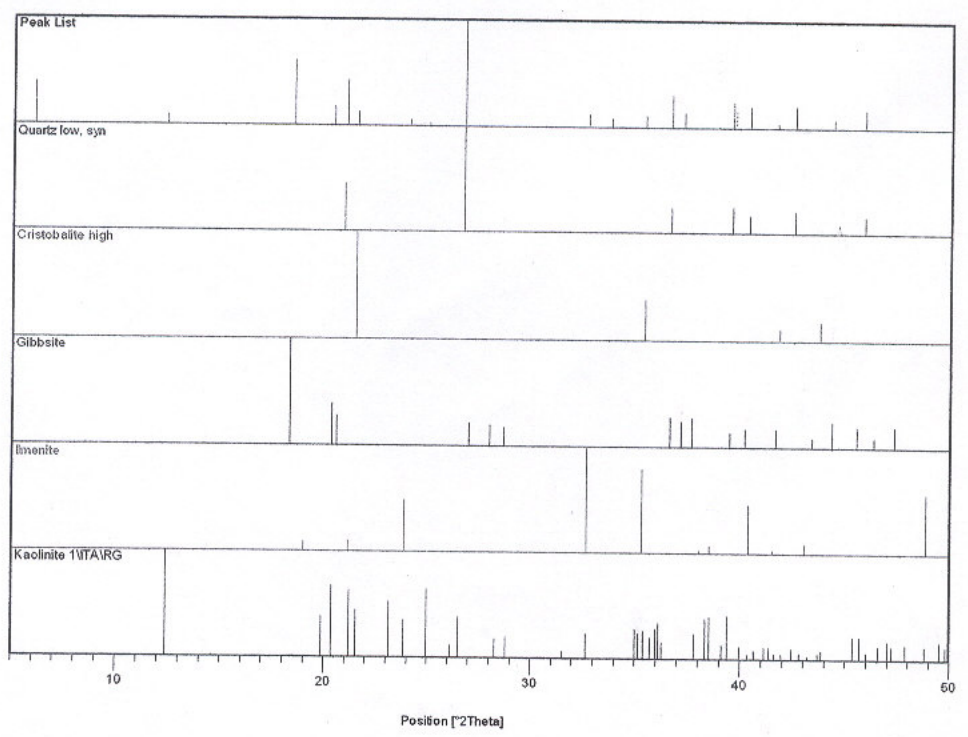




\section{ANEXO B - Resultado de análise por fluorescência de raios $X$}

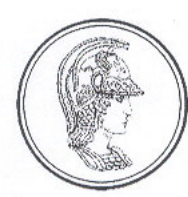

Escola Politécnica da Universidade de São Paulo

Departamento de Engenharia de Minas e de Petróleo

Laboratório de Caracterização Tecnológica - LCT

Av. Prof. Mello Moraes, 2373 - CEP 05508-030 São Paulo-SP e-mail: Ict@poli.usp.br

TEL: $(0 X X 11) 3091-5151 \quad$ FAX $(0 X X 11)$ 3815-5785

\section{RESULTADOS DE ANÁLISE QUÍMICA}

$\begin{array}{lll}\text { CERTIFICADO: } 323 / 07 & \text { REQ. } 405 / 07 & \text { DATA: } 11 / 05 / 07\end{array}$

CLIENTE: AP CHAVES ASSESSORIA TÉCNICA LTDA

TIPO DE ANÁLISE: Semiquantitativa, por espectrometria de fluorescência de raios-X

Resultados em \% de óxidos, normalizados a $100 \%$
\begin{tabular}{|l|c|}
\hline $\mathrm{N}^{\circ} \mathrm{LCT}$ & $2218 / 07$ \\
\hline $\mathrm{Amostra}$ & CBA Itamarati de minas UF 6" (05) \\
\hline $\mathrm{Al}_{2} \mathrm{O}_{3}$ & 19,7 \\
\hline $\mathrm{SiO}_{2}$ & 47,8 \\
\hline $\mathrm{P}_{2} \mathrm{O}_{5}$ & 0,22 \\
\hline $\mathrm{SO}_{3}$ & 0,14 \\
\hline $\mathrm{K}_{2} \mathrm{O}$ & 0,02 \\
\hline $\mathrm{CaO}$ & 0,02 \\
\hline $\mathrm{TiO}_{2}$ & 4,43 \\
\hline $\mathrm{V}_{2} \mathrm{O}_{5}$ & 0,03 \\
\hline $\mathrm{Cr}_{2} \mathrm{O}_{3}$ & 0,09 \\
\hline $\mathrm{MnO}$ & 0,03 \\
\hline $\mathrm{Fe} \mathrm{O}_{3}$ & 17,3 \\
\hline $\mathrm{ZnO}$ & 0,01 \\
\hline $\mathrm{ZrO}_{2}$ & 0,26 \\
\hline $\mathrm{Nb}_{2} \mathrm{O}_{5}$ & 0,01 \\
\hline $\mathrm{PF}$ & 10,0 \\
\hline
\end{tabular}

DADOS OPERACIONAIS:

Análise semiquantitativa sem padrões, de flúor a urânio

$\ll<=$ Traços (menor que $0,01 \%$ ) nd = elemento não detectado $P F=$ Perda ao Fogo a $1050^{\circ} \mathrm{C}$

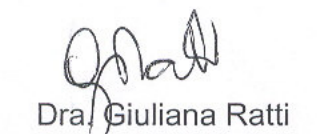

Pesquisadora do LCT - EPUSP

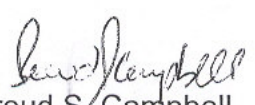

Freud S/Campbell Pesquisador do LCT - EPUSP
Prof. Dr. Henrique Kahn Coordenador do LCT 